\title{
Standards for Tree Improvement in Alberta
}

Alberta Sustainable Resource Development 
Digitized by the Internet Archive in 2016 


\section{Standards for Tree Improvement in Alberta}

Land and Forest Division Alberta Sustainable Resource Development July, 2005 
Publication Number: Ref. T/079

ISBN No. 0-7785-4082-0 (Printed On-line Edition)

ISBN No. 0-7785-4081-2 (Printed Edition)

Printed August 15, 2005

This document can be found on the Alberta Sustainable Resource Development website:

http://www3.gov.ab.ca/srd/forests/fmd/manuals/index.html 


\section{PREAMBLE}

This manual states standards for Tree (primarily Spruce, Pine, Aspen, Poplar) Improvement in Alberta. Use of Genetically Modified Organisms (GMOs) is not approved for reforestation of Provincial Crown land at this time. Federal legislation controls the testing of GMO's, though Alberta may refuse testing on Crown Land if risks are deemed unacceptable.

\section{ACKNOWLEDGEMENTS}

The standards presented in this document were developed through the Alberta Forest Genetics Framework (AFGF) and its consultants and technical task groups. The AFGF is comprised of both forest industry and government staff. Alberta Sustainable Resource Development wishes to thank the following individuals for their dedication and diligence in developing these standards.

Harry Archibald
Colin Bamsey
Leonard Barnhardt
Peter Blake
Lee Charleson
Daniel Chicoine
John Edwards
Dave Fox
Tim Gylander
Christine Hansen
Gary Harmata
Anita Jenkins
Sally John
Chuck Kaiser
Don Lester
Hugh Lougheed

Harry Archibald

Colin Bamsey

Leonard Barnhardt

Peter Blake

Lee Charleson

Daniel Chicoine

John Edwards

Dave Fox

Tim Gylande

Christine Hansen

Sally John

Chuck Kaiser

Hugh Lougheed
Kent MacDonald

Bruce Macmillan

Scott Milligan

Dave Morgan

Florance Niemi

Donna Palamarek

Daryl Price

Fred Radersma

Diane Renaud

Doug Sklar

Cliff Smith

Harry Stelfox

Barb Thomas

Pat Wearmouth

Ken Yackimec 


\section{Table of Contents}

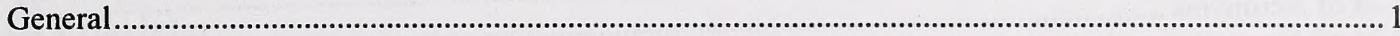

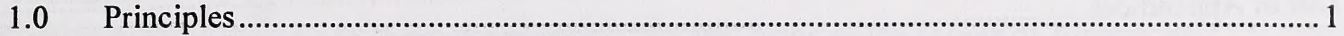

2.0 Development and Review of the Standards......................................................................... 1

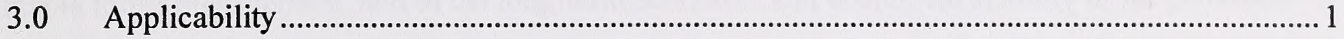

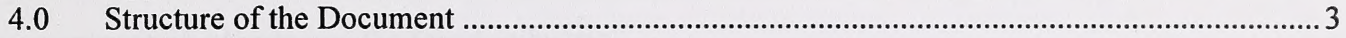

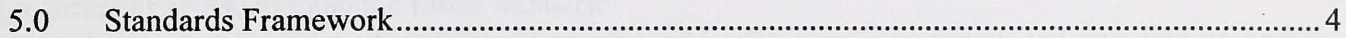

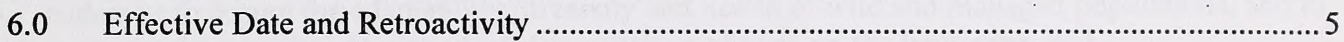

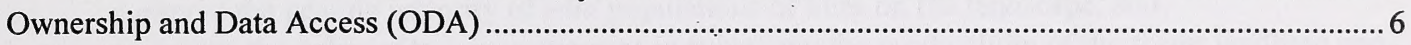

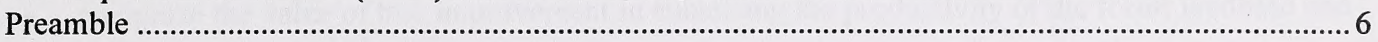

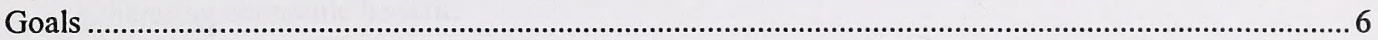

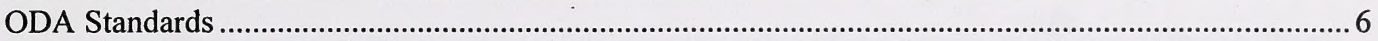

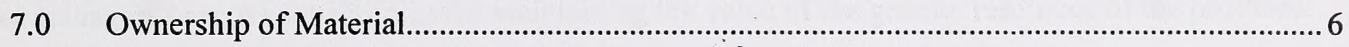

8.0 Management of Intellectual Property .............................................................................

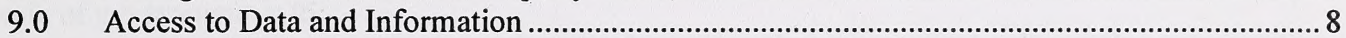

Material Collection, Handling, Registration and Storage (MCHRS) ………………….......................... 9

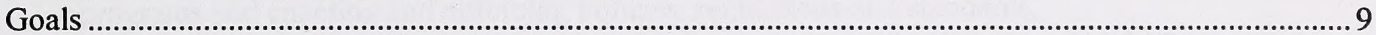

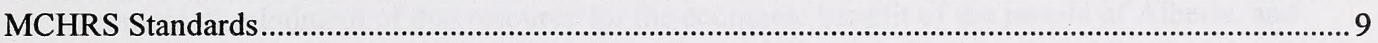

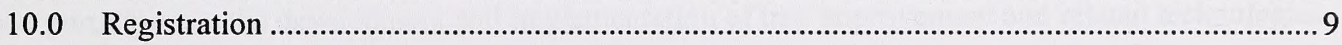

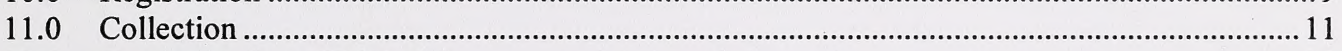

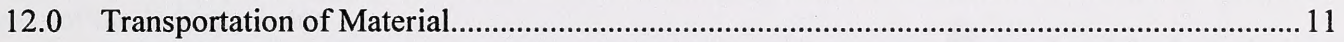

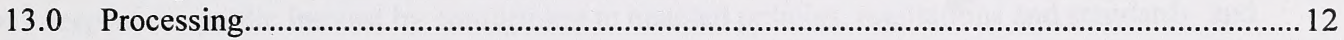

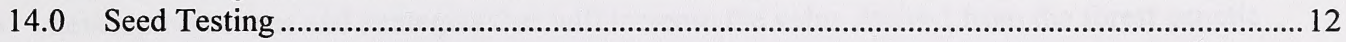

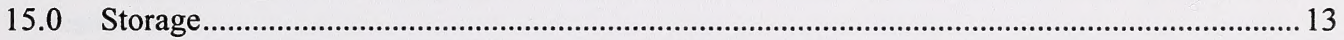

16.0 Excess Seed, Seedlings and Vegetative Material .................................................................13

17.0 Retention of Material for Ex Situ Conservation ............................................................... 13

Green Area Deployment (GAD) ..................................................................................................... 14

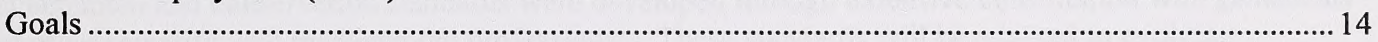

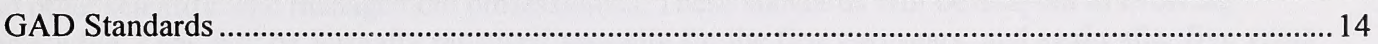

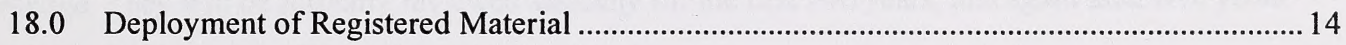

19.0 Deployment of Unregistered Material................................................................................. 16

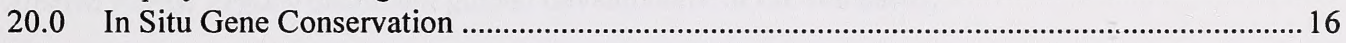

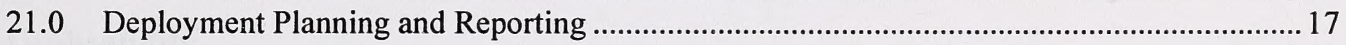

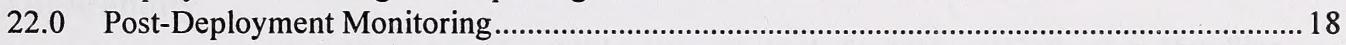

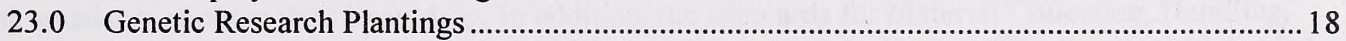

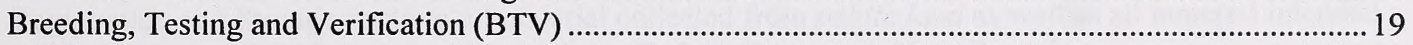

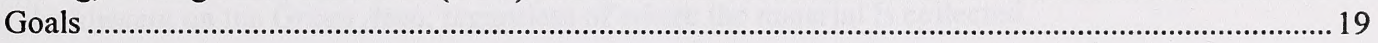

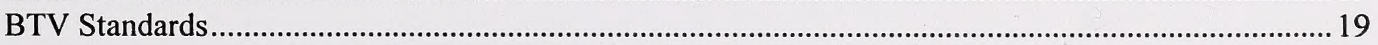

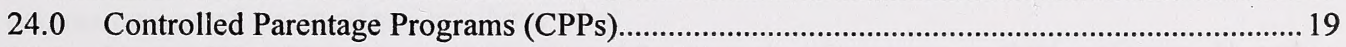

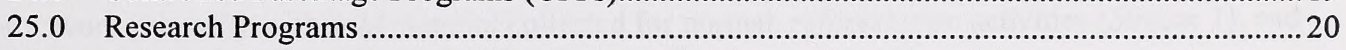

26.0 Genotype Information and Pedigree Records....................................................................22

27.0 Field Test Data Handling, Storage and Access .............................................................20

28.0 Delineation and Revision of Breeding Regions, Deployment Zones and Species-Specific

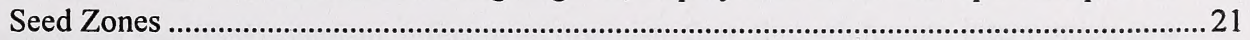

29.0 Ex Situ Conservation of Native Species...................................................................2

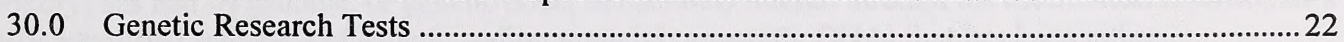

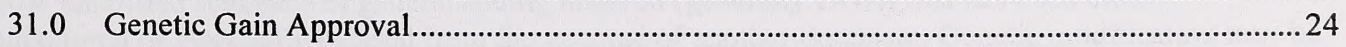

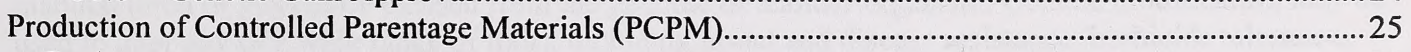

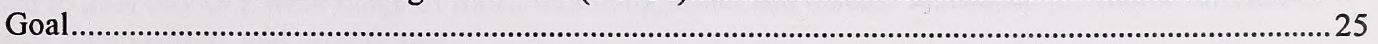

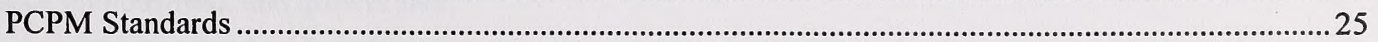

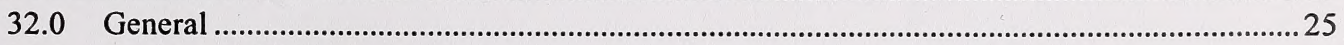

33.0 Seed Material Production ....................................................................................... 26 


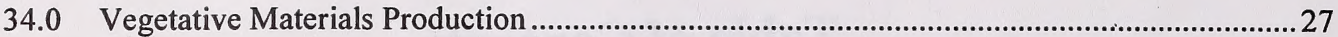

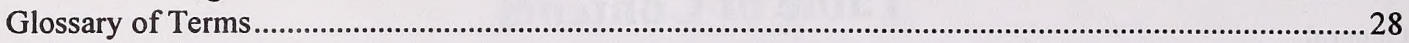

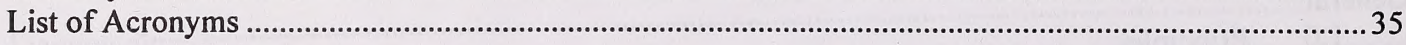

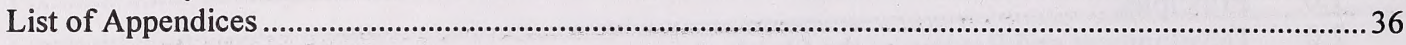




\section{GENERAL}

\subsection{Principles}

The forest genetic resources of Alberta are crucial to the well being of the people of Alberta, to sustainable forest management, and to the long-term economic and ecological stability of the province.

The government of Alberta and the forest industry:

- endeavor to ensure the adaptability, diversity and health of wild and managed populations, and to conserve the genetic integrity of wild populations of trees on the landscape, and

- recognize the value of tree improvement in enhancing the productivity of the forest landbase and generating economic benefit.

Forest managers have responsibilities for maintaining the value of the genetic resources of the province.

The role of government is to:

- protect the public interest and conserve the forest genetic resource by implementing conservation programs and enacting and enforcing policies, regulations and standards,

- promote development of that resource for the economic benefit of the people of Alberta, and

- participate in the development and implementation of tree improvement and related technologies.

The role of the industry is to:

- respect the public interest by conforming to enacted policies, regulations and standards, and

- develop objectives and strategies that will increase the value derived from the forest genetic resource.

\subsection{Development and Review of the Standards}

Management and conservation standards were developed through extensive consultation with geneticists and other scientific and management professionals. These standards will be adapted to evolving knowledge. They will be formally reviewed annually for the first two years, and again after five years.

The Alberta Forest Legacy document guided development of the standards.

\subsection{Applicability}

These standards apply to the Green Area. In addition, the standards for Material Collection, Handling, Registration and Storage apply to all material collected from public land as well as all material intended for deployment on the Green Area, regardless of where the material is collected.

The two main users of the standards are those who:

- $\quad$ work primarily with wild material collected for normal reforestation activities (Stream 1), and

- have controlled parentage programs (Stream 2).

\section{Genetically Modified Organisms (GMO's)}

GMO, or genetically modified organism, refers to an organism that, through human intervention in a laboratory, has had its genome, or genetic code, deliberately altered through the mechanical insertion of a specific identified sequence of genetic coding material (generally DNA) that has been either manufactured or physically excised from the genome of another organism. Genetic modification may be used to alter any of a wide range of traits, including insect and disease resistance, herbicide tolerance, tissue composition, and growth rate. 
Though it is recognized that GMO tree material has a theoretical potential for reforestation, the performance and impacts on the forest ecosystem are poorly understood. In view of the potential risks associated with reforestation with GMO trees, and in accordance with the current position of the Alberta Forest Genetics Council, GMOs are not approved for use on Crown land in Alberta at this time. The federal government has jurisdiction over testing and use of GMO's in Canada. As such, proponents should contact the appropriate federal department prior to undertaking a program of testing of GMO's. If federal approval for testing of GMO's is granted, this manual outlines additional technical requirements for review, testing, and research from a provincial perspective.

\section{Submission and Approval of Documents}

Plans and forms that are required to be submitted to the Department of Sustainable Resource Development (hereinafter referred to as "the Department") as specified in the standards and appendices will receive one of four responses:

1. Approve

2. Approve with conditions

3. Requires additional information

4. Reject with reasons 


\subsection{Structure of the Document}

Following this General information section are five sections containing goals and standards. Goal statements describe the intent and scope within each area. Standards are the specific results that must be attained, or in some cases specific procedures that must be followed.

The five sections are:

- Ownership and Data Access (ODA),

- Material Collection, Handling, Registration and Storage (MCHRS),

- Green Area Deployment (GAD),

- Breeding, Testing and Verification (BTV), and

- Production of Controlled Parentage Materials (PCPM).

This document also contains a glossary, a list of acronyms and numerous appendices (tables, forms and other supplements to the standards). The glossary provides definitions of terms specific to their usage in this policy.

Two notes about the format of this document:

1. To help separate which standards apply to each of the two streams of material, a double-lined box has been placed around standards that apply exclusively to the controlled parentage programs (see Figure 1, Stream 2) or research programs. Standards appearing outside the box may apply to both streams of material.

2. Terms found in the glossary appear in italics in the text to indicate that the use of the term has been defined. 


\subsection{Standards Framework}

Figure 1 below illustrates a functional arrangement of the components of the Standards for Tree Improvement in Alberta. Stream 1 material refers to the adapted seed or vegetative material collected from wild or artificially regenerated stands of native species. Stream 2 material is that which results from a controlled parentage program.

Figure 1: Schematic Representation of Paths to Deployment

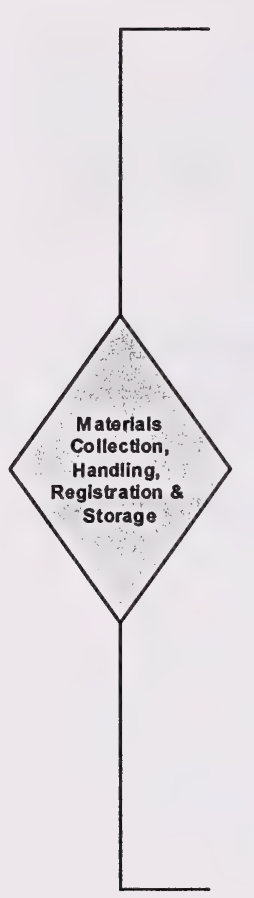

Stream 1

Materials

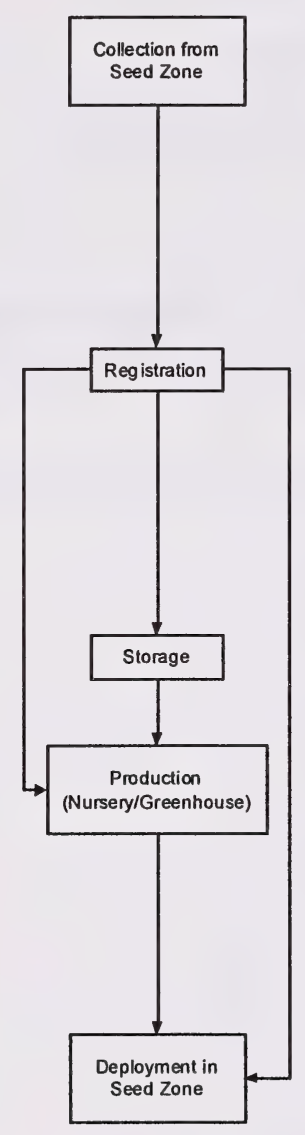

Stream 21

Materials

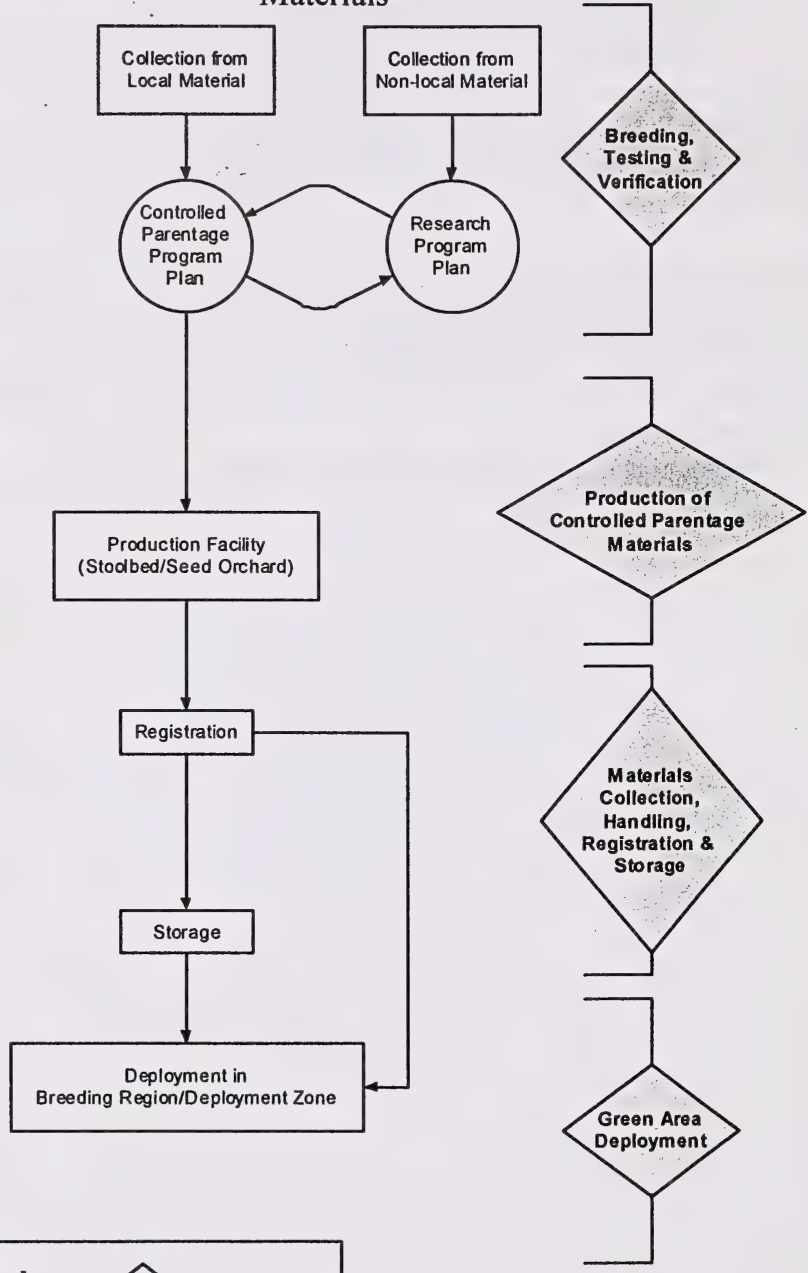

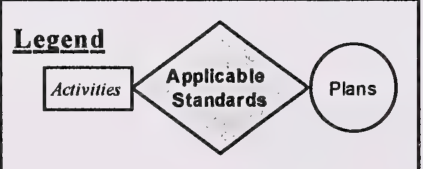

${ }^{1}$ See Appendix 1. 


\subsection{Effective Date and Retroactivity}

These standards are enabled through Timber Management Regulation 144.2 and are effective as of May 01, 2003.

Controlled Parentage and Research Programs that already existed or were under development prior to the effective date will be implemented or upgraded to the new standards through discussion with the Department and the proponent(s). The intent is to capitalize on work in progress while phasing in new standards. 


\section{OWNERSHIP AND DATA ACCESS (ODA)}

\section{Preamble}

The Department has stewardship responsibility for the management of forest genetic resources on public land in Alberta.

The Department, the forest industry, research organizations and tree improvement cooperatives:

- undertake research, conservation, tree improvement and breeding programs jointly or individually, and

- are involved in the collection and deployment of genetically improved trees on public land in Alberta.

As tree improvement programs in the province mature, information will accrue on the performance of genetically improved material. The value of such material, and ownership issues, will become of greater . importance to government and industry. It is also possible that forest material collected from Alberta public land could be utilized for commercial purposes other than fibre production in Alberta. In such instances, benefits to the province must be retained.

\section{Goals}

The goals of this section are to:

- establish ownership and access rights to forest genetic resources, and

- state the Department's requirements for access to data on genetically improved forest material to ensure stewardship of Alberta's forested public land.

If these standards conflict with copyright, patent and/or intellectual property laws, or other federal laws, such legislation would supersede these standards.

\section{ODA Standards}

\subsection{Ownership of Material}

Trees and tree material (physical tree material) on public land are the property of the province. This includes source materials (e.g. pollen, seed, graft materials and vegetative propagules) that have potential for collection through reforestation, and genetic improvement activities. Provincial ownership of material applies regardless of deployment method (natural regeneration, planting, seeding, etc.).

Once authorized by the province through licenses, permits or otherwise, an organization or person(s) owns the trees that have been harvested or other physical material that is collected from public land for the purpose of tree improvement. This ownership right remains until the material is deployed back on to public land, at which time the right transfers to the province.

Some exceptions apply:

- The province reserves the right to retain some collected material for conservation or research purposes. (See Standards 17.0, 29.2, 29.3 and 29.4 for more detail). Such material may be shared with research agencies, but the province will inform those recipients that they cannot distribute material or genotype-specific information on the material. The intent is to encourage use of material for knowledge creation and research, while establishing limits on the distribution of material.

- The province may reserve the right to genotypes and intellectual property wholly or in part developed from forest material collected from Alberta public land when such material is utilized for commercial means. This is outlined in more detail in the next section of this document, "Management of Intellectual Property." 
- Forest Management Agreement (FMA) holders have ownership rights to timber on land subject to an FMA and are entitled to compensation for any damages to timber or improvements they have created (such as genetically improved material that has been deployed on public land).

\subsection{Management of Intellectual Property}

For the purpose of these standards, intellectual property (IP) is considered to be all genetic information that is attributable to specific tree material and associated genotypes, and associated rights to take out a patent on such genotypes. IP resulting from forest genetics and tree improvement research and development projects will be shared between the province, forest company, research organization and/or tree improvement cooperative in accordance with the.following principles.

a) The province recognizes that ownership of IP rights should be based on the degree of effort by parties involved in a breeding or research program in which the province is a cooperator. Effort is generally considered to be financial investment, but may include in-kind contributions such as, but not limited to, facility use, provision of material and scientific support for a specific breeding program. The greater the level of effort, the greater should be the rights to IP. Respective rights to intellectual property should be defined in an agreement between the province and other members of the cooperative.

b) The province will endeavor to retain benefits in the form of revenue whenever material from public land is utilized for commercial means. However, the province will not seek to obtain revenue when material is used for the deployment or strengthening of tree improvement programs in Alberta. Exchanges of material between Alberta and other jurisdictions will generally not be considered for royalties, as such exchanges benefit the province and provincial tree improvement.

\section{Implementation}

For existing and future tree improvement cooperatives involving the province, the province will endeavor to establish agreements that define the respective intellectual property rights of all parties.

For collections of material by parties who do not hold timber dispositions and associated reforestation obligations in Alberta, a Temporary Field Authority (TFA) and collection plan is required as per Standards 11.1.3 and 11.1.4. A condition may be placed on such TFA authorizations stating that the province will retain all intellectual property rights to material collected, unless otherwise defined in an agreement.

The province will endeavor to define commercialization arrangements by way of an agreement at the earliest opportunity, wherever possible. The province may also directly charge a collection fee or royalty on material collected from public land when material is for commercial ventures (i.e. sale of genetically improved material and associated information) that are unrelated to tree improvement or are outside Alberta. 


\section{Rights Authorizations}

The owner of material and intellectual property may authorize another to exercise the owner's rights by way of agreement. The types of rights that might be addressed are material use rights, breeding rights or commercial sales rights. For example, other provinces in Canada have utilized an agreement called a material transfer agreement to specify such rights.

Such agreements may be required between the Department and any other entity - industrial, academic or research - involved in tree improvement activities in Alberta, nationally or internationally. Some situations where these agreements may apply are:

- where a third party wishes to use materials and associated genotypes from a tree improvement program involving the Department or public land for propagation or further breeding for commercial or profit objectives, and

- where any member of a cooperative involving the Department wishes to use material and associated genotypes for propagation or further breeding outside the cooperative(s) where they are participants.

\subsection{Access to Data and Information}

The Department will have access to data and information pertaining to improved stock and/or research and breeding programs. This access is required because of the Department's stewardship responsibility to monitor for diversity and adaptation of materials to be deployed on forested public land. Specific data needs will be outlined in plan submission and reporting requirements as determined in other sections of this document.

All information provided to government, or in the custody or control of government, can be potentially disclosed under FOIP (Freedom of Information and Protection of Privacy) legislation if a request for disclosure were made. It is recognized that cooperative tree improvement programs with government and any other party's information submissions to government are subject to FOIP legislation, and that other parties may request access to information through FOIP requests. The Department will refuse to release information from cooperative programs that meet all conditions as per section 16 of the FOIP Act.

In summary, disclosure would be refused where information:

a) would reveal trade secrets or scientific/technical information of a third party, and

b) would harm the competitive position of a third party or result in undue financial loss or gain to any person or organization, and

c) is supplied in confidence to the Department. 


\section{MATERIAL COLLECTION, HANDLING, REGISTRATION AND STORAGE (MCHRS)}

\section{Goals}

Genetic materials of forest trees intended for operational deployment on public land will be collected, handled, registered and stored in a way that is designed to:

- ensure adaptation and diversity,

- maintain documented genetic identity and ensure materials are appropriately tracked, and

- ensure that the genetic integrity and physical quality of materials are maintained.

\section{MCHRS Standards}

\subsection{Registration}

10.1 All material to be deployed on public land, with exceptions as noted in Standard 19, must be registered with the Department. See Appendix 2 (Stream 1) and Appendix 3 (Stream 2).

10.2 Requests for registration are subject to review and acceptance by the Department. If one or more of the following standards are not met, material may not be registered.

10.3 Required registration information must be complete, accompanied by the signature of the owner or registrant and submitted to the Department (Provincial Seed Officer). All collection, handling, storage and processing information is to be made available for Departmental review upon request.

10.4 Material that does not meet requirements for unrestricted registration may be eligible for restricted registration or for holding, pending registration eligibility (e.g. insufficient number of parents). See Appendices 2, 3, 4, and 5 for registration requirements.

10.4.1 A Stream 2 seed or vegetative lot with $N e$ insufficient for unrestricted registration may be blended with a Stream 1 seed or vegetative lot of the same species to produce a new Stream 2 lot with unrestricted registration under the following conditions:

- The Stream 1 lot has unrestricted registration;

- The Stream 2 lot has an Ne of at least 5;

- The seed zone of the Stream 1 lot and breeding region of the Stream 2 lot overlap; and

- No gain is requested for deployment of the blended lot

The blended lot shall be deployed within the area of overlap of the seed zone of the Stream 1 lot and the breeding region of the Stream 2 lot. The maximum proportion of the Stream 2 lot allowed in the blended lot is defined in the table below.

\begin{tabular}{|l|l|}
\hline Ne of Stream 2 lot & Maximum proportion of Stream 2 lot in mix \\
\hline $5-10$ & $25 \%{ }^{*}$ germination of rate of Stream 1 lot \\
\hline$>10-18$ & $50 \%{ }^{*}$ germination of rate of Stream 1 lot \\
\hline
\end{tabular}

10.5 Upon registration, the Department will assign the registered lot number. 


\section{Stream 1 material}

10.6 For registration of Stream 1 material the material collection criteria defined in Appendix 4 must be met.

10.7 For registration of Stream 1 material the following basic information is required and is to be recorded on the registration form (Appendix 2): owner, species, type of material, source location, horizontal extent of collection, the elevations of the highest and lowest collection point, seed zone, collection dates, number of parents, ARIS code (Appendix 6), amount being registered, storage location and signature of registrant.

10.7.1 For registration of Stream 1 seed, the following additional information is required: temporary lot number, volume of cones collected (conifer), yield, viability or germination $\%$, purity, moisture content and 1000 seed weight.

10.7.2 For registration of Stream 1 vegetative material, no additional information is required.

10.8 Material meeting unrestricted registration requirements of the table in Appendix 4 is eligible for deployment up to $1 \mathrm{~km}$ outside the seed zone of origin (see Appendix 7) provided the difference in elevation between point of collection and point of deployment does not exceed $100 \mathrm{~m}$. Such material is also eligible for transfer across a seed zone boundary according to Standard 18.2.5.

\section{Stream 2 material}

10.9 For registration of Stream 2 material (see Appendix 3), the effective population size criteria contained in Appendix 5 must be met.

10.10 Stream 2 material must originate from a Department-approved facility (see Standards 32.2 and 32.7).

10.11 For registration of Stream 2 material, the following is required: temporary lot number, owner, species, type of material, production facility, collection dates, amount being registered, storage location, list of parents represented, crop genetic worth (where available), deployment zone, effective population size, ARIS code (Appendix 6) and signature of registrant.

10.11.1 For registration of Stream 2 seed, the following additional information is required: volume of cones collected (conifer), yield, viability or germination \%, purity, moisture content and 1000 seed weight.

10.11.2 For registration of Stream 2 vegetative material, the contribution (\%) of each clone to the vegetative lot is required.

\section{Restricted registration}

10.12 Restricted registration (see Appendices 2 and 3) may apply where:

- documentation standards of 10.7 above have not been met, OR

- collections (Stream 1) do not meet requirements for unrestricted registration (see Appendix 4), OR

- documentation standards of 10.11 above have not been met, OR

- effective population size (Stream 2) is less than that required for unrestricted registration (see Appendix 5), OR

- Stream 2 material is derived from non-local sources (e.g. non-local provenances, nonlocal species, non-local hybrids, genetically modified organisms as determined on a caseby-case basis).

10.13 Conditions on deployment may be applied on restricted registration material. See Standard 18.2.6 and Appendix 8 (Stream 1); Standard 18.4 and Appendix 9 (Stream 2). 


\subsection{Collection}

\subsection{Collections from public land}

11.1.1 All collections of seed and vegetative material intended for reforestation or for research supporting reforestation that is carried out on public land require an authorization from the Department as per Timber Management Regulation 141.5.

11.1.2 Forest tenure holders responsible for reforestation will outline their intent to collect in their Annual Silviculture Schedule. The Department is to be notified of the target species and location of a collection prior to 48 hours of a collection taking place.

11.1.3 Collections of forest tree material by other than forest tenure holders require a temporary field authorization (TFA) from the Department field office (Appendix 10). The proponent(s) will submit a map and collection plan identifying the area of collection, type of material, method of harvest, timing and target species.

11.1.4 Authorization for native plant material collections not intended for reforestation requires a TFA and must follow the Native Plant Revegetation Guidelines for Alberta (see the Alberta Agriculture website).

11.1.5 For collections falling within legislated protected areas, permits will be required from Parks and Protected Areas, Alberta Community Development.

11.1.6 Genetic material collected from public land for research or controlled parentage programs (CPP) will be documented on the appropriate form (Appendix 11 or 12) and submitted to the Department (in either hard copy or electronic format) within six months of collection completion.

11.2 Each disposition holder will maintain a minimum of one registered Stream 1 lot for each species, in each seed zone where artificial regeneration is planned using seedlings. In the event that no seed is available, a variance request may be considered (refer to Appendix 13 and Appendix 18).

11.3 The maximum registered seedlot or vegetative lot size will depend on numerical restrictions on deployment from a single seedlot or vegetative lot. Maximum numbers deployable by seed zone size are as shown in Appendix 14.

11.4 Stream 1 vegetative material may be multiplied in stoolbeds established from collections that contain the required minimum number of trees per collection for Stream 1 material (see Appendix 4 - Material Category D).

11.5 Genetic material collected from sources other than public land (non-local) will be documented on the appropriate form (Appendix 15) and submitted (in either hard copy or electronic format) to the Department upon entry into an approved controlled parentage program or prior to deployment in research tests on public land.

11.6 Collections from approved production facilities

11.6.1 Collections from Department-approved production facilities do not require an authorization (see PCPM Standards for collection standards and guidelines).

\subsection{Transportation of Material}

12.1 A proper identification tag must accompany each container of material/cones from the time of collection to delivery to the processing and/or storage facility.

- Identification for Stream 1 material must include the temporary lot number; the material's owner; Section, Township, Range and Meridian; year of collection and species. 
- Identification for Stream 2 material must include the temporary lot number, the material's owner, orchard number, year of collection and species.

12.2 When research or CPP parent material is collected, shipped or stored, it must be accompanied by the Transportation and Storage Label Form (Appendix 16) and either the accession number, registered lot number or unique identifier.

\subsection{Transportation of materials from public land}

12.3.1 A completed Registration Request Form - Stream 1 (Appendix 2) must accompany all shipments of public land collections of seed and vegetative material intended for reforestation.

\subsection{Transportation of materials from an approved production facility}

12.4.1 A completed Registration Request Form - Stream 2 (Appendix 3) must accompany all cone and material shipments.

\subsection{Withdrawal and transportation}

12.5.1 A completed Reforestation Seed and Vegetative Materials Withdrawal and Transportation Form (Appendix 17) must be received by the Department (Provincial Seed Officer) before a seed or vegetative material withdrawal may be made.

12.5.2 Unless approved by the Department (Provincial Seed Officer), withdrawals of seed or vegetative material for deployment are not permitted until registration is complete.

12.5.3 A Reforestation Seed and Vegetative Materials Withdrawal and Transportation Form (Appendix 17) is to be used for tracking materials from withdrawal from storage through to nurseries or related facilities. The Department (Provincial Seed Officer) is to be notified of any deviation from the original documentation.

\subsection{Processing}

13.1 Processing of seed for operational deployment must be carried out at a seed processing facility approved by the Department. In order to be approved, seed processing facilities must have the verifiable capability to maintain accurate identity and seedlot integrity. For a list of approved seed processing facilities, see the Department's website.

13.2 Seeds and vegetative materials must have verifiable identity documentation, and the integrity of individual lots must have been maintained throughout the process. Any mixing of collections must be done and documented in such a way that the eventual distribution of individuals can be assured to be random within the deployment lot.

13.3 Seed shall be processed and delivered for storage within six months of collection.

13.4 The completed Registration Request Form (Appendix 2 or Appendix 3) must accompany the seed to the Alberta Tree Improvement and Seed Centre (ATISC) or other recognized storage facility for registration.

13.5 Where seed and vegetative material lots are split for any reason, the Registration Request Form (Appendix 2 or Appendix 3) must be included with each portion.

13.6 Seed processing facilities are not permitted to withhold any reforestation seed or ship reforestation seed to any location except ATISC or another approved storage facility without the written permission from the seed owner and the Department (Provincial Seed Officer).

\subsection{Seed Testing}

14.1 Seed testing must be conducted in accordance with the Department's Seed Testing Guidelines, which are published on the Department's website or supplied by ATISC.

14.2 An experienced seed testing technician or laboratory scientist responsible for the seed testing laboratory must sign seed test result reports. 
15.0 Storage

15.1 All registered seed must be stored at ATISC or another storage facility approved by the Department.

15.2 Registered vegetative materials that need to be maintained in growing conditions for propagule production must be stored or maintained at an approved storage facility. An approved production facility undertaking propagule production for deployment on public land is considered an approved storage facility.

15.3 The Department will review requests for approval of storage facilities other than ATISC on the basis of physical infrastructure and management processes.

15.4 Seed and vegetative material received for storage must be securely packaged and labeled with the temporary or registered lot number as written on the accompanying Registration Request Form - Stream 1 (Appendix 2). Containers must have one tag inside and one tag securely affixed to the outside.

15.5 All seed and vegetative materials storage facilities must follow handling and storage procedures that maintain lot identity and integrity.

15.6 For storage of unregistered collections not originating on public land, or of seed and vegetative materials obtained from other agencies, the minimum information required is: species, seed source, moisture content, 1000 seed weight and total seed amount submitted for storage at ATISC or other approved storage facility.

\subsection{Excess Seed, Seedlings and Vegetative Material}

16.1 Nurseries and/or propagation facilities are not permitted to sell or distribute excess seed, seedlings or vegetative material for deployment on public land without prior approval of the material owner and the Department (Provincial Seed Officer). Exchanges of material between material owners does not require Department approval as long as the standards within this manual are followed with deployment of the material.

\subsection{Retention of Material for Ex Situ Conservation}

17.1 The Department has the right to retain samples of tree seed and vegetative material collected from public land for the purpose of conservation of wild seed or vegetative genetic resources.

17.1.1 For Stream 1 seedlots, the Department may, at the time of registration, access up to 30,000 viable seeds or $5 \%$ of the initial total seedlot, whichever is less. The Department will notify the owner of any withdrawals. Amounts greater than this will require written consent of the company.

17.1.2 The Department may access Stream 2 material with written consent from the company.

17.1.3 For seed collections from public land intended for inclusion in research or controlled parentage programs in Alberta, the Department may request that $5 \%$ of the seed be provided to the Department.

17.1.4 For all other public land seed or vegetative material collections not intended for reforestation or tree improvement in Alberta, the Department may request that $10 \%$ of harvested seed or vegetative material be provided to the Department. 


\section{GREEN AREA DEPLOYMENT (GAD)}

Goals

Genetic resources of forest trees will be deployed within the Green Area in a way that strives to:

- conserve the genetic integrity, adaptability, diversity and health of wild and managed populations while recognizing that genetic change will occur through evolutionary pressure, breeding and deployment,

- maintain or enhance forest productivity,

- be consistent with sustainable forest management principles (economic, social and environmental sustainability), and

- recognize that the Detailed Forest Management Plan (DFMP) or plans of an equivalent level, guided by this and other related policies, will determine how deployment will occur.

\section{GAD Standards}

\subsection{Deployment of Registered Material}

\subsection{General}

18.1.1 Only registered materials - unrestricted or restricted - may be deployed within the Green Area (see exceptions in Standard 19.0).

\subsection{Deployment of Stream 1 materials}

18.2.1 Stream 1 materials are collected for deployment within the seed zone of origin. Seed zones are those delineated on the Seed Zone Map provided in Appendix 7.

18.2.2 For seed and vegetative material collections made before May 1, 2003, the need for a variance approval to move seed outside the seed zone of origin will be determined from the decision tree in Appendix 13.

18.2.3 To maintain population diversity within a seed zone, total seedling and/or vegetative material deployment from Stream 1 sources with unrestricted registration will be limited on the basis of seed zone size as set out in Appendix 14.

18.2.4 Unrestricted material collected as set out in the table in Appendix 4 is eligible for application for deployment outside the seed zone of origin (see Appendices 8 and 13 for procedures). Unrestricted material meeting the requirements of the table may, without applying for a variance, be deployed within $1 \mathrm{~km}$ of the seed zone boundary, provided elevation from the point of collection (mid-point of range) to the point of deployment does not exceed $100 \mathrm{~m}$. See Appendix 14 for additional deployment considerations.

18.2.5 Movement of seed or vegetative propagules outside the seed zone of origin requires variance approval.

- Variances for Stream 1 material may be requested by submitting a Request for Deployment Variance for Stream 1 Material (Appendix 8) to the Department (Provincial Seed Officer).

- Where the same variance to deploy seed outside the seed zone of origin may be requested several times, a standing approval may be issued for a five-year period.

- Any three requests for the same variance, or any standing approval, will trigger a request for the Department (Provincial Seed Officer) to review the seed zone boundaries and seed or vegetative material collection practices.

18.2.6 For deployment of restricted Stream 1 material, a determination is to be made by the Department on the basis of a request for variance (Appendix 8). 
18.3.1 Requests for review and amendment of seed zone boundaries will be reviewed by the Director of the Forest Management Branch. Reviews will be based on ecological and genetic information.

18.3.2 Development of species-specific seed zones will require testing according to Standard 28.4.

\subsection{Deployment of Stream 2 materials}

18.4.1 Deployment of Stream 2 material as clonal blocks or rows is addressed through assessment as per Appendices 1 and 9.

18.4.2 Total seedling and/or vegetative material deployment from Stream 2 sources from a given production facility or facilities will be limited by breeding region or deployment zone as defined in the Controlled Parentage Program (CPP) Plan (see Appendix 18). For a list of existing breeding regions, see Appendix 19.

18.4.3 Deployment of Stream 2 Materials and Cumulative Effective Population Size

a) Seed: total deployment of Stream 2 seed for a given deployment zone will be limited by the cumulative effective population size $(\mathrm{Ne})$ of the output from associated orchard(s). The total deployment from the associated orchard or orchards, where estimated cumulative Ne summed over the life of the orchard(s) is less than 30, may not exceed $25 \%$ of the total area estimated for the target strata over a rotation. An orchard or orchards with estimated cumulative $\mathrm{Ne}$ of 30 or more may produce material for deployment on up to $50 \%$ of the total area estimated for target strata over a rotation (Appendix 21 provides the method for calculating these cumulative $\mathrm{Ne}$ deployment levels). For deployment on areas greater than $50 \%$ of the total area estimated for the target strata, over a rotation, an acceptable cumulative $\mathrm{Ne}$ for output from the orchard(s), must be approved by the Department.

b) Vegetative Materials: total deployment of Stream 2 vegetative materials for a given deployment zone will be limited by the cumulative effective population size of the output from the associated production facility or facilities. The total deployment from a production facility or facilities, where estimated cumulative $\mathrm{Ne}$ (summed over the life of the facility or facilities) is less than 30 , may not exceed $20 \%$ of the total area estimated for target strata over a rotation. A facility or facilities with estimated cumulative $\mathrm{Ne}$ of 30 or more may produce material for deployment on up to $40 \%$ of the total area estimated for the target strata over a rotation (Appendix 21 provides the method for calculating cumulative $\mathrm{Ne}$ for these deployment levels). For deployment on areas greater than $40 \%$ of the total area estimated for the target strata, over a rotation, an acceptable cumulative $\mathrm{Ne}$ for output from the production facility(s) must be approved by the Department.

Note: This standard does not imply an area cap for Stream 2 material deployment to strata, but does require ensuring that output from orchard(s) and production facility(s) maintains an acceptable landscape level $\mathrm{Ne}$ for proposed deployment greater than $50 \%$ of the stratum area for seed, and $40 \%$ of the stratum area for vegetative material.

18.4.4 Deployment numbers by proponent are presented in the Detailed Forest Management Plan or Annual Operating Plans and identified in the current CPP Plan. Appendix 20 provides details of methods for calculating cumulative Ne. Appendix 21 provides the method for calculating allowed deployment levels based on cumulative $\mathrm{Ne}$, and an example of the information and format for production facility planning and reporting under a CPP Plan. 
18.4.5 Existing breeding region and deployment zone boundaries may be periodically reviewed and revised (see Standard 28.0).

18.4.6 Minor changes to existing breeding region boundaries may be made with the mutual consent of the proponent(s) and the Department.

18.4.7 Prior to deployment of restricted Stream 2 material, the Detailed Forest Management Plan (DFMP) is to contain a summary of the research tests and analysis undertaken, monitoring required, and methods of ameliorating the risks identified in Appendix 9.

18.4.8 A request for movement of seed or vegetative propagules outside the breeding region/deployment zone of origin will only be considered in emergencies, and is initiated by submitting a Request for Deployment Variance for Stream 2 Material (Appendix 22) to the Department (Provincial Seed Officer).

\subsection{Deployment of Unregistered Material}

19.1 Wild transplants and cuttings from within $5 \mathrm{~km}$ and $100 \mathrm{~m}$ elevation of the target planting site may be deployed without registration. These transplants and cuttings may not be multiplied or serially propagated.

19.2 For a single clone, a maximum of 5000 propagules may be deployed within the seed zone of collection.

\subsection{In Situ Gene Conservation}

20.1 In situ conservation for Stream 1 material or other species not identified in controlled parentage programs for a specific seed zone will be accommodated through a provincial gene conservation plan as developed.

20.2 Between two and four areas of wild forest populations (as represented by species and stratum class, e.g. timber productivity rating, timber type) are required to be designated for gene conservation for each tree species included in a CPP Plan, in each seed zone for which at least $15 \%$ of its gross area lies within the Breeding Region for that CPP Plan. A single area may provide conservation for more than one species. The number of gene conservation areas required will depend on the area of seed zone contained within the breeding region as follows:

\begin{tabular}{|c|c|}
\hline $\begin{array}{c}\text { Area of Seed Zone Size Within } \\
\text { Breeding Region }\end{array}$ & Number of Conservation Areas Required \\
\hline$>1.0$ million ha & 4 per species \\
\hline $0.5-1.0$ million ha & 3 per species \\
\hline$<0.5$ million ha & 2 per species \\
\hline
\end{tabular}

Where less than $15 \%$ of a seed zone lies within the specified Breeding Region, gene conservation areas are not required.

For sizes of specific seed zones, see Appendix 7.

These gene conservation areas may be chosen from:

20.3 existing reserves, OR

20.4 subjective landbase deletions (e.g. streamside buffers, non-merchantable, inoperable), OR

20.5 harvestable areas dedicated for natural regeneration (e.g. natural seeding or partial cutting), or for planting with seed specifically from the site, or with wild Stream 1 collections from adjoining areas, OR 
20.6 understory protection and variable retention areas (retain some naturals, supplement with planting with seed specifically from the core area [see Appendix 4] or if not available, wild Stream 1 collections from adjoining areas).

20.7 In situ gene conservation areas will be implemented as follows:

20.7.1 Areas designated for gene conservation will be dispersed across the seed zone to minimize risk of loss.

20.7.2 Areas designated for gene conservation will be chosen with consideration for long-term protection from biological and non-biological threats. A CNT (Consultative Notation) is recommended for these areas.

20.7.3 Areas will be large enough to meet a reasonable expectation of 5000 trees (at rotation) in a core area with an additional buffer of $500 \mathrm{~m}$ around it.

20.7.4 The target species as identified in the CPP Plan will be managed as per the options specified in Standards 20.2 and 21.1.3.

20.8 For a given species, in any seed zone where Stream 2 material is being planted, the CPP plan(s) will indicate how in situ standards are being met. Because breeding regions/deployment zones may include more than one seed zone and more than one cooperator, cooperative planning among parties in each breeding region/deployment zone may be required.

\subsection{Deployment Planning and Reporting}

21.1 Planning for Stream 2 Deployment

21.1.1 Annual deployment schedules, as shown in the Annual Silviculture Schedule of an Annual Operating Plan (AOP), will be consistent with the approved DFMP deployment strategies.

21.1.2 In the absence of approved DFMP deployment strategies, annual deployment schedules will be approved when consistent with production objectives as defined in the approved CPP Plan (see Standard 24.0).

21.1.3 Areas designated for gene conservation will be described in the DFMP, which will also include a statement of intended management on a time horizon of two rotations.

\subsection{Reporting}

21.2.1 Compliance monitoring of deployment activities (Streams 1 and 2) will be reported in the Five Year Stewardship Report of the Detailed Forest Management Plan. Performance measures will be DFMP-specific and designed to assure plan assumptions are adequately monitored. At a minimum, cumulative deployment of each source/type of material will be reported.

21.2.2 Deployment of all registered material will be reported annually to the Department in the Alberta Regeneration Information System (ARIS).

21.2.3 A map showing deployment by cutblock for the past five years' activities, of appropriate scale, will be submitted, when:

21.2.3.1. restricted registration Stream 2 material lots are planted, $O R$

21.2.3.2. unrestricted registration Stream 2 material from a given production facility exceeds an average of $50 \%$ of areas reforested by stratum and species in a five-year period. 
This will be reported in conjunction with the Five Year Stewardship Report of the DFMP. Digital files will be accepted in lieu of hard copy format.

21.2.4 Compliance with in situ gene conservation standards will be indicated by specifying, in the Five Year Stewardship Report, the status of designated areas.

\subsection{Post-Deployment Monitoring}

22.1 Growth and yield monitoring will be as per the DFMP and FMA requirements.

22.2 Monitoring requirements for restricted registration material will be determined through the Assessment of Risk for Stream 2 Material (Appendix 9). This is a case-by-case assessment.

\subsection{Genetic Research Plantings}

23.1 Research plantings can be established covering an area of up to 17 ha per site. Variances for contiguous research plantings larger than 17 ha may be requested by submitting a Request for Planting Variance for Research Material (Appendix 23) to the Department (Provincial Seed Officer).

23.2 All materials included in research plantings must have a material identity (unique identifier, accession number or registered lot number).

23.3 All research plantings must meet BTV Standards.

23.4 Research plantings that include material of uncertain or unknown adaptation (non-local) require approval through a Research Program Plan or Controlled Parentage Program (CPP) Plan.

23.5 Research plantings including genetically modified organisms (GMOs) must comply with both federal regulations and provincial policy.

23.6 A standing approval can be requested for planting material from subsequent collections from the same source.

23.7 Where a previously untested, non-local species or provenance (including hybrids) is to be planted in a research test that exceeds 17 ha, a benefit/risk assessment as per Appendix 23 will be required with the variance request.

23.8 Out-of-zone/breeding region material may require additional monitoring. 


\section{BREEDING, TESTING AND VERIFICATION (BTV)}

\section{Goals}

Forest genetics programs that produce Stream 2 material or information relating to Stream 2 material for deployment on public land in the Green Area shall:

- use testing, analysis and documentation protocols that are effective, efficient and scientifically sound, and

- be designed to ensure long-term flexibility in direction and development of controlled parentage programs, and

- produce reliable estimates of genetic gain when gain is included as an objective of the Controlled Parentage Program (CPP) Plan.

\section{BTV Standards}

\subsection{Controlled Parentage Programs (CPPs)}

24.1 Proponent(s) of CPPs that existed prior to the effective date of these standards and are intended to produce material for deployment on public land will submit a CPP Plan in electronic or hard copy (see Appendix 18). The date for submission will be determined by consultation between the proponent(s) and the Department.

24.2 New CPPs require an approved CPP Plan. Proponent(s) of new CPPs that are intended to produce material for deployment on public land will submit a CPP Plan in electronic or hard copy (see Appendix 18). The CPP Plan approval process is initiated when the proponent sends a letter of intent to the Department. The Department will respond within three months of receiving the letter of intent. Provided the proponent submits its plan within 18 months of the letter of intent, resolution can be expected within 24 months after the letter of intent is received.

24.3 Where a new or revised CPP Plan is not approved by the Department, the proponent(s) may request that the Director, Forest Management Branch, appoint a third party to review the technical merit of the plan. The Department will consider the third party's advice and provide a decision.

24.4 CPP plans intended to produce Stream 2 material will identify:

- the total area (ha) by participating tenure holder within the target breeding region/deployment zone,

- the total operable area (ha) by tenure holder within the breeding region/deployment zone,

- the target strata (species by breeding region, not yield stratum) for which the Stream 2 production facility is designed,

- the total area (ha) of target strata by tenure holder,

- estimated plants required for $100 \%$ planting of target strata area per rotation for each participating tenure holder,

- estimated annual number of seedlings and/or vegetative propagules from a production facility allocated to each participating tenure holder, and

- planned total production of seedlings and/or vegetative propagules over the life of the facility.

24.4.1 To determine deployment limits for a production facility or facilities and for an example of information and presentation format for CPP planning, refer to Appendix 21 and Standards 18.4.1 through 18.4.4.

- For Stream 2 restricted registration material, see also Standards 18.4 .7 and Appendix 9. 


\subsection{Revisions to Controlled Parentage Program Plans}

24.5.1 When significant changes occur, revised CPP Plans will be submitted to the Department for review. The Department will respond within three months of submission.

\subsection{Research Programs}

25.1 All genetic testing intended to provide information relating to deployment on public land, and not currently covered in a CPP Plan, will require a Research Program (RP) Plan to be submitted for approval by the Department (see Appendix 1 and Appendix 24).

25.2 All genetic research field tests on public land will comply with GAD Standards and field test standards where appropriate.

25.3 Upon a request to deploy non-local material (or with prior federal approval, PNTs or GMOs) on Green Area public land, the Department:

- will review all relevant scientific information on a case-by-case basis to evaluate the risks and benefits of deployment, and

- may request an RP Plan and additional testing prior to considering inclusion of such material in a CPP.

25.4 Genetic research tests intended to produce information relating to deployment on public land in the Green Area will follow applicable standards in Standards 23.0 and 30.0.

25.5 All unregistered material destined for testing on public land or for inclusion in breeding/base population to be deployed on public land will be labelled using unique identifiers. (See Appendix 25 for codes and Appendices 11, 12, or 15 for the appropriate submission form.).

25.6 Consultation with the Department is advised if a proponent is intending to establish a realized gain trial. The Department can provide clarification regarding an acceptable design and methodology to provide information on stratum level genetic gain.

25.7 Where a new or revised RP Plan is not approved by the Department, the proponent(s) may request in writing that the Director of the Forest Management Branch appoint a third party to review the technical merit of the plan. The Department will consider the third party's advice and provide a decision.

\subsection{Genotype Information and Pedigree Records}

26.1 Agencies and companies involved in controlled parentage and research programs with the intent of developing genetic material for deployment on public land will maintain and submit to the Department:

- complete records of parentage and/or pedigree for genotypes collected from public land (see Appendices 11 and 12),

- $\quad$ parentage and/or pedigree for genotypes established in production facilities (see Appendix 15 and Standards 33.5 and 34.4), and

- associated genotype information related to species, origin, traits identified in program plans and issues of adaptation or claims for gain (as per genetic test analysis reports or requirements arising out of $\mathrm{CPP}$ and $\mathrm{RP}$ Plans).

\subsection{Field Test Data Handling, Storage and Access}

27.1 For genetic tests established as part of a CPP or RP Plan, an electronic listing will be prepared, in ASCII or another previously agreed-upon format that will allow the unambiguous identification of each test tree in the field when accompanied by the appropriate $\operatorname{map}(\mathrm{s})$. This listing will contain:

- Department-assigned project number and site identifier (e.g. G625C),

- test site name, 
- replication/block,

- experimental tree position/location, and

- genetic identity (accession number, registered lot number or unique identifier).

27.2 This file will be submitted to the Department as part of the Genetic Test Establishment Report (see Standard 30.12.1 and Appendix 26).

27.3 Each successive measurement of a genetic test is to use the same listing to allow compiling of time series data sets.

27.4 Validated raw data will be submitted to the Department as electronic files using the listing defined in Standard 27.1 to identify individual trees.

27.5 Validated raw data will be accompanied by a data dictionary describing measurement methods and procedures, variables, format, measurement units and measurement codes, quality control procedures and results, assessors, assessment dates and any field assessment comments. Submission of data must follow the reporting standards outlined in Standard 30.0 and Appendix 27.

27.6 Any data or tree code discrepancies identified by the Department in validated raw data sets will be reviewed and corrected by the measuring agency (i.e. company, contractor, scientific cooperator).

27.7 For each genetic research test, validated raw data files will be compiled by the Department as new data are submitted and archived in a secure system with backup.

27.8 The Department requires submission of any edited data sets used to support claims of adaptation, diversity or performance of tests established under CPP or RP Plans.

27.9 The Department will provide cooperators with validated raw test data in ASCII format, along with required supporting documentation, contingent on the cooperator's right to such material and knowledge.

\subsection{Delineation and Revision of Breeding Regions, Deployment Zones and Species- Specific Seed Zones}

28.1 Processes used to delineate new breeding regions or deployment zones (e.g. provenance/progeny tests) will be included in the associated CPP Plan or supporting RP Plan.

28.2 Revision of existing deployment zones (including breeding regions) may be conducted under an RP Plan or revision to an existing CPP Plan.

28.3 A request submitted to the Department for the establishment of a new deployment zone (breeding region) or the revision of an existing deployment zone (breeding region) must include all supporting documentation. The Department will respond within three months of submission.

28.4 Establishment of species-specific seed zones will require an RP Plan and genetic provenance testing for adaptation.

\subsection{Ex Situ Conservation of Native Species}

\subsection{General}

The Department will be notified of plans to terminate any genetic test, clone bank or orchard of native Alberta material on public or private land prior to termination of genetic material.

Documentation on genetic material identity will be made available to the Department.

\subsection{Samples of genetic tests - public land}

29.2.1 When genetic tests on public land have fulfilled their purpose, the Department may choose and maintain a sample of tests for gene conservation purposes. 
29.3 Samples of genetic tests - private land

29.3.1 When genetic tests of native species collected from public land are conducted on private land, the Department will have the opportunity to negotiate for maintenance of a sample of tests or to collect genetic material before it is destroyed. A material transfer agreement may be required or a lease agreement considered.

\subsection{Clone banks or orchards}

29.4.1 The Department will have the opportunity to obtain vegetative material from each native parent selected from public land that is being vegetatively propagated. Reciprocal access is provided, and a material transfer agreement may be required.

29.4.2 Prior to clone destruction (e.g. through roguing), each party will provide notification and access to the clonal material.

\subsection{Reporting and documentation}

29.5.1 Documentation for gene conservation in clone banks and samples of genetic tests will include a map for access to the site, a list of included genetic materials and their origins, a map showing tree location/position and the name, e-mail address and phone number of the contact company(ies) and person(s), as well as, where it exists, a copy of the material transfer agreement.

\subsection{Genetic Research Tests}

30.1 Analyses of genetic tests conducted under a CPP or RP Plan will be reported as outlined in Appendix 28.

30.1.1 Where a genetic analysis report is to be submitted in support of a claim for gain, the proponent will submit a letter of intent to the Department specifying which of the following options will be followed:

a. Follow procedures outlined in the example report "Genetic Analysis Report for Region E White Spruce Tree Improvement" (example report is posted on the web at http://www3.gov.ab.ca/srd/forests/fmd/manuals/index.html);

b. Submit a proposal for alternate procedures prior to analysis to the Department.

\subsection{Number of test sites}

30.2.1 For progeny tests associated with a CPP Plan, data from no fewer than three test sites, or the number specified in the CPP or RP Plan, will be used for analyses.

30.2.2 For establishment of new deployment zone boundaries for non-local material, data from a minimum of five provenance test sites will be used. The number of test sites may vary depending on the size of the proposed deployment zone and will be specified in the CPP or RP Plan.

30.2.3 For revision of breeding, deployment or seed zone boundaries, the number of test sites will be specified in the CPP or RP Plan.

30.2.4 For establishment of species-specific seed zones, the number of test sites will be specified in the RP Plan.

\subsection{Site selection and documentation}

30.3.1 Sites will be well distributed geographically and elevationally across, and representative of, the actual or proposed breeding, deployment or seed zone.

30.3.2 For acceptance and approval of a trial series, a Genetic Test Site Information Form (Appendix 29) must be submitted for each test site and approved by the Department. 


\subsection{Site protection}

30.4.1 A protective notation/reservation or appropriate public land disposition will be obtained prior to test establishment (ISP or MLL).

\subsection{Field marking}

30.5.1 Field marking will be established and maintained that allows for identification of each test tree, complete with an establishment report map(s) and description of all coding systems used. See Appendix 30, "Example of Data Collection Map and Corresponding Form."

30.5.2 The starting point for assessments will be clearly and permanently marked in the field and on establishment report map(s).

30.5.3 At least $5 \%$ of test trees, or the number or proportion specified in the CPP or RP Plan, will have a permanent marker stake.

\subsection{Site maintenance - competition and ingress control}

30.6.1 Competing vegetation and ingress of the target species will be managed in a manner specified in the CPP or RP Plan to allow free growth and identification of test trees.

30.6.2 Ingress of target species, if present or anticipated, will be monitored annually for the first three years and as needed thereafter.

\subsection{Site maintenance - maintenance of tree identification}

30.7.1 Field labelling will be checked in the year following establishment and the time of each scheduled measurement. Missing or illegible labels will be replaced within four months of each labelling check.

\subsection{Monitoring - data submission}

30.8.1 Quality control procedures associated with test assessments will be detailed in the Genetic Test Measurement Report (see Appendix 27).

\subsection{Monitoring - timing}

30.9.1 Growth traits on a given field test site will be measured within one dormant season.

\subsection{Monitoring - variables}

30.10.1 Survival code and other variables specified in the CPP or RP Plan will be recorded at each measurement.

30.10.2 The height of trees shorter than $3 \mathrm{~m}$ will be measured to the nearest $\mathrm{cm}$. Trees of height greater than $3 \mathrm{~m}$ will be accurate to the nearest $\mathrm{dm}$ (i.e. $0.1 \mathrm{~m}$ ). Units of measurement must be consistent for traits in the measurement period (e.g. all heights in $\mathrm{cm}$ ).

30.10.3 Height will be measured to within $5 \%$ of true values $95 \%$ of the time, based on the use of standard measurement equipment, measurement procedures and sampling precision.

30.10.4 Diameter at Breast Height (DBH) will be measured to the nearest $\mathrm{mm}$ and recorded in $\mathrm{cm}$.

30.10.5 The DBH of trees larger than $10 \mathrm{~cm}$ will be measured to within $5 \%$ of the true value $95 \%$ of the time. Smaller trees will be measured to within $5 \mathrm{~mm} 95 \%$ of the time.

\subsection{Monitoring - duration of measurements and long-term monitoring}

30.11.1 Duration of measurements will be specified in the CPP or RP Plan.

30.11.2 Long-term monitoring will be specified in the CPP or RP Plan. 


\subsection{Monitoring - reporting}

30.12.1 A Genetic Test Establishment Report (see Appendix 26) will be submitted to the Department by November 30 of the year following establishment.

30.12.2 A Genetic Test Measurement Report (see Appendix 27) will be completed and submitted together with validated raw data sets in electronic format within eight months of completion of the current year's measurements. Data sets will be cleaned and formatted.

\subsection{Termination of genetic test, clone bank or orchard}

30.13.1 See "Ex Situ Conservation," Standard 29.0.

\subsection{Genetic Gain Approval}

31.1 The process for approval of genetic gain begins with a request by a proponent to the Department, stating an average value expected for specific traits. The Department will provide a response to a request within three months of receipt.

31.2 Approval of a genetic gain value will be based on review of the CPP Plan and one or more of:

- associated RP Plans,

- results of genetic tests (e.g. genetic worth calculation - Appendix 31),

- literature review,

- expert opinion,

- results from other programs, and

- other relevant information.

31.3 Any increase to the AAC attributable to genetic gain must be approved through the DFMP process.

31.4 Currently, claims for genetic gain are based on height.

31.5 The minimum age of test evaluation in support of a claim for genetic gain based on progeny testing will be calculated as:

Minimum age in years $=4+0.1 \times$ (midpoint of rotation age class) as shown in Table 1 below.

Table 1. Minimum test evaluation age to support claims for genetic gain

\begin{tabular}{|c|c|c|}
\hline Rotation age & $\begin{array}{c}\text { Midpoint of rotation } \\
\text { age class }\end{array}$ & $\begin{array}{c}\text { Minimum evaluation } \\
\text { age }\end{array}$ \\
\hline $6-15$ & 10 & 5 \\
\hline $16-25$ & 20 & 6 \\
\hline $26-35$ & 30 & 7 \\
\hline $36-45$ & 40 & 8 \\
\hline $46-55$ & 50 & 9 \\
\hline $56-65$ & 60 & 10 \\
\hline $66-75$ & 70 & 11 \\
\hline $76-85$ & 80 & 12 \\
\hline $86-95$ & 90 & 13 \\
\hline $96-105$ & 100 & 14 \\
\hline $106-115$ & 110 & 15 \\
\hline $116-125$ & 120 & 16 \\
\hline
\end{tabular}

31.6 For non-local material, adaptation and yield may be assessed on the basis of performance at the age of 20 years or half the anticipated rotation age, whichever is earlier. 


\section{PRODUCTION OF CONTROLLED PARENTAGE MATERIALS (PCPM)}

\section{Goal}

Stream 2 seed and vegetative materials of controlled parentage for deployment on public land will be produced:

- in Department-approved production facilities using established procedures,

- in a manner that maintains the potential to produce a crop that can be registered with a calculated effective population size (diversity) and crop genetic worth, and

- in a manner that ensures that documentation and reporting provide verification of claims for registration of materials produced.

\section{PCPM Standards}

\subsection{General}

32.1 Operational production facilities and procedures must have the potential to produce registered crops of seed or vegetative materials for deployment on public land.

32.2 The Department will approve facilities for production of materials on the basis of a review of an application submitted to the Department, preferably prior to selecting a production facility location. An application will include a risk assessment that will address the following where appropriate:

- pollen contamination for proposed orchard,

- infrastructure (e.g. roads, water source, labour supply, expansion capability, facility modification),

- environment,

- potential pest risks,

- security in space and time, and

- preconditioning/adaptation (e.g. for production environments differing significantly from deployment environments).

32.3 A production facility on public land must be protected by a public land disposition or other notation.

32.4 Each production facility is designated for a single specified deployment zone to ensure adaptation.

32.5 Production of controlled parentage materials must be integrated with an approved Controlled Parentage Program (CPP) Plan. Such facilities may have multiple objectives (e.g. clone bank plus production).

32.6 The maximum amount of registered Stream 2 material, over the life of a production facility or facilities for a given deployment zone, will depend on numerical restrictions on total deployment from the production facility or facilities (see Appendices 20 and 21). The maximum number deployable will vary by breeding region or deployment zone, and will be included in the CPP Plan as per Standard 24.0.

32.7 A facility review will include inspection of each production facility to assess the ability of the owner to fulfil Department requirements.

- Owners of existing facilities will provide the Department with information supporting Department approval.

32.8 Continued compliance with approval conditions is required to maintain an approval to produce material for public land deployment. Technical audits may be used to verify compliance. 
32.8.1 Completed Production Facility Establishment Reports and addenda (or equivalent) must be submitted by February 28 as outlined in Appendix 32. A sample establishment report is available on the Department's website.

32.8.2 All orchards must follow the Permanent Sample Tree (PST) Protocols contained in Appendix 33.

32.8.3 All orchards must follow the Phenology and Pollen Monitoring Protocols contained in Appendix 34.

32.8.4 An Annual Operations Report shall be submitted by February 28 as outlined in Appendix 35.

32.9 An approval will be reviewed every five years, or sooner where significant changes to the facility have occurred.

32.10 An approval may be cancelled for failure to comply with the standards or for submitting information that is known to be incorrect or purposely misleading.

\subsection{Seed Material Production}

33.1 An orchard must be designed to produce a seed crop of a minimum effective population size of 18 .

33.2 Orchards must be designed using specialized design software (e.g. SOL32 or SOMAD).

33.3 Crop genetic worth is calculated according to the procedures outlined in Appendix 31 .

33.4 Effective population size is calculated according to procedures outlined in Appendices 36 and 37.

33.4.1 The basis for collecting required data to calculate the effective population size is through sampling of contributing parents as outlined in Appendix 37.

33.4.2 Calculations will be documented and records/data retained and provided upon request for possible auditing.

33.4.3 Where a seed orchard with cumulative Ne of less than 30 has reached its limit for total production (see Standard 18.4.3 and Appendix 21), a replacement orchard will be required. The new orchard, together with the previous orchard, must have a planned cumulative $\mathrm{Ne}$ of at least 30 . Appendix 20 provides details of methods for calculating cumulative Ne.

33.4.4 Material deployed from a rolling front orchard must have a cumulative $\mathrm{Ne}$ of at least 30 by the time $50 \%$ of the target strata area has been regenerated with that material (see Appendix 21). Appendix 20 provides details of methods for calculating cumulative $\mathrm{Ne}$.

33.5 The genetic identity, and where available the pedigree, of seed orchard parents must be maintained. 
33.6 Documentation for each crop submitted for registration must include:

- owner,

- species,

- type of material,

- production facility,

- collection dates,

- temporary lot number,

- amount being registered,

- storage location,

- crop genetic worth (Appendix 31),

- deployment zone (Appendix 19),

- effective population size (Appendix 36),

- ARIS code (Appendix 6),

- signature of registrant, and

- seedlot composition (proportion of the seedlot contributed by clone/family).

\subsection{Vegetative Materials Production}

34.1 Crop genetic worth is calculated according to procedures in Appendix 31 .

34.2 A vegetative lot must be assembled from production facilities to produce a crop minimum effective population size of 18 for unrestricted registration.

34.3 Effective population size is calculated according to procedures in Appendix 36.

34.3.1 The individual clonal contribution to a crop must be known in order to meet data requirements for calculating effective population size for Stream 2 vegetative materials in Appendix 36.

34.3.2 Calculations will be documented and records/data retained and provided upon request for possible auditing.

34.3.3 Where a production facility or facilities for vegetative material with cumulative Ne of less than 30 has reached its limit for total production (see Standard 18.4.4 and Appendix 21), a replacement facility will be required. The new facility, together with the previous facility, must have a planned cumulative $\mathrm{Ne}$ of at least 30 . Appendix 20 provides details of methods for calculating cumulative Ne.

34.4 The genetic identity, and where available the pedigree, of clones in the production facility must be maintained.

34.5 Documentation of each crop submitted for registration must include:

- owner,

- species,

- type of material,

- production facility,

- collection dates,

- temporary lot number,

- amount being registered,

- storage location,

- crop genetic worth (Appendix 31),

- deployment zone (Appendix 19),

- effective population size (Appendix 36),

- $\quad$ ARIS code (Appendix 6),

- signature of registrant, and

- genetic composition (proportion of the vegetative lot contributed by clone/family). 


\begin{tabular}{|c|c|}
\hline Term & Definition \\
\hline $\begin{array}{r}\text { Accession } \\
\text { number }\end{array}$ & $\begin{array}{l}\text { Four-digit number historically assigned by the Department to research seedlots. } \\
\text { These may include individual family collections or bulked seedlots. Accession } \\
\text { number is one category of genetic identity. }\end{array}$ \\
\hline $\begin{array}{l}\text { Adapted } \\
\text { material }\end{array}$ & $\begin{array}{l}\text { Material resulting from natural evolution, or breeding and testing, that is capable of } \\
\text { adequate growth and reproduction in a given habitat and that will not have adverse } \\
\text { impacts on the health, functioning and productivity of the ecosystem. }\end{array}$ \\
\hline Afforestation & $\begin{array}{l}\text { The establishment of a tree crop on an area from which the crop has always been } \\
\text { absent, or absent for a very long time. }\end{array}$ \\
\hline $\begin{array}{l}\text { Amplified } \\
\text { family }\end{array}$ & $\begin{array}{l}\text { An aggregate of multiple vegetative propagules from each of several to many } \\
\text { members of a half- or full-sib family. }\end{array}$ \\
\hline $\begin{array}{l}\text { Approved } \\
\text { facility }\end{array}$ & $\begin{array}{l}\text { A designation provided to a facility that is qualified to produce material for } \\
\text { deployment. }\end{array}$ \\
\hline Base population & $\begin{array}{l}\text { The population of trees from which individuals are chosen to establish the breeding } \\
\text { population and/or production population for a controlled parentage program. } \\
\text { Generally refers to a wild population within a breeding region; may include trees } \\
\text { from adjacent or other regions. }\end{array}$ \\
\hline $\begin{array}{l}\text { Breeding } \\
\text { population }\end{array}$ & $\begin{array}{l}\text { A set of trees within which crosses are made to generate material for the next cycle } \\
\text { of selection. Breeding populations are generally large, as compared to the production } \\
\text { population. }\end{array}$ \\
\hline Breeding region & $\begin{array}{l}\text { A geographic area, defined mainly by adaptation criteria, for which Stream } 2 \\
\text { materials are selected, bred, tested, multiplied and deployed. }\end{array}$ \\
\hline Breeding rights & $\begin{array}{l}\text { The right to use genetic materials for one or more generations of crossing, genetic } \\
\text { testing and selection. These rights are usually exercised by tree breeders to produce } \\
\text { successive generations of improved materials. }\end{array}$ \\
\hline $\begin{array}{l}\text { Breeding value } \\
\text { (BV) }\end{array}$ & $\begin{array}{l}\text { The genetic value of an individual for a given trait, based on the mean performance } \\
\text { of its offspring or other relatives. BV may be expressed in terms of measurement } \\
\text { units such as } \mathrm{m} \text { or } \mathrm{cm} \text {; it is more commonly expressed in relative terms, as a percent } \\
\text { deviation from the population mean. }\end{array}$ \\
\hline $\begin{array}{l}\text { Collections, } \\
\text { public land }\end{array}$ & $\begin{array}{l}\text { Genetic material gathered and removed from public land for the purposes of } \\
\text { reforestation, breeding or research. It does not include collections from approved } \\
\text { production facilities. }\end{array}$ \\
\hline $\begin{array}{l}\text { Controlled } \\
\text { parentage } \\
\text { program } \\
\text { (CPP) }\end{array}$ & $\begin{array}{l}\text { A stock production program that includes in its population a finite number of } \\
\text { deliberately chosen individuals. Production of deployment stock for the program } \\
\text { occurs in a production facility (such as a seed orchard or stoolbed) where parents are } \\
\text { propagated vegetatively or sexually. }\end{array}$ \\
\hline Crop & $\begin{array}{l}\text { Aggregate of cones, seeds or vegetative propagules intended to be registered under a } \\
\text { single registered lot number. }\end{array}$ \\
\hline $\begin{array}{l}\text { Cumulative } \\
\text { effective } \\
\text { population } \\
\text { size }\end{array}$ & $\begin{array}{l}\text { The effective population size (Ne) of the output of a production facility or facilities, } \\
\text { or of material deployed from that facility or facilities, calculated over years and/or } \\
\text { across production facilities, for a given breeding region or deployment zone. See } \\
\text { Appendix } 20 \text { for calculation method. }\end{array}$ \\
\hline Cumulative $\mathrm{Ne}$ & See "Cumulative effective population size." \\
\hline Deployment & $\begin{array}{l}\text { Establishment of a new crop through artificial regeneration; through physical } \\
\text { movement from one site (e.g. a nursery) to the deployment site; or through planting } \\
\text { or seeding designed to meet resource management objectives or obligations. } \\
\text { Afforestation, reclamation and reforestation may be considered to be deployment. } \\
\text { Natural regeneration, even where enhanced through silvicultural techniques such as } \\
\text { scarification, is not considered to be deployment. }\end{array}$ \\
\hline
\end{tabular}




\begin{tabular}{|c|c|}
\hline Term & Definition \\
\hline $\begin{array}{l}\text { Deployment } \\
\text { zone }\end{array}$ & $\begin{array}{l}\text { A geographic area, defined mainly by adaptation criteria, for which Stream } 2 \\
\text { material is produced. Deployment zones include breeding regions. }\end{array}$ \\
\hline Dioecious & $\begin{array}{l}\text { Refers to a species in which male and female "flowers" generally occur on different } \\
\text { plants; thus each plant is usually either male or female, but not both; e.g. aspen } \\
\text { (Populus tremuloides). }\end{array}$ \\
\hline $\begin{array}{l}\text { Effective } \\
\text { population } \\
\text { size (Ne) }\end{array}$ & $\begin{array}{l}\text { Effective population size }(\mathrm{Ne}) \text { is one measure of genetic diversity and relatedness in a } \\
\text { seed or vegetative lot, and reflects both the degree of relatedness among parents and } \\
\text { the degree of balance among parental contributions to the given lot. }\end{array}$ \\
\hline $\begin{array}{l}\text { Effective } \\
\text { population } \\
\text { size, } \\
\text { cumulative } \\
\end{array}$ & See "Cumulative effective population size." \\
\hline Genetic gain & $\begin{array}{l}\text { The average heritable change attributable to selection in a given trait, from one } \\
\text { generation to the next. }\end{array}$ \\
\hline Genetic identity & $\begin{array}{l}\text { One of several unambiguous current or historical identifiers of seed or vegetative } \\
\text { material lots that can be used to identify the genetic source of material in a trial. The } \\
\text { unique identifier, accession number or registered lot number may be used. }\end{array}$ \\
\hline $\begin{array}{l}\text { Genetic } \\
\text { research } \\
\text { planting }\end{array}$ & $\begin{array}{l}\text { A planting associated with a research plan or controlled parentage plan. All } \\
\text { materials in genetic research plantings must be Stream } 1 \text { materials, Stream } 2 \\
\text { materials, local research materials or non-local research materials, and must be } \\
\text { registered or have a material identity. }\end{array}$ \\
\hline Genetic worth & $\begin{array}{l}\text { For a seed or vegetative lot, the predicted difference in value of a given trait (e.g. } \\
\text { height or volume) from the value of that trait in wild stand material. }\end{array}$ \\
\hline $\begin{array}{l}\text { Genetically } \\
\text { modified } \\
\text { organism } \\
\text { (GMO) }\end{array}$ & $\begin{array}{l}\text { An organism that, through human intervention in a laboratory, has had its genome, or } \\
\text { genetic code, deliberately altered through the insertion of a specific identified } \\
\text { sequence of genetic coding material (generally DNA) that has been either } \\
\text { manufactured or physically excised from the genome of another organism. Genetic } \\
\text { modification may be used to alter any of a wide range of traits, including insect and } \\
\text { disease resistance, herbicide tolerance, tissue composition and growth rate. }\end{array}$ \\
\hline Genotype & $\begin{array}{l}\text { The genetic identity or constitution of an individual. Physical material, in the form of } \\
\text { plant tissue, provides the medium for storage and transmission of a genotype. }\end{array}$ \\
\hline Green Area & $\begin{array}{l}\text { The area outlined and colored green on a map annexed to the Order Classifying } \\
\text { Public Lands dated April 16,1963, and published in The Alberta Gazette on April } \\
\text { 30, 1963, as amended from time to time. The Green Area includes public land that is } \\
\text { primarily forested, and is managed for timber production, oil/gas development, } \\
\text { watershed, wildlife and fisheries, recreation and other uses. }\end{array}$ \\
\hline Hybrid orchard & $\begin{array}{l}\text { An orchard including non-hybrid parents that is managed to produce hybrid seed. } \\
\text { This term does not apply to orchards that include naturally occurring hybrid parents } \\
\text { (e.g. Sw x Se). }\end{array}$ \\
\hline $\begin{array}{l}\text { Intellectual } \\
\text { property } \\
\text { rights }\end{array}$ & $\begin{array}{l}\text { The rights to intangible property that is the product of the human intellect. } \\
\text { Intellectual property may be protected by copyright, trademark or patent. The holder } \\
\text { of intellectual property rights is usually the person or persons who developed the } \\
\text { product or the organization that funded it. In the context of Forest Genetic Policy, } \\
\text { intellectual property rights apply to genetic data and to the genotypes to which they } \\
\text { apply, either separately or in aggregate. }\end{array}$ \\
\hline
\end{tabular}




\begin{tabular}{|c|c|}
\hline Term & Definition \\
\hline $\begin{array}{c}\text { Local research } \\
\text { material }\end{array}$ & See "Research material, local." \\
\hline $\begin{array}{l}\text { Locally adapted } \\
\text { material }\end{array}$ & $\begin{array}{l}\text { Material from, or derived from, the seed zone or breeding region in question. } \\
\text { Locally adapted material may be one of: } \\
\text { 1. Stream } 1 \text { material collected from within the seed zone in which deployment is } \\
\text { planned } \\
\text { 2. Stream } 2 \text { material collected from a production facility associated with a } \\
\text { controlled parentage program for the breeding region within which deployment } \\
\text { is planned } \\
\text { 3. research material collected from a breeding region (or, in some cases, adjacent } \\
\text { breeding regions) for inclusion in a controlled parentage program for the } \\
\text { deployment zone within which deployment is planned }\end{array}$ \\
\hline $\begin{array}{c}\text { Lot number, } \\
\text { registered }\end{array}$ & $\begin{array}{l}\text { A number used to uniquely identify a seed or vegetative lot through to storage, } \\
\text { deployment and monitoring. The registered lot number is assigned by the Department } \\
\text { when material is registered. }\end{array}$ \\
\hline $\begin{array}{r}\text { Lot number, } \\
\text { temporary }\end{array}$ & A number used to uniquely identify a seed or vegetative lot prior to registration. \\
\hline $\begin{array}{l}\text { Material } \\
\text { transfer } \\
\text { agreement } \\
\text { (MTA) }\end{array}$ & $\begin{array}{l}\text { Material transfer agreements (MTAs) are contractual legal agreements between two } \\
\text { or more parties governing the transfer and subsequent use of genetic materials. } \\
\text { MTAs specify which rights are conferred, and may contain clauses concerning such } \\
\text { topics as record keeping, reclaim rights, liability disclaimers and prohibitions on use } \\
\text { of the material for further breeding. }\end{array}$ \\
\hline $\begin{array}{l}\text { Material use } \\
\text { rights }\end{array}$ & $\begin{array}{l}\text { The right to use genetic materials (e.g. seeds, seedlings, somatic seedlings or rooted } \\
\text { cuttings) for plantation purposes. The holder of material use rights does not usually } \\
\text { have propagation or breeding rights. }\end{array}$ \\
\hline Monoecious & $\begin{array}{l}\text { Refers to a species in which male and female "flower" parts generally occur on the } \\
\text { same plant, either within a single "flower" or separately; thus each plant is usually } \\
\text { both male and female; e.g. white spruce (Picea glauca). }\end{array}$ \\
\hline $\mathrm{Ne}$ & See "Effective population size." \\
\hline $\begin{array}{l}\text { Non-local } \\
\text { material }\end{array}$ & $\begin{array}{l}\text { Material of unknown adaptation. } \\
\text { Any of: } \\
\text { 1. wild material collected from outside the seed zone in which deployment is } \\
\text { proposed, } \\
\text { 2. controlled parentage program material collected from a production facility not } \\
\text { associated with the deployment zone within which deployment is proposed, or } \\
\text { 3. material from outside the given deployment zone, under evaluation for } \\
\text { adaptation. }\end{array}$ \\
\hline $\begin{array}{l}\text { Non-local } \\
\text { research } \\
\text { material }\end{array}$ & See "Research material, non-local." \\
\hline
\end{tabular}




\begin{tabular}{|c|c|}
\hline Term & Definition \\
\hline Pedigree & $\begin{array}{l}\text { A record of parentage, sometimes also including data on the performance of parents } \\
\text { and other relatives. }\end{array}$ \\
\hline $\begin{array}{l}\text { Plants with } \\
\text { Novel Traits }\end{array}$ & $\begin{array}{l}\text { A plant variety/genotype possessing characteristics that demonstrate neither } \\
\text { familiarity nor substantial equivalence to those present in a distinct, stable population } \\
\text { of a cultivated species of seed in Canada and that have been intentionally selected, } \\
\text { created or introduced into a population of that species through a specific genetic } \\
\text { change. } \\
\text { In this definition, familiarity means, the knowledge of the characteristics of a plant } \\
\text { species and experience with the use of that plant species in Canada and substantial } \\
\text { equivalence means, the equivalence of a novel trait within a particular plant species, } \\
\text { in terms of its specific use and safety to the environment and human health, to those } \\
\text { in that same species, that are in use and generally considered as safe in Canada, } \\
\text { based on valid scientific rationale. }\end{array}$ \\
\hline $\begin{array}{l}\text { Production } \\
\text { facility }\end{array}$ & $\begin{array}{l}\text { An entity such as a seed orchard, stoolbed, hedge or laboratory where Stream } 2 \text { seed } \\
\text { or vegetative material is produced for deployment through sexual reproduction or } \\
\text { vegetative propagation. }\end{array}$ \\
\hline $\begin{array}{c}\text { Production } \\
\text { population }\end{array}$ & $\begin{array}{l}\text { The population of trees that produces seeds or cuttings for stock production for } \\
\text { deployment. This will generally be a subset of the base population, or of the } \\
\text { breeding population if one exists, and may or may not be intensively selected. The } \\
\text { production population is usually much smaller than the breeding population. }\end{array}$ \\
\hline Public land & $\begin{array}{l}\text { Alberta "public lands" as defined in the Public Lands Act. Includes Green Area (land } \\
\text { managed primarily as forest land) and White Area (land managed primarily for } \\
\text { agriculture and uses other than forestry). }\end{array}$ \\
\hline $\begin{array}{c}\text { Public land } \\
\text { collections }\end{array}$ & See "Collections, public land." \\
\hline Ramet & $\begin{array}{l}\text { An individual that has been vegetatively reproduced from the original plant, or ortet, } \\
\text { and is thus genetically identical to it. }\end{array}$ \\
\hline Ramet, grafted & $\begin{array}{l}\text { A ramet created by grafting a twig or bud from the original plant onto a physically } \\
\text { distinct rootstock. The portion of the grafted ramet above the graft union is } \\
\text { genetically identical to the original plant (See also "Ramet, rooted.") }\end{array}$ \\
\hline Ramet, rooted & $\begin{array}{l}\text { A ramet created by rooting a twig or cutting from the original plant. The whole ramet } \\
\text { is genetically identical to the original plant (See also, "Ramet, grafted.") }\end{array}$ \\
\hline Reclamation & $\begin{array}{l}\text { A planned series of activities designed to recreate the biophysical capacity of an } \\
\text { ecosystem. }\end{array}$ \\
\hline Reforestation & $\begin{array}{l}\text { The reestablishment of trees on denuded forest land by natural or artificial means } \\
\text { such as planting and seeding. }\end{array}$ \\
\hline $\begin{array}{l}\text { Registered lot } \\
\text { number }\end{array}$ & See "Lot number, registered." \\
\hline Registration & $\begin{array}{l}\text { Process that allows a seed or vegetative lot to be used for deployment within its } \\
\text { deployment zone or seed zone. Only Stream } 1 \text { and Stream } 2 \text { materials can be } \\
\text { registered. Registration may be restricted or unrestricted. A registered seed or } \\
\text { vegetative lot is one that has completed the registration process. }\end{array}$ \\
\hline $\begin{array}{r}\text { Registration, } \\
\text { unrestricted }\end{array}$ & See "Unrestricted registration." \\
\hline
\end{tabular}




\begin{tabular}{|c|c|}
\hline Term & Definition \\
\hline $\begin{array}{c}\text { Registration, } \\
\text { restricted }\end{array}$ & See "Restricted registration." \\
\hline $\begin{array}{l}\text { Research } \\
\text { material, } \\
\text { local }\end{array}$ & $\begin{array}{l}\text { Seed or vegetative materials from within the target breeding region or an adjacent } \\
\text { breeding region that may not be eligible for registration (e.g. an open-pollinated } \\
\text { seedlot collected from a single tree). These materials may be included in a controlled } \\
\text { parentage program leading to production of Stream } 2 \text { material. These materials must } \\
\text { have an assigned unique identifier before being established in genetic research } \\
\text { plantings or a controlled parentage program. The Breeding, Testing and Verification } \\
\text { Standards apply to this material. }\end{array}$ \\
\hline $\begin{array}{l}\text { Research } \\
\text { material, } \\
\text { non-local }\end{array}$ & $\begin{array}{l}\text { Seed or vegetative materials of unknown adaptation (such as species, provenance, } \\
\text { family or hybrid material from outside the seed zone or breeding region of origin). } \\
\text { Untested non-local research materials are not eligible for deployment within the } \\
\text { Green Area, or inclusion in production facilities associated with controlled } \\
\text { parentage programs (with some exceptions of material from adjacent breeding } \\
\text { regions), but may be included in genetic research plantings. These materials must } \\
\text { have an assigned unique identifier before being established in genetic research } \\
\text { plantings. Following testing and demonstration of adaptedness, these materials may } \\
\text { be included in controlled parentage programs leading to production of Stream } 2 \\
\text { materials. The Breeding, Testing and Verification Standards apply to this material. }\end{array}$ \\
\hline $\begin{array}{l}\text { Restricted } \\
\text { registration }\end{array}$ & $\begin{array}{l}\text { Material registration category that does not allow unrestricted deployment. A } \\
\text { limitation may be imposed on area or amount of material deployed, and/or } \\
\text { monitoring requirements. Registration may be restricted for reasons of: } \\
\text { - undetermined genetic or ecological risk } \\
\text { - incomplete documentation, or } \\
\text { - insufficient diversity levels, as indicated by effective population size, Ne. }\end{array}$ \\
\hline $\begin{array}{l}\text { Rolling front } \\
\text { orchard }\end{array}$ & $\begin{array}{l}\text { A seed orchard in which individual trees or groups of trees of known breeding value } \\
\text { are replaced on a more or less continuous basis as new material of higher breeding } \\
\text { value becomes available. }\end{array}$ \\
\hline Seed orchard & $\begin{array}{l}\text { A stand of trees, usually several hundred to several thousand in number, established } \\
\text { and managed primarily for early and abundant production of seed for deployment. } \\
\text { Trees in the orchard are derived and propagated from selected parent trees by } \\
\text { grafting or by seed. }\end{array}$ \\
\hline Seed zone & $\begin{array}{l}\text { A geographic area, defined on the basis of ecological characteristics and genetic } \\
\text { information, within which Stream } 1 \text { material meeting unrestricted registration } \\
\text { requirements may be collected and freely deployed. Seed zones may apply to groups } \\
\text { of species, or species-specific seed zones may be developed. }\end{array}$ \\
\hline $\begin{array}{l}\text { Serial } \\
\text { propagation }\end{array}$ & $\begin{array}{l}\text { The propagation of multiple clonal copies of a plant through repeated cycles of } \\
\text { collection of vegetative units (e.g. scions or cuttings), creation of new plants from } \\
\text { these units, and vegetative growth of the derived plants, without returning to the } \\
\text { original plant. Also known as "bulking up" or multiplication. }\end{array}$ \\
\hline $\begin{array}{l}\text { Species-specific } \\
\text { seed zone }\end{array}$ & $\begin{array}{l}\text { A seed zone, delineated for a single species on the basis of adaptation as assessed } \\
\text { from genetic trials, within which Stream } 1 \text { material may be collected and freely } \\
\text { deployed. }\end{array}$ \\
\hline
\end{tabular}




\begin{tabular}{|c|c|}
\hline Term & Definition \\
\hline Stoolbed & $\begin{array}{l}\text { An aggregation of closely spaced stumps, or stools, managed for the production of } \\
\text { one-year-old vegetative sprouts (whips). Harvested whips are used for operational } \\
\text { planting stock and can be pre-rooted prior to deployment. }\end{array}$ \\
\hline $\begin{array}{c}\text { Stream } 1 \\
\text { material }\end{array}$ & $\begin{array}{l}\text { Adapted seed or vegetative material collected from wild or artificially regenerated } \\
\text { stands of native species within a given seed zone, having restricted or unrestricted } \\
\text { registration for deployment in that seed zone. Adaptedness of Stream } 1 \text { material is } \\
\text { assumed on the basis of limited geographic transfer from source location. Diversity } \\
\text { and documentation standards apply. The Materials Collection, Handling, } \\
\text { Registration and Storage Standards and the Green Area Deployment Standards apply } \\
\text { to this material (see Appendix 6). }\end{array}$ \\
\hline $\begin{array}{c}\text { Stream } 2 \\
\text { material }\end{array}$ & $\begin{array}{l}\text { Adapted seed or vegetative material produced in a production facility, having } \\
\text { restricted or unrestricted registration for deployment within the deployment zone of } \\
\text { the associated controlled parentage program. Diversity and documentation standards } \\
\text { apply. Adaptedness of Stream } 2 \text { material is assumed on the basis of limited } \\
\text { geographic transfer from source location, or may be confirmed through long-term } \\
\text { testing and/or monitoring, concurrent with use. Stream } 2 \text { material is derived from } \\
\text { material collected within the target deployment zone or, in some cases, from adjacent } \\
\text { areas or from material demonstrating adaptedness. Other material may be included in } \\
\text { programs producing Stream } 2 \text { material following testing and demonstration of } \\
\text { adaptedness (see "Research material, non-local"). All genetics policies apply to } \\
\text { Stream } 2 \text { material (see Appendix 6). }\end{array}$ \\
\hline $\begin{array}{l}\text { Temporary lot } \\
\text { number }\end{array}$ & See "Lot number, temporary." \\
\hline Test & $\begin{array}{l}\text { A genetic research planting designed to address a given genetic issue; may stand } \\
\text { alone or may be one planting of a series including the same or overlapping material; } \\
\text { e.g. a single progeny test site. Used interchangeably with trial. }\end{array}$ \\
\hline Test series & $\begin{array}{l}\text { A group of genetic research plantings of the same or overlapping material, on one or } \\
\text { several sites, designed to address a given genetic issue; e.g. a progeny test } \\
\text { established on four sites. Used interchangeably with trial series. }\end{array}$ \\
\hline Trial & $\begin{array}{l}\text { A genetic research planting designed to address a given genetic issue; may stand } \\
\text { alone or may be one planting of a series including the same or overlapping material; } \\
\text { e.g. a single progeny trial site. Used interchangeably with test. }\end{array}$ \\
\hline Trial series & $\begin{array}{l}\text { A group of genetic research plantings of the same or overlapping material, on one or } \\
\text { several sites, designed to address a given genetic issue; e.g. a progeny trial } \\
\text { established on four sites. Used interchangeably with test series. }\end{array}$ \\
\hline $\begin{array}{l}\text { Unique } \\
\text { identifier }\end{array}$ & $\begin{array}{l}\text { An alphanumeric code of } 7 \text { to } 13 \text { characters assigned to genetic material. The first } \\
\text { seven characters of the unique identifier are essential, and uniquely identify the } \\
\text { genotype by agency and sequence number. Subsequent characters may be included } \\
\text { as applicable, and specify material type (e.g. scions or pollen), individual number } \\
\text { (e.g. cutting 103), and species (e.g. Sw). A unique identifier is required for all } \\
\text { unregistered material included in research trials related to controlled parentage } \\
\text { programs. See Appendix } 25 \text { for details of variables, structure and agency codes. }\end{array}$ \\
\hline $\begin{array}{c}\text { Unrestricted } \\
\text { registration }\end{array}$ & $\begin{array}{l}\text { Registration that allows a seed or vegetative lot to be used freely for deployment } \\
\text { within its deployment zone or seed zone, without extraordinary monitoring } \\
\text { requirements or other restrictions. }\end{array}$ \\
\hline
\end{tabular}




\begin{tabular}{|l|l|}
\hline Term & Definition \\
\hline $\begin{array}{r}\text { Validated raw } \\
\text { data }\end{array}$ & $\begin{array}{l}\text { Raw data that has been examined and corrected for format, unambiguous errors and } \\
\text { omissions, and credibility. Validation is now largely conducted during the data } \\
\text { collection phase by programming the data logger to detect such anomalies as } \\
\text { shrinking trees, trees that are too tall for the given Diameter at Breast Height (DBH) } \\
\text { and live trees that were previously reported dead. }\end{array}$ \\
\hline White Area & $\begin{array}{l}\text { Private and public land in the settled portion of the province, managed primarily for } \\
\text { agriculture use, but not excluding other uses such as timber, oil/gas development, } \\
\text { recreation, soil and water conservation, and fish and wildlife habitat. }\end{array}$ \\
\hline Wild & Genetic materials of native species originating from natural regeneration. \\
\hline
\end{tabular}




\section{LIST OF ACRONYMS}

\begin{tabular}{|l|l|}
\hline AAC & Annual Allowable Cut \\
\hline ARIS & Alberta Regeneration Information System \\
\hline ATISC & Alberta Tree Improvement and Seed Centre \\
\hline BTV & Breeding, Testing and Verification section of the standards \\
\hline BV & Breeding Value \\
\hline CNT & Consultative Notation \\
\hline CPP & Controlled Parentage Program \\
\hline DBH & Diameter at Breast Height \\
\hline DFMP & Detailed Forest Management Plan \\
\hline FHT & Fall Height measurement \\
\hline FOIP & Freedom Of Information and Protection of Privacy Act \\
\hline FMA & Forest Management Agreement \\
\hline GAD & Green Area Deployment section of the standards \\
\hline GMO & Genetically Modified Organism \\
\hline GW & Genetic Worth \\
\hline G\&Y & Growth and Yield \\
\hline ISP & Industrial Sample Plot designation \\
\hline MCHRS & Material Collection, Handling, Registration and Storage section of the standards \\
\hline MLL & Miscellaneous Lease \\
\hline Ne & Effective population size \\
\hline ODA & Ownership and Data Access section of the standards \\
\hline OGR & Operating Ground Rules \\
\hline PCPM & Production of Controlled Parentage Material section of the standards \\
\hline PNT & Plant with Novel Traits \\
\hline PST & Permanent Sample Tree \\
\hline RP & Research Program \\
\hline SRD & Sustainable Resource Development Department \\
\hline TFA & Temporary Field Authority \\
\hline TSA & Timber Supply Analysis \\
\hline UTM & Universal Transverse Mercator \\
\hline
\end{tabular}




\section{LIST OF APPENDICES}

\begin{tabular}{|c|c|}
\hline Appendix Number and Title & Page \\
\hline 1. Flow Diagram for Registration and Deployment of Stream 2 Material & 37 \\
\hline 2. Registration Request Form - Stream 1 & 39 \\
\hline 3. Registration Request Form - Stream 2 & 41 \\
\hline 4. Collection Requirements for Registration of Stream 1 Material & 42 \\
\hline 5. Collection Requirements for Registration of Stream 2 Material & 43 \\
\hline 6. Stream Categories and ARIS Codes for Genetic Material & 44 \\
\hline 7. Seed Zone Descriptions, Areas and Maps & 46 \\
\hline 8. Request for Deployment Variance for Stream 1 Material & 52 \\
\hline 9. Assessment of Risk for Stream 2 Material & 53 \\
\hline 10. Temporary Field Authorization Form & 55 \\
\hline 11. Parent Tree Selection Form - Wild Stands and Plantations & 56 \\
\hline 12. Parent Tree Selection Form - Genetic Tests & 57 \\
\hline $\begin{array}{l}\text { 13. Decision Tree for Transfer of Stream } 1 \text { Material Outside the Seed Zone of } \\
\text { Origin }\end{array}$ & 58 \\
\hline $\begin{array}{l}\text { 14. Stream } 1 \text { Seedling and Vegetative Propagule Lot Deployment Limit by Seed } \\
\text { Zone }\end{array}$ & 59 \\
\hline 15. Documentation Form for Non-Local Material & 60 \\
\hline 16. Transportation or Storage of Research or CPP Parent Material Form & 61 \\
\hline $\begin{array}{l}\text { 17. Alberta Reforestation Seed and Vegetative Materials Withdrawal and } \\
\text { Transportation Form }\end{array}$ & 62 \\
\hline 18. Controlled Parentage Program Plan - Contents & 63 \\
\hline $\begin{array}{l}\text { 19. Breeding Regions and Deployment Zones and Associated Programs as of } \\
\text { May } 1,2002\end{array}$ & 66 \\
\hline 20. Cumulative Ne Across Production Facilities and/or Production Years & 73 \\
\hline 21. Total Production Facility Limit for Stream 2 Material & 76 \\
\hline 22. Request for Deployment Variance for Stream 2 Material & 77 \\
\hline 23. Request for Planting Variance for Research Material & 78 \\
\hline 24. Research Program Plan - Contents & 79 \\
\hline 25. Unique Identifier Codes & 80 \\
\hline 26. Genetic Test Establishment Report - Contents & 84 \\
\hline 27. Genetic Test Measurement Report - Contents & 86 \\
\hline 28. Genetic Test Analysis Report - Contents & 87 \\
\hline 29. Genetic Test Site Information Form & 88 \\
\hline 30. Example of Data Collection Map and Corresponding Form & 89 \\
\hline 31. Calculation of Genetic Worth for Vegetative Lots and Orchard Seedlots & 91 \\
\hline 32. Production Facility Establishment Report and Updates & 95 \\
\hline 33. Permanent Sample Tree (PST) Protocols & 97 \\
\hline 34. Pollen Contamination and Phenology Monitoring & 99 \\
\hline 35. Production Facility Annual Operations Report & 104 \\
\hline $\begin{array}{l}\text { 36. Calculation of Effective Population Size }(\mathrm{Ne}) \text { for Vegetative Lots and } \\
\text { Orchard Seedlots }\end{array}$ & 106 \\
\hline 37. Sampling Levels for Calculation of Ne Values in Orchard Seedlots & 112 \\
\hline
\end{tabular}




\section{Appendix 1. Flow Diagram for Registration and Deployment of Stream 2}

Material

See Standards 5.0, 18.4.1 and 25.1.

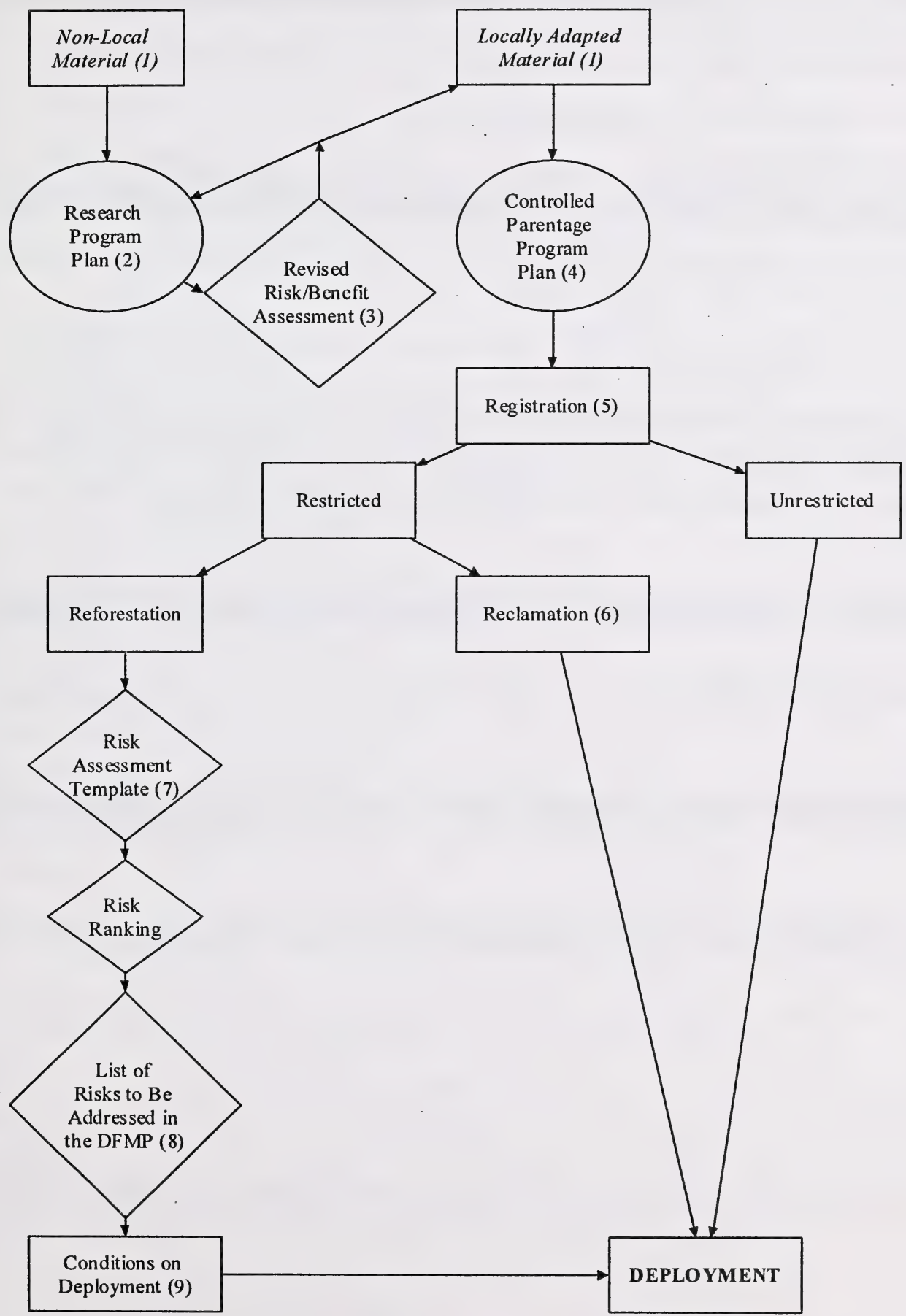


Appendix 1 (continued). Flow Diagram for Registration and Deployment of Stream 2 Material

${ }^{i}$ See Glossary for definitions. Note that some material originally classified as having unproven adaptation may be considered to be locally adapted after research results are available.

${ }^{2}$ Appendix 24. Research Program Plan - Contents

${ }^{3}$ The risk/benefit assessment conducted as a part of the Research Plan will be revised on the basis of information resulting from implementation of the Research Plan.

${ }^{4}$ Appendix 18. Controlled Parentage Program Plan - Contents

${ }^{5}$ Appendix 5. Collection Requirements for Registration. Also, MCHRS standards.

${ }^{6}$ See Standards of the Department of Environment for reclamation plantings.

${ }^{7}$ Appendix 9. Assessment of Risk for Stream 2 Material

${ }^{8}$ Where "Classes of Risk" in the Risk Assessment Template are rated higher than "Low," the specific risks will be identified and listed in the DFMP.

${ }^{9}$ Options for accommodating risks include limits on area of deployment, establishment of buffers around plantations of restricted material, limits on the distance from where the wood will be used, requirements for an intermediate level ("pilot-scale") of deployment before deployment to specified area limits, agreements to prevent natural regeneration on areas occupied by material of restricted registration, etc. 


\title{
Appendix 2. Registration Request Form - Stream 1
}

\author{
See Standards 10.1, 10.4, 10.6, 10.12, 12.3.1, 13.4, 13.5, 15.4 .
}

\section{ALBERTA SUSTAINABLE RESOURCE DEVELOPMENT - STREAM 1 REGISTRATION REQUEST}

\section{ADMINISTRATIVE INFORMATION}

OWNER

ADDRESS

REGISTERED LOT NUMBER

SIMS INVENTORY NO. FOR OEPARTMENT USE ONLY REGISTRATION CATEGORY

$\square$ UNRESTRICTED

$\square$ RESTRICTED

$\square$ PENDHNGREGISTRATION* $>_{1}$

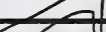

\section{STAND AND SITE INFORMATION}

SPECIES

TEMPORARY LOT NUMEER THE TEMPORARY IOT NUMBER IS ASSIGNED BY THE AGENCY AND MUST COCZS CEq

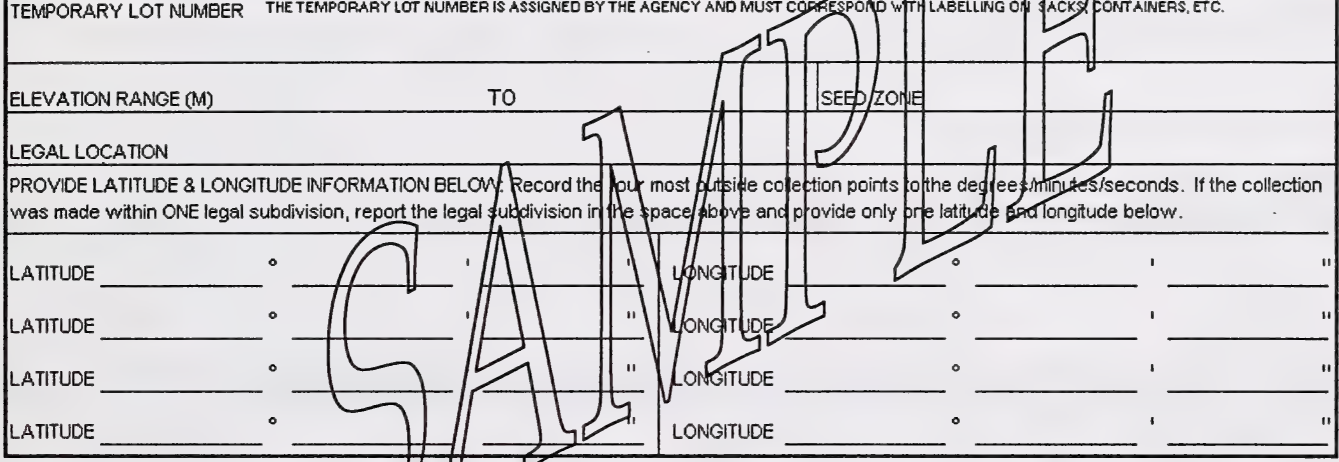

\section{COLLECTION INFORMATION}

COLLECTION SUPERVISOR

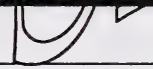

CONTRACTOR

COLLECTION METHOO

TYPE OF MATERIAL COLLECTED

AND TOTAL YOLUME ANDIOR AMOUNTS COLLECTED

COLLECTION DATES

NO. OF TREES SAMPLED

4. INTERIM STORAGE AND SHIPPING INFORMATION

INTERIM STORAGE DATES (INCLUDES COLD STORAGE)
DATE SHIPPED TO PROCESSING FACILITY

PROCESSING FACILITY

\section{EXTRACTION AND CLEANING INFORMATION (TO BE COMPLETED BY PROCESSIIG FACILITY FOR SEED OHLY)}

DATE RECEIVED

DATES EXTRACTED
AMOUNT CLEANED (KG)

SEED MOISTURE CONTENT

\begin{tabular}{|l|l|}
\hline IHEREGY DECLARE THAT THE INFORMATION GIVEN ABOVE (SECTIONS $1,2,3,8$ ) IS VALID AND CORRECT FOR THIS LOT. \\
\hline NAME & POSTION \\
\hline SIGNATURE & COMPANY \\
REMARKS & \\
\hline
\end{tabular}

A COPY OF THIS FORM MUST ACCOMPANY MATERIAL TO PROCESSING ANDIOR STORAGE FACILITIES IN COMPLIANCE WITH TM REGLLATION 144.3.

* Pending fulfillment of all requirements for registration such as adequate number of trees sampled. 


\section{INFORMATION FOR COMPLETING REGISTRATION REQUEST FORM - STREAM 1}

All forest tree seed and vegetative materials to be used on public land must be registered with the Department. Completion of this form initiates the registration process for materials collected on public land. The agency or company doing the collection assigns a temporary lot number, writes it on the tag with the material, and completes the Registration Request Form. The Department assigns a registered lot number once registration is complete.

\section{STAND AND SITE INFORMATION}

\section{ARIS Code}

Choose the most appropriate category as listed in Appendix 6.

\section{Temporary Lot Number}

Assign the lot a temporary number to track the material during processing prior to registration. The temporary lot number must correspond with the tag on the lot containers, e.g. cone sacks.

\section{Elevation}

The range between maximum and minimum elevation values in metres.

\section{COLLECTION INFORMATION}

\section{Collection method}

Choose the single, most appropriate, collection method:
Aerial
Climbing
Felled trees
Ground, ladder and/or hydraulic lift
Slash
Squirrel cache
Cuttings

Also record the picking method:

Hand picked Mechanically picked

\section{EXTRACTION/CLEANING AND SHIPPING INFORMATION}

Extraction information is to be completed by the processor. Moisture content is to be measured and recorded by the facility cleaning the seed. Only laboratory test results using International Seed Testing Association (ISTA) rules are acceptable and results must be expressed as a percentage by weight, calculated to one decimal place. (For seed testing guidelines see the Department's website).

Seed for shipping must be properly packaged to prevent transport damage. Each container must have a temporary lot number on a tag inside and one affixed to the outside.

\section{REMARKS}

Space is provided to record any additional stand, collection, handling or processing information. 


\section{Appendix 3. Registration Request Form - Stream 2}

See Standards 10.1, 10.4, 10.9, 10.12, 12.4.1, 13.4, 13.5.

\section{ALBERTA SUSTAINABLE RESOURCE DEVELOPMENT}

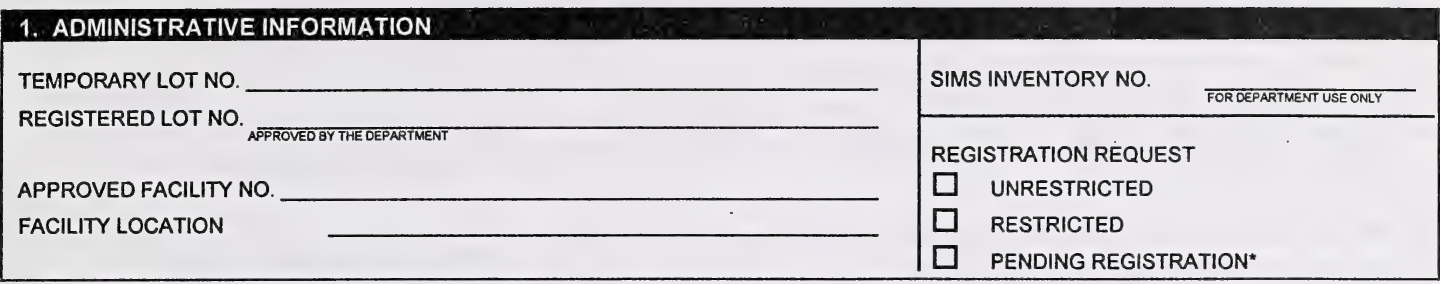

\begin{tabular}{|l|l|}
\hline 2. OWNERSHIP & \% OF LOT ALLOCATED \\
\hline COMPANY & \\
\hline & \\
\hline
\end{tabular}

\section{GENETIC INFORMATION}

SPECIES _ DEPLOYMENT ZONE

EFFECTIVE POPULATION SIZE

ARIS CODE (see Appendix 6)

\section{COLLECTION INFORMATION}

COLLECTION SUPERVISOR

COLLECTION METHOD

COLLECTION DATES
CONTRACTOR

TYPE OF MATERIAL COLLECTED AND TOTAL VOLUME AND/OR AMOUNTS COLLECTED

\section{INTERIM STORAGE AND SHIPPING INFORMATION}

INTERIM STORAGE DATES (INCLUDES COLD STORAGE)

DATE SHIPPED TO PROCESSING FACILITY

PROCESSING FACILITY

6. EXTRACTION AND CLEANING INFORMATION (TO BE COMPLETED BY PROCESSING FACILITY FOR SEED ONLY)

DATE RECEIVED

DATES EXTRACTED

AMOUNT CLEANED (KG)

SEED MOISTURE CONTENT

THE ABOVE INFORMATION (SECTIONS $1,2,3,4, \&$ ) WAS COMPLETED BY

NAME

POSITION

SIGNATURE

COMPANY

REMARKS

A COPY OF THIS FORM MUST ACCOMPANY LOTS TO PROCESSING AND/OR STORAGE FACILITIES IN COMPLIANCE WITH T/M REGULATION 144.3 


\section{Appendix 4. Collection Requirements for Registration of Stream 1 Material}

See Standards $10.4,10.6,10.8,10.12,11.4,18.2 .4,20.2$.

Location and parentage requirements for unrestricted registration of Stream 1 reforestation seed or vegetative material destined for deployment on Green Area public land are shown in the table below. Some collections not meeting these requirements may be eligible for restricted registration (see Appendix 2) or unrestricted registration as per conditions associated with superscripts 2, 3, 4 and 6 of the table. Lots that do not meet requirements for restricted registration (e.g. lots collected from fewer than the minimum number of trees specified below) may be collected and stored, pending fulfillment of registration requirements.

These guidelines and numerical limits on collection sizes were developed to safeguard genetic diversity by considering biological differences among species, patterns of natural variation, and quantitative implications of vegetative and sexual reproduction.

\begin{tabular}{|c|c|c|c|c|c|}
\hline $\begin{array}{l}\text { Material } \\
\text { Category }\end{array}$ & Stream 1 material $^{1}$ & $\begin{array}{l}\text { Minimum trees } \\
\text { per collection } \\
\text { for unrestricted } \\
\text { registration }\end{array}$ & $\begin{array}{l}\text { Maximum } \\
\text { elevation range } \\
\text { of trees } \\
\text { collected from }\end{array}$ & $\begin{array}{l}\text { Maximum } \\
\text { area from } \\
\text { which } \\
\text { collection is } \\
\text { made }^{4}\end{array}$ & $\begin{array}{l}\text { Maximum } \\
\text { amount of } \\
\text { material per } \\
\text { collection }\end{array}$ \\
\hline A & $\begin{array}{l}\text { All seedlot collections except } \\
\text { aspen }\end{array}$ & 30 & $100 \mathrm{~m}$ & $2 \mathrm{~km}$ radius $^{5}$ & See Appendix 14 \\
\hline B & Aspen seedlot collections & $\begin{array}{l}10 \text { (well-spaced } \\
\text { clones) }\end{array}$ & $100 \mathrm{~m}$ & $5 \mathrm{~km}$ radius $^{5}$ & See Appendix 14 \\
\hline C & $\begin{array}{l}\text { Vegetative lots (deployed without } \\
\text { serial propagation) }\end{array}$ & $75^{6}$ & $100 \mathrm{~m}$ & $5 \mathrm{~km}$ radius $^{5}$ & See Appendix 14 \\
\hline D & $\begin{array}{l}\text { Vegetative lots (serial propagation } \\
\text { before deployment) }\end{array}$ & $120^{6}$ & $100 \mathrm{~m}$ & $5 \mathrm{~km}$ radius $^{5}$ & See Appendix 14 \\
\hline
\end{tabular}

${ }^{1}$ Proponents are encouraged to make Stream 1 collections from wild stands within in situ conservation areas (see Standard 20.2) and adjoining areas to ensure that wild genetic resources are preserved.

${ }^{2}$ Lots from the same seed zone not meeting minimum standards for collection size may be combined to achieve required collection sizes for restricted or unrestricted registration, provided other registration requirements are met. For each of material categories A, B, C and D, lots collected from fewer than 20, 7, 75 and 75 trees respectively may be stored "pending registration" (see Appendix 2) and will only be registerable where so combined. Collection from numbers of trees between these numbers and the numbers shown in the table may be eligible for restricted registration.

${ }^{3}$ If collections span more than $100 \mathrm{~m}$ in elevational range, then deployment is limited to within the seed zone boundaries, and a request for deployment outside the seed zone of origin will not be approved.

${ }^{4}$ Deployment of collections made from an area larger than that described in this table will be limited to a total of 5 million seedlings/propagules per lot.

${ }^{5}$ If collections are made within the required radius in the table and within a $100 \mathrm{~m}$ elevational range, then material may be deployed up to $1 \mathrm{~km}$ outside the seed zone of origin, provided the difference in elevation from the point of collection to the point of deployment does not exceed $100 \mathrm{~m}$. These collections are also eligible for movement outside of the seed zone of origin through application for a request for deployment variance for Stream 1 material (see Appendix 8).

${ }^{6}$ Must be collected from trees separated by at least $10 \mathrm{~m}$. 


\section{Appendix 5. Collection Requirements for Registration Of Stream 2 Material}

See Standards 10.4, 10.9, 10.12 .

Effective population size (Ne) requirements for registration of Stream 2 reforestation seed or vegetative material destined for deployment on Green Area Public Land.

\begin{tabular}{|l|c|l|l|}
\hline \multicolumn{1}{|c|}{$\begin{array}{c}\text { Stream 2 } \\
\text { material }\end{array}$} & $\begin{array}{c}\text { Ne (effective } \\
\text { population size) }\end{array}$ & \multicolumn{1}{|c|}{$\begin{array}{c}\text { Registration } \\
\text { category }\end{array}$} & $\begin{array}{c}\text { Maximum deployable numbers } \\
\text { from a production facility }\end{array}$ \\
\hline Seed lots & $\geq 18^{1}$ & unrestricted & see Appendix 21 \\
\hline Vegetative lots & $\geq 18^{1,2}$ & unrestricted & see Appendix 21 \\
\hline Seed lots & $6-18^{3}$ & restricted & see Appendices $1,9 \& 21$ \\
\hline Vegetative lots & $6-18^{3}$ & restricted & see Appendices $1,9 \& 21$ \\
\hline Seed lots & $<6^{3,4}$ & pending registration & 0 \\
\hline Vegetative lots & $<6^{3,4}$ & pending registration & 0 \\
\hline
\end{tabular}

${ }^{1}$ See Appendix 36 for $\mathrm{Ne}$ calculation methods.

${ }^{2}$ For dioecious species, lots must derive from approximately equal numbers of male and female contributing clones.

${ }^{3}$ Lots with $\mathrm{Ne}<18$ may be combined to achieve threshold $\mathrm{Ne}$ levels of 6 and 18 for restricted and unrestricted registration respectively. Lots to be combined must be from a production facility targeting the same deployment zone.

${ }^{4}$ Lots with $\mathrm{Ne}<6$ may be held in interim storage, pending combination with other lot(s) to achieve registerable $\mathrm{Ne}$ levels. 


\section{Appendix 6. Stream Categories and ARIS Genetic Class ${ }^{1}$ Code for Genetic Material}

See Standards 10.7, 10.11, 33.6, 34.5.

\section{A. SEED}

I. List of Potential Materials for Deployment on Provincial Public Land

\section{Material Type}

a. Native seed collections from wild stands

1. Unselected parents from unselected stands

2. Unselected parents from selected stands

3. Selected parents from unselected stands

4. Selected parents from selected stands

b. Native seed collections from artificially regenerated stands

5. Unselected parents from unselected stands

6. Unselected parents from selected stands

7. Selected parents from unselected stands

8. Selected parents from selected stands

c. Seed collections from production facilities ${ }^{2}$

9. Improved orchard

10. Unimproved orchard

11. Seedlot with $\mathrm{Ne}<18$ (registration restricted) ${ }^{3}$

12. Hybrid orchard ${ }^{4}$

13. Non-local material

14. Genetically modified organisms (GMOs)
Stream ARIS Genetic Class Code

Ala1
Ala2
Ala3
Ala4

Alb5

Alb6

Alb7

Alb8

AIc9

AIc10

AIcl1

AIc12

AIcl3

AIc14

II. List of Potential Precursor Materials for Deployment on Provincial Public Land
a. Local seed
15. Individual family
$\mathrm{R}$
16. Pollen
$\mathrm{R}$
17. GMOs
$\mathrm{R}$

b. Non-local seed

18. Provenances

19. Species

$\mathrm{R}$

20. Hybrids

$\mathrm{R}$

21. Individual family

$\mathrm{R}$

22 Genetically modified organisms (GMOs)

$\mathrm{R}$

23. Pollen

$\mathrm{R}$

$\mathrm{R}$

Stream 1 = traditional reforestation stream (see glossary)

Stream 2 = controlled parentage stream (see glossary)

$\mathrm{R}=$ research material (see glossary)

\footnotetext{
${ }^{1}$ ARIS codes assigned only to Stream 1 and 2 materials; research materials cannot be deployed operationally.

${ }^{2}$ Orchards may include some trees from adjacent breeding regions/deployment zones.

${ }^{3}$ If material fits this category in addition to any other category, this category over-rides.

${ }^{4}$ Orchard designed to produce hybrid seed.
} 
I. List of Potential Materials for Deployment on Provincial Public Land

\section{Material Type}

a. Native propagule collections from wild stands

1. Unselected parents from unselected stands

2. Unselected parents from selected stands

3. Selected parents from unselected stands

4. Selected parents from selected stands

b. Native propagule collections from artificially regenerated stands

5. Unselected parents from unselected stands

6. Unselected parents from selected stands

7. Selected parents from unselected stands

8. Selected parents from selected stands

c. Propagules generated from production facilities

9. Selected population

10. Tested population

11. Lot with $\mathrm{Ne}<18$ (registration restricted) ${ }^{6}$

12. Amplified family

13. Hybrids $^{7}$

14. Non-local material

15. GMOs

\section{Stream ARIS Genetic Class Code}

BIal

BIa2

$\mathrm{BIa} 3$

BIa4

BIb5

BIb6

BIb7

BIb8

BIc9

BIc10

BIc11

BIc12

BIc13

BIc14

BIc15

\section{List of Potential Precursor Materials for Deployment on Provincial Public Land}

\section{a. Local material}

16. Individual family

$\mathrm{R}$

17. Individual clones

$\mathrm{R}$

18. Pollen

$\mathrm{R}$

19. GMOs

$\mathrm{R}$

b. Non-local material

20. Provenance material $R$

21. Species material $\mathrm{R}$

22. Hybrid material $R$

23. Individual clones $\quad \mathrm{R}$

24. Pollen $\mathrm{R}$

25. GMOs $\mathrm{R}$

Stream 1 = traditional reforestation stream (see glossary)

Stream 2 = controlled parentage stream (see glossary)

$\mathrm{R}=$ research material (see glossary)

\footnotetext{
${ }^{5}$ Materials may be multiplied in stoolbeds that meet the minimum number of trees required per collection for Stream 1 material (see Standard 11.4 and Appendix 4).

${ }^{6}$ If material fits this category in addition to any other category, this category over-rides.

${ }^{7}$ Hybrid with at least one non-local parent
} 


\title{
Appendix 7. Seed Zone Descriptions, Areas and Maps
}

\author{
See Standards 10.8, 18.2.1, 20.2.
}

Populations of forest tree species exhibit genetic variation associated with differences in the geography and climate of origin. Such variation is the result of long-term evolutionary processes and is key to biological adaptation to regional habitats and to maintenance of future evolutionary potential. For these reasons, movement of all seed to reforestation sites on public land is regulated.

\section{Seed Zones}

A seed zonation system for Alberta has been developed for natural seed movement and will replace the existing Seed Provenance Rule (deployment within a 50 mile radius and plus/minus 500 feet elevation movement from location of collection). Seed zones are geographic subdivisions of Natural Regions and Subregions and are based on general genetic criteria. They limit seed movement to a conservative area where native trees of all species can be moved without risk of mal-adaptation or erosion of genetic integrity. Seed collections from natural stands of all species within a seed zone meeting unrestricted registration requirements can be moved without restriction. There are a total of 90 described seed zones for Alberta, which cover all species and areas of the province. Seventy-four seed zones are applicable to the Green Area.

The Forestry Seed Zones of Alberta are delineated for all areas of Alberta and are inclusive for all native forest plant species. The intent of seed zones is to provide delineated ecological land units within which planning, collection, inventory maintenance, conservation and deployment can occur for reproductive materials of natural forest plant species, with emphasis on tree species.

Seed zone delineation is hierarchical, and based on Alberta's six Natural Regions, their Natural Subregions and Ecodistricts. Where there was a concern that the Natural Regions, Subregions or Ecodistricts did not adequately capture natural adaptive genetic variation, elevation contours were used for further subdivision.

Seed zone labeling is structured so that:

a. the designated alphabetic descriptor denotes the Natural Subregion which the seedzone falls in;

b. the number preceding the decimal designates groupings of seedzones within a subregion that are more similar in climate; and

c. the decimal portion designates the individual seed zone within a climate grouping and numbering generally follows a pattern of decreasing continentality.

The seed zones are listed in Table 1 and mapped in the three subsequent figures.

Seed zone delineation will be periodically reviewed and updated to incorporate any significant boundary changes to the Natural Regions, Natural Subregions or Ecodistricts.

For larger scale maps, contact the Public Lands and Forests Division of the Department. 
Table 1. Seed Zone Numbers, Areas and Names

\begin{tabular}{|c|c|c|c|}
\hline $\begin{array}{c}\text { SEEDZONE } \\
\text { LABEL }\end{array}$ & $\begin{array}{c}\text { AREA IN } \\
\text { HECTARES }\end{array}$ & NATURAL SUBREGION & SEED ZONE NAME \\
\hline A 1.1 & 341810.8 & Alpine & Kakwa-Athabasca Alpine \\
\hline A 1.2 & 572905.6 & Alpine & Athabasca-Kootenay Alpine \\
\hline A 1.3 & 491421.7 & Alpine & Kootenay-Bow Alpine \\
\hline A 1.4 & 86943.2 & Alpine & Bow-Crowsnest Alpine \\
\hline A 1.5 & 15371.2 & Alpine & Crownsest-Waterton Alpine \\
\hline AP 1.1 & 1352525.6 & Athabasca Plain & Athabasca Plain \\
\hline BSA 1.1 & 952530.5 & Boreal Subarctic & Caribou Mountains Boreal Subarctic Uplands \\
\hline BSA 1.2 & 229741.8 & Boreal Subartic & Cameron Hills Boreal Subarctic Uplands \\
\hline CM 1.1 & 1675648.5 & Central Mixedwood & Great Slave Central Mixedwood Plains \\
\hline CM 1.2 & 1209779.7 & Central Mixedwood & Vermillion Central Mixedwood Lowlands \\
\hline CM 1.3 & 1739402.7 & Central Mixedwood & Hay River Central Mixedwood Lowlands \\
\hline CM 2.1 & 1243579.2 & Central Mixedwood & Sakatchewan Central Mixedwood Plains \\
\hline CM 2.2 & 1384867.1 & Central Mixedwood & Mackay Central Mixedwood Lowlands \\
\hline CM 2.3 & 1103601.7 & Central Mixedwood & Loon Lake Central Mixedwood Lowlands \\
\hline CM 2.4 & 1786122.0 & Central Mixedwood & Wabasca Central Mixedwood Lowlands \\
\hline CM 3.1 & 2524587.7 & Central Mixedwood & Mostoos Hills Central Mixedwood Uplands \\
\hline CM 3.2 & 1301522.9 & Central Mixedwood & Swan Hills-Pelican Central Mixedwood Uplands \\
\hline CM 3.3 & 1402207.2 & Central Mixedwood & Swan Hills-Utikuma Central Mixedwood Uplands \\
\hline CM 3.4 & 992845.8 & Central Mixedwood & Wapiti-Smoky Central Mixedwood Uplands \\
\hline CM 3.5 & 421437.0 & Central Mixedwood & Drayton Central Mixedwood Plains \\
\hline CP 1.1 & 3487578.3 & Central Parkland & Northern Central Parkland Plains \\
\hline CP 1.2 & 1883038.0 & Central Parkland & Southern Central Parkland Plains \\
\hline DM 1.1 & 1476414.8 & Dry Mixedwood & Vermillion Dry Mixedwood Lowlands \\
\hline DM 1.2 & 1736061.1 & Dry Mixedwood & Peace River Dry Mixedwood Lowlands \\
\hline DM 1.3 & 1704193.5 & Dry Mixedwood & Smoky River Dry Mixedwood Lowlands \\
\hline DM 2.1 & 1138703.2 & Dry Mixedwood & Lac La Biche Dry Mixedwood Plains \\
\hline DM 2.2 & 1951238.3 & Dry Mixedwood & Edmonton Dry Mixedwood Plains \\
\hline DM 2.3 & 525542.8 & Dry Mixedwood & Red Deer Dry Mixedwood Plains \\
\hline DMG 1.1 & 4693718.1 & Dry Mixedgrass & Southeastern Dry Mixedgrass Plains \\
\hline FF 1.1 & 1362344.8 & Foothills Fescue & Southwestern Foothills Fescue \\
\hline FP 1.1 & 355167.2 & Foothills Parkland & Southwestern Foothills Parkland \\
\hline FP 1.2 & 37001.8 & Foothills Parkland & Waterton Foothills Parkland \\
\hline KU 1.1 & 971879.6 & Kazan Uplands & Kazan Upland \\
\hline LBH 1.1 & 624397.6 & Lower Boreal Highlands & Bistcho Lower Boreal Highlands \\
\hline LBH 1.2 & 469631.8 & Lower Boreal Highlands & Caribou Mountains Lower Boreal Highlands \\
\hline LBH 1.3 & 1042175.7 & Lower Boreal Highlands & Birch Mountains Lower Boreal Highlands \\
\hline LBH 1.4 & 595418.8 & Lower Boreal Highlands & Buffalo Head Hills Lower Boreal Highlands \\
\hline LBH 1.5 & 665699.1 & Lower Boreal Highlands & Stony Mountain Lower Boreal Highlands \\
\hline LBH 1.6 & 1985730.4 & Lower Boreal Highlands & Clear Hills Lower Boreal Highlands \\
\hline LBH 2.1 & 178449.6 & Lower Boreal Highlands & Cameron Hills Lower Boreal Highlands \\
\hline LF 1.1 & 253335.0 & Lower Foothills & Pelican Mountains Lower Foothills \\
\hline LF 1.2 & 295218.4 & Lower Foothills & Saddle Hills Lower Foothills \\
\hline LF 1.3 & 952135.0 & Lower Foothills & Swan Hills Lower Foothills \\
\hline LF 1.4 & 779499.8 & Lower Foothills & Wapiti-Athabasca Lower Foothills \\
\hline
\end{tabular}




\begin{tabular}{|c|c|c|c|}
\hline \begin{tabular}{|c|} 
SEEDZONE \\
LABEL
\end{tabular} & $\begin{array}{c}\text { AREA IN } \\
\text { HECTARES }\end{array}$ & NATURAL SUBREGION & SEED ZONE NAME \\
\hline LF 1.5 & 999586.3 & Lower Foothills & McLeod-North Saskatchewan Lower Foothills \\
\hline LF 2.1 & 663891.0 & Lower Foothills & Athabasca-McLeod Lower Foothills \\
\hline LF 2.2 & 335231.0 & Lower Foothills & Brazeau-Clearwater Lower Foothills \\
\hline LF 2.3 & 211005.0 & Lower Foothills & Clearwater-Bow Lower Foothills \\
\hline M 1.1 & 30947.5 & Montane & Cypress Hills Montane \\
\hline M 2.1 & 48420.3 & Montane & Grande Cache Montane \\
\hline M 2.2 & 33608.0 & Montane & Jasper Lower Montane \\
\hline M 3.2 & 94234.8 & Montane & Jasper Upper Montane \\
\hline M 4.1 & 17078.1 & Montane & Kootenay Lower Montane \\
\hline M 4.2 & 2170.1 & Montane & Ya Ha Tinda Montane \\
\hline M 4.3 & 71656.7 & Montane & Bow Lower Montane \\
\hline M 4.4 & 139315.8 & Montane & Bow-Porcupine Lower Montane \\
\hline M 4.5 & 137018.7 & Montane & Crowsnest Lower Montane \\
\hline M 5.1 & 25296.9 & Montane & Kootenay Upper Montane \\
\hline M5.3 & 77028.8 & Montane & Bow Upper Montane \\
\hline M 5.4 & 102078.3 & Montane & Bow-Old Man Upper Montane \\
\hline M 5.5 & 20759.1 & Montane & Porcupine Hills Upper Montane \\
\hline M 5.6 & 77161.1 & Montane & Crowsnest Waterton Upper Montane \\
\hline MG 1.1 & 1719775.7 & Mixedgrass & Western Mixedgrass Plains \\
\hline MG 1.2 & 38335.2 & Mixedgrass & Sweetgrass Mixedgrass Uplands \\
\hline MG 1.3 & 249065.5 & Mixedgrass & Cypress Hills Mixedgrass Uplands \\
\hline NF 1.1 & 1493334.8 & Northern Fescue & Northern Fescue Plains \\
\hline NM 1.1 & 2380309.9 & Northern Mixedwood & Great Slave Northern Mixedwood Plains \\
\hline NM 2.1 & 571010.5 & Northern Mixedwood & Bistcho Lake Northern Mixedwood Uplands \\
\hline PAD 1.1 & 553545.0 & Peace-Athabasca Delta & Peace-Athabasca Delta Plains \\
\hline PRP 1.1 & 312042.3 & Peace River Parkland & Peace River Parkland Lowlands \\
\hline SA 1.1 & 574366.7 & Subalpine & Wapiti-Athabasca Lower Subalpine \\
\hline SA 1.2 & 307193.1 & Subalpine & Athabasca-Kootenay Lower Subalpine \\
\hline SA 2.1 & 385373.6 & Subalpine & Wapiti-Athabasca Upper Subalpine \\
\hline SA 2.2 & 333915.4 & Subalpine & Athabasca-Kootenay Upper Subalpine \\
\hline SA 3.1 & 270422.0 & Subalpine & Kootenay-Bow Lower Subalpine \\
\hline SA 3.2 & 172154.3 & Subalpine & Bow-Crowsnest Lower Subalpine \\
\hline SA 3.3 & 65628.1 & Subalpine & Crowsnest-Waterton Lower Subalpine \\
\hline SA 4.1 & 232365.2 & Subalpine & Kootenay-Bow Upper Subalpine \\
\hline SA 4.2 & 139366.3 & Subalpine & Bow-Crowsnest Upper Subalpine \\
\hline SA 4.3 & 41063.9 & Subalpine & Crowsnest Waterton Upper Subalpine \\
\hline UBH 1.1 & 601181.3 & Upper Boreal Highlands & Birch Mountains Upper Boreal Highlands \\
\hline UBH 1.2 & 168899.6 & Upper Boreal Highlands & Buffalo Head Upper Boreal Highlands \\
\hline UBH 1.3 & 415742.6 & Upper Boreal Highlands & Clear Hills Upper Boreal Highlands \\
\hline UF 1.1 & 215721.1 & Upper Foothills & Swan Hills Upper Foothills \\
\hline UF 1.2 & 85115.6 & Upper Foothills & Mayberne Upper Foothills \\
\hline UF 1.3 & 912816.1 & Upper Foothills & Wapiti-Athabasca Upper Foothills \\
\hline UF 1.4 & 471903.8 & Upper Foothills & Athabasca-North Saskatchewan Upper Foothills \\
\hline UF 1.5 & 196392.0 & Upper Foothills & North Saskatchewan-Bow Upper Foothills \\
\hline UF 2.4 & 75246.8 & Upper Foothills & Brazeau Upper Foothills \\
\hline UF 2.5 & 196549.1 & Upper Foothills & Red Deer Upper Foothills \\
\hline
\end{tabular}




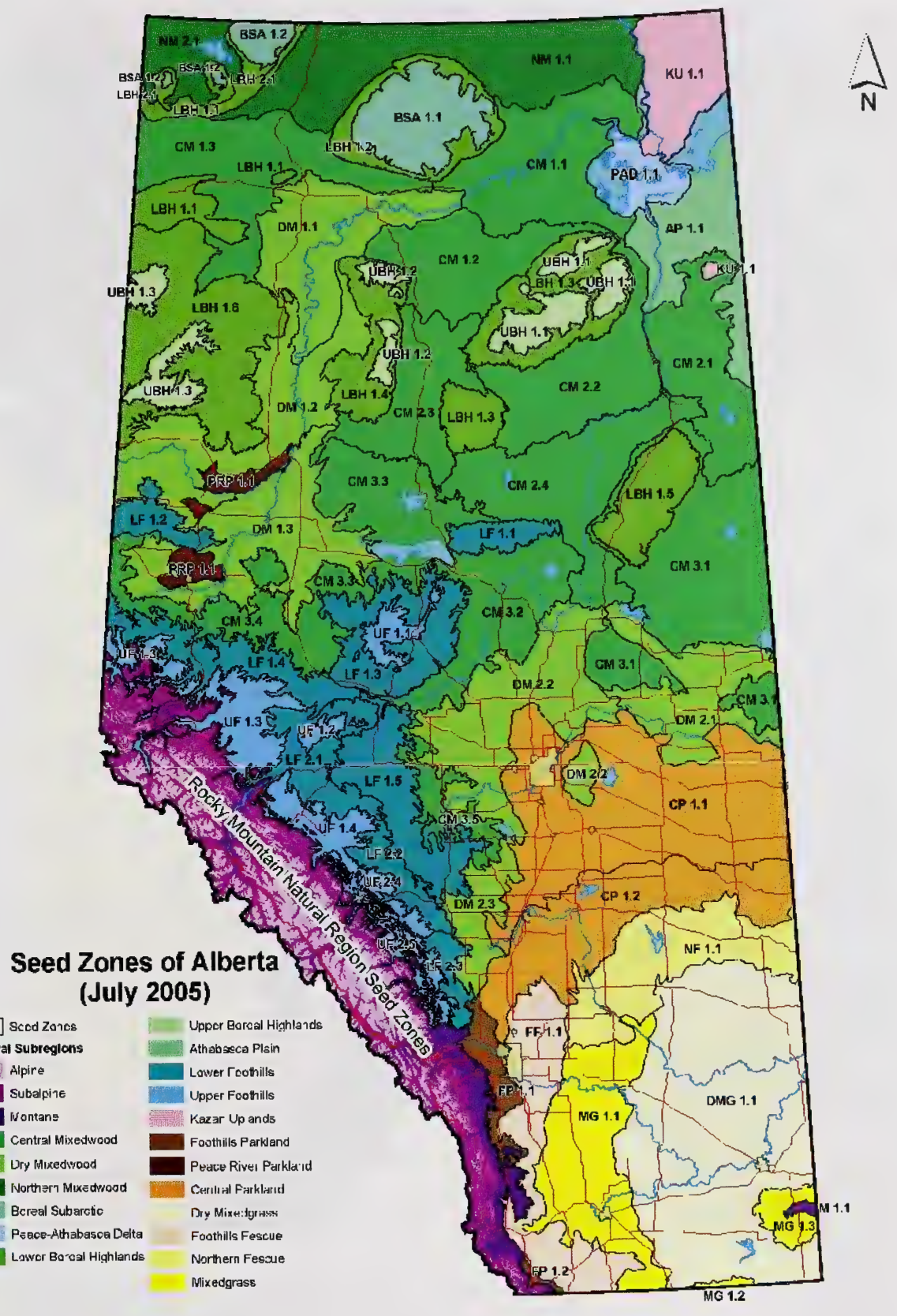




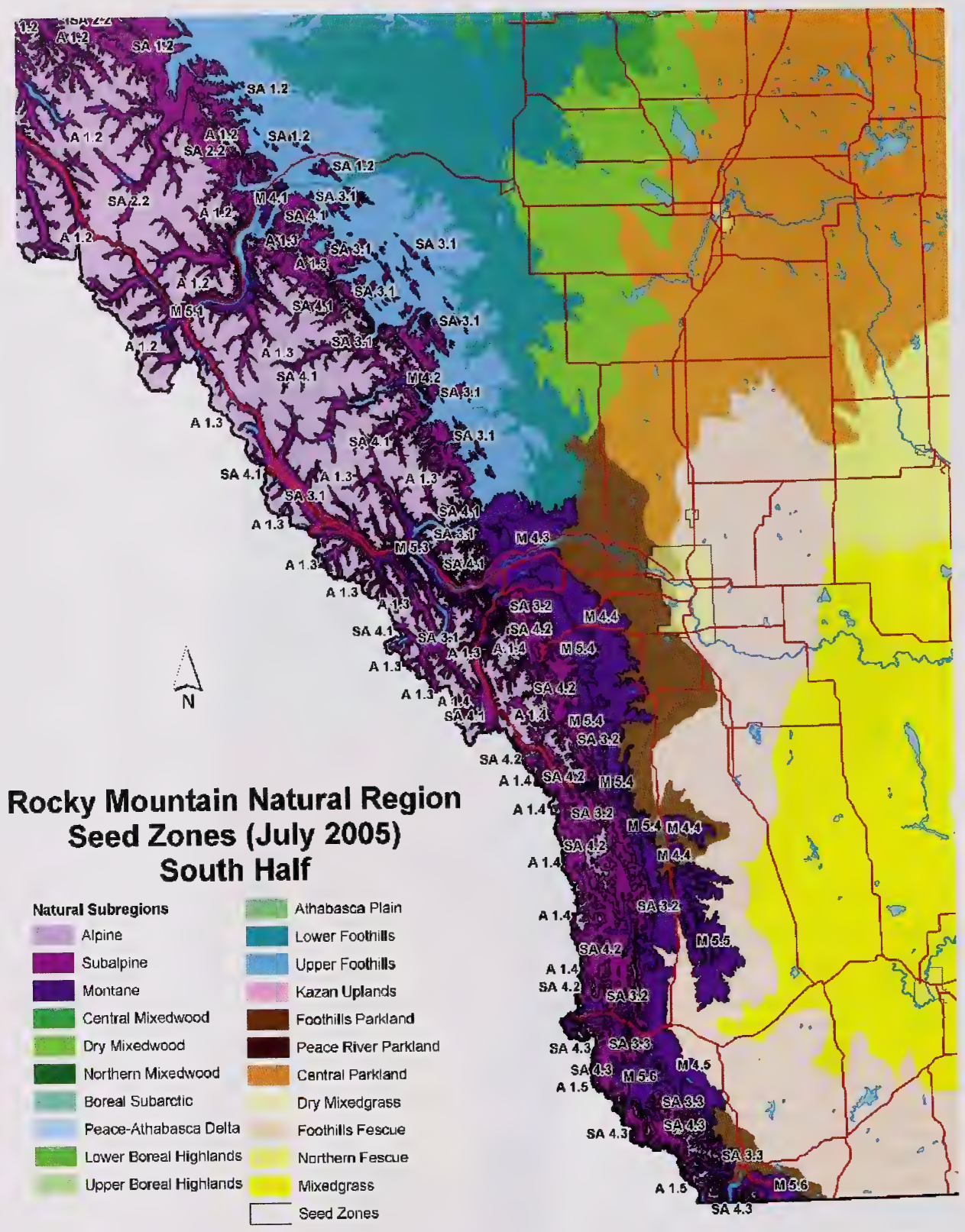




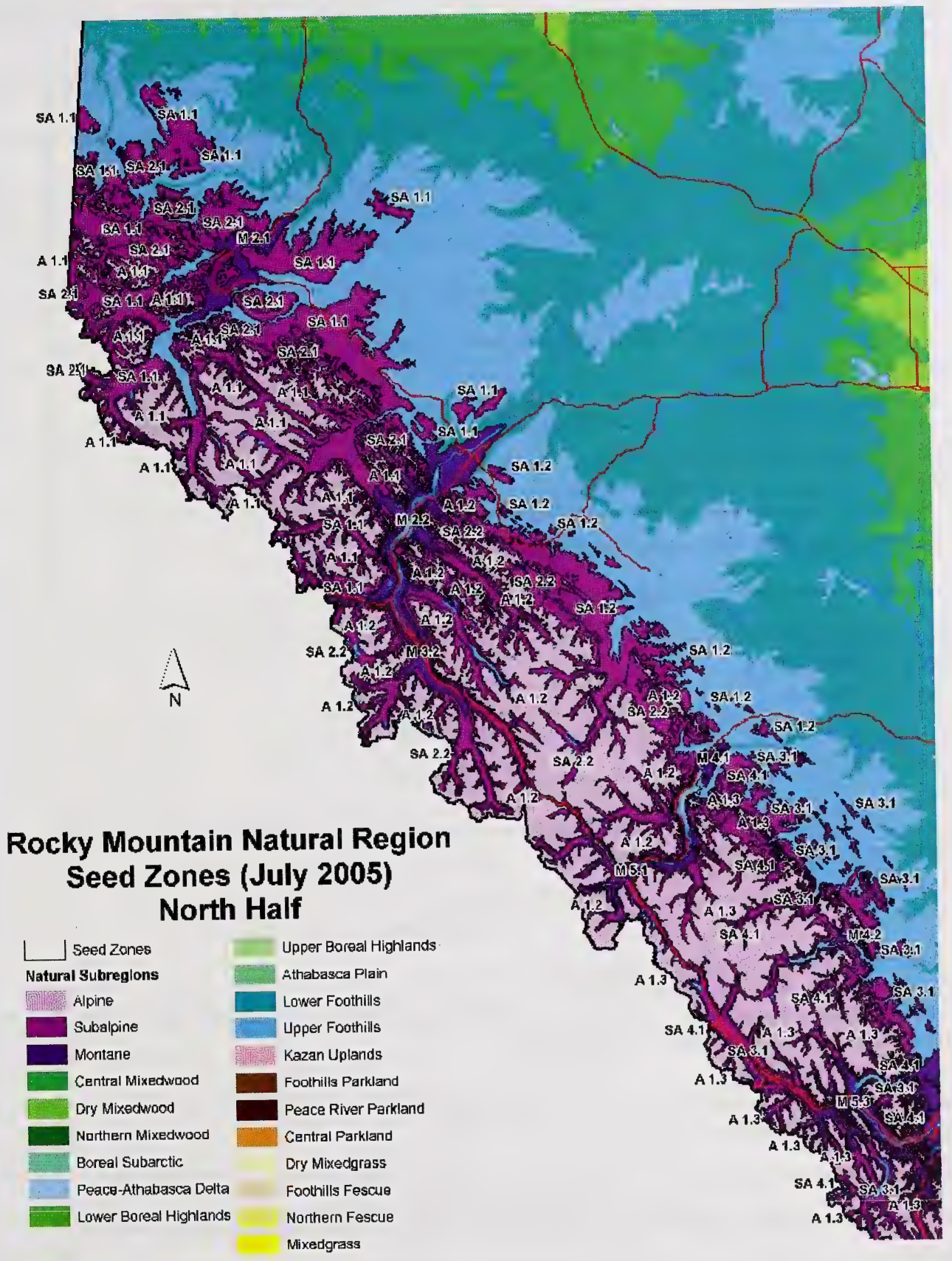


Appendix 8. Request for Deployment Variance for Stream 1 Material

See Standards 10.13, 11.2, 18.2.4, 18.2.5, 18.2.6.

\section{Stream 1 Request for Deployment Variance}

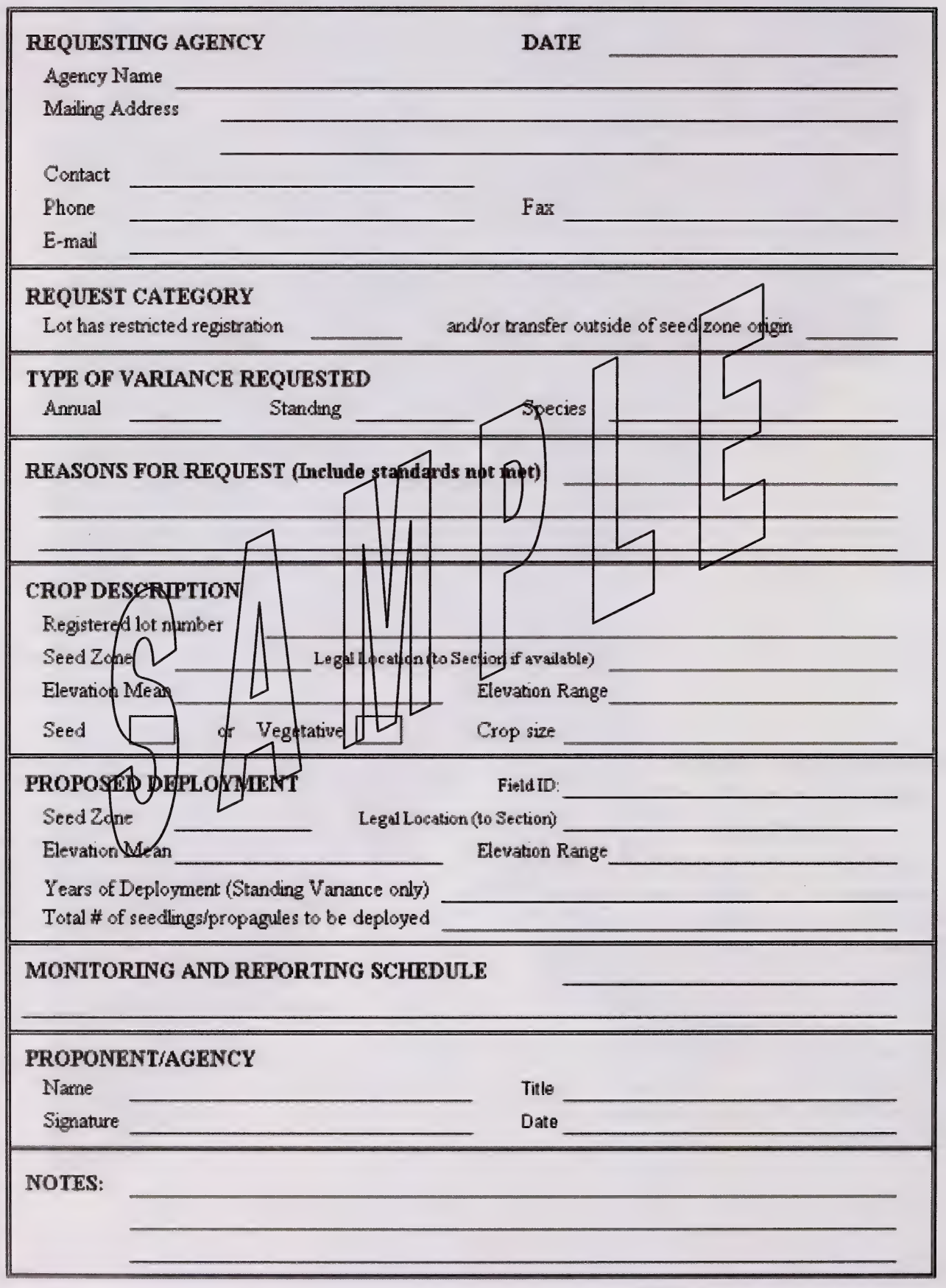




\section{Appendix 9. Assessment of Risk for Stream 2 and Restricted Registration Material}

\section{See Standards 10.13, 18.4.1, 18.4.7, 22.2, 24.4.1.}

\section{Template for Assessment of Restricted Registration Materials}

This template is a generic form to be applied to all materials with restricted registration. It is to be applied at the stand and landscape levels as well as for plantings where seedlings or vegetative material are deployed as mixes or where materials are proposed for deployment as single clones or single-family blocks.

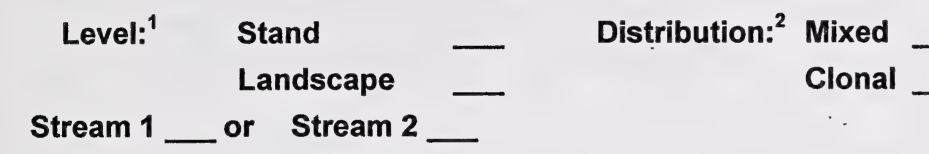

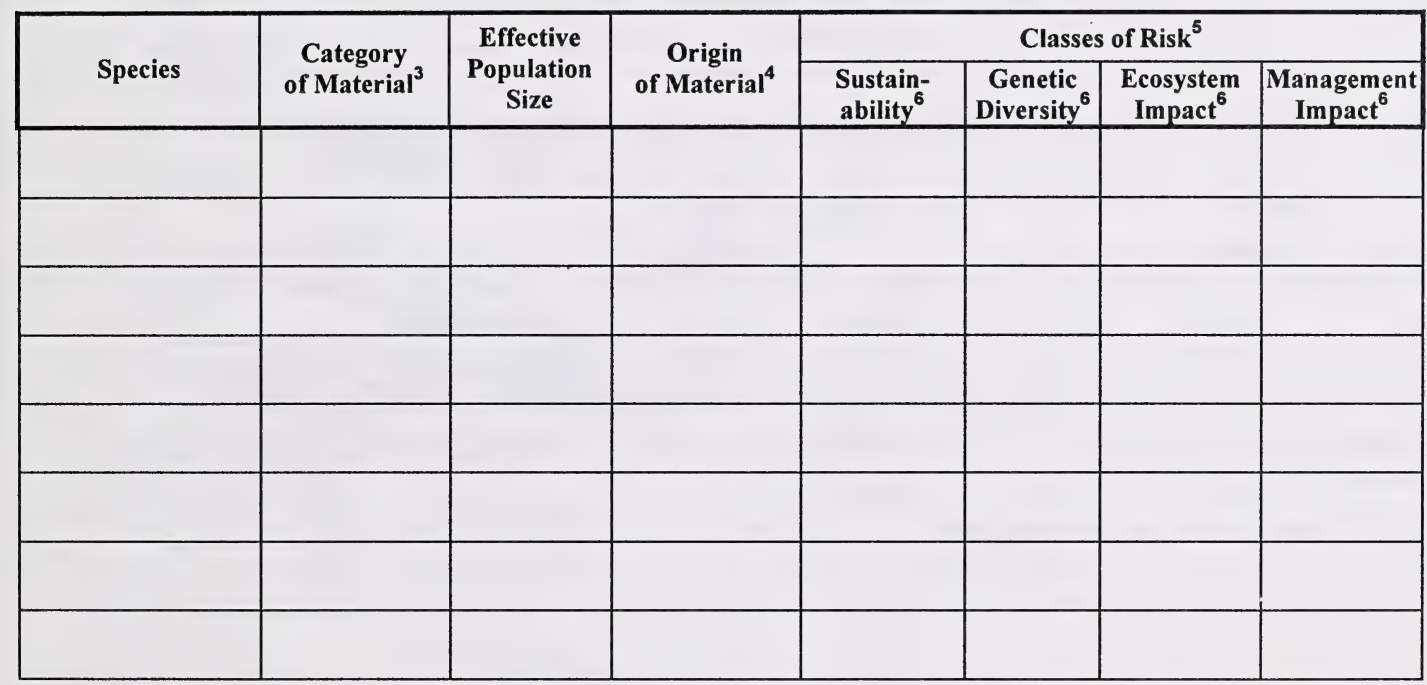

1 "Level" is the size of area for which risks are to be considered; "Stand" refers to an isolated cutblock of average size; "Landscape" refers to the aggregate effect of stands over an area of 10,000 ha, more or less.

2 "Distribution" is the degree of mixing of different genotypes. "Mixed" refers to thorough mixtures of planting stock; "Family/Clonal Blocks" refers to planting of one family or clone.

3 "Category of material" is seed or vegetative material.

4 "Origin of material": locally adapted, hybrid, non-local or GMO.

5 "Classes of risk" represent groupings of several types of risk.

"Sustainability" refers to risks to sustained productivity from inbreeding associated with reduced numbers of parents and to reduced seeding potential when dioecious species are deployed in clonal blocks.

"Genetic diversity" represents potential impacts of reduced genetic diversity, including increased genetic vulnerability to pests and weather effects, genetic recombination in hybrids and reduced evolutionary potential.

"Ecosystem impact" includes potential of improved plantings to serve as centres for pest dispersal, weediness, gene flow and impacts on nontarget species.

"Management impact" includes patterns of distribution of material (scattered or clustered), location (in relation to mills or tree improvement facilities) and expected intensity of silviculture associated with deployment.

${ }^{6}$ For relevant combinations of species, category of material, minimum effective population and origin of material, perceived risk is scored as "Very Low (VL)", "Low (L)", "Medium (M)", "High (H)" or "Very High (VH)" for each of the four classes of risk. Where scores are greater than "Low," the specific risks and proposals for their management are required in the DFMP. 
When required, appropriate tables are to be developed jointly by the proponent and the Department. Following the assessment, the proponent is to include in its DFMP management strategies for Risk Classes scored as greater than "Low." Tables for two scenarios have been developed as shown below.

\section{Assessment of Risk for Stand Level, Mixed Distribution Stream 2 Materials}

\begin{tabular}{|c|c|c|c|c|c|c|c|}
\hline Level ${ }^{7}:$ & $\begin{array}{l}\text { Stand } \\
\text { Landscape }\end{array}$ & $\mathrm{X}$ & Distribution ${ }^{8}:$ & $\begin{array}{l}\text { Mixed } \\
\text { Clonal }\end{array}$ & $\underline{x}$ & & \\
\hline \multirow{2}{*}{ Species } & \multirow{2}{*}{$\begin{array}{c}\text { Category } \\
\text { of Material" }\end{array}$} & \multirow{2}{*}{$\begin{array}{l}\text { Effective } \\
\text { Population } \\
\text { Size }\end{array}$} & \multirow{2}{*}{$\begin{array}{c}\text { Origin } \\
\text { of } \text { Material }^{10}\end{array}$} & \multicolumn{4}{|c|}{ Classes of Risk ${ }^{11}$} \\
\hline & & & & $\begin{array}{l}\text { Sustain- } \\
\text { Ability }^{12}\end{array}$ & $\begin{array}{c}\text { Genetic } \\
\text { Diversity }\end{array}$ & $\begin{array}{l}\text { Ecosystem } \\
\text { Impact }^{12}\end{array}$ & $\begin{array}{c}\text { Management } \\
\text { Impact }^{12}\end{array}$ \\
\hline \multirow{3}{*}{$\begin{array}{l}\text { White spruce, black } \\
\text { spruce, lodgepole } \\
\text { pine, jack pine and } \\
\text { Douglas-fir }\end{array}$} & Seed & $>18$ & Locally Adapted & N/A & N/A & N/A & N/A \\
\hline & Seed & 12 to 18 & Locally Adapted & VL+ & VL+ & VL & VL+ \\
\hline & Seed & 6 to 12 & Locally Adapted & $\mathrm{L}+$ & M & VL+ & $\mathrm{L}+$ \\
\hline
\end{tabular}

\section{Assessment of Risk for Landscape Level, Mixed Distribution Stream 2 Materials}

\begin{tabular}{|c|c|c|c|c|c|c|c|}
\hline Level:"7 & $\begin{array}{l}\text { Stand } \\
\text { Landscape }\end{array}$ & $\underline{x}$ & Distribution: $^{8}$ & $\begin{array}{l}\text { Mixed } \\
\text { Clonal }\end{array}$ & $\underline{x}$ & & \\
\hline \multirow{2}{*}{ Species } & \multirow{2}{*}{$\begin{array}{c}\text { Category } \\
\text { of Material }\end{array}$} & \multirow{2}{*}{$\begin{array}{c}\text { Effective } \\
\text { Population } \\
\text { Size }\end{array}$} & \multirow{2}{*}{$\begin{array}{c}\text { Origin } \\
\text { of }_{\text {Material }}{ }^{10}\end{array}$} & \multicolumn{4}{|c|}{ Classes of Risk ${ }^{11}$} \\
\hline & & & & $\begin{array}{l}\text { Sustain- } \\
\text { Ability }^{12} \\
\end{array}$ & $\begin{array}{c}\text { Genetic } \\
\text { Diversity }\end{array}$ & $\begin{array}{c}\text { Ecosystem } \\
\text { Impact }^{12}\end{array}$ & $\begin{array}{c}\begin{array}{c}\text { Management } \\
\text { Impact }^{12}\end{array} \\
\end{array}$ \\
\hline \multirow{3}{*}{$\begin{array}{l}\text { White spruce, black } \\
\text { spruce, lodgepole } \\
\text { pine, jack pine and } \\
\text { Douglas-fir }\end{array}$} & Seed & $>18$ & Locally Adapted & N/A & N/A & N/A & N/A \\
\hline & Seed & 12 to 18 & Locally Adapted & $\mathrm{L}$ & $\mathrm{L}+$ & $\mathrm{L}$ & $\mathrm{L}+$ \\
\hline & Seed & 6 to 12 & Locally Adapted & M & M+ & M & M \\
\hline
\end{tabular}

7 "Level" is the size of area for which risks are to be considered; "Stand" refers to an isolated cutblock of average size; "Landscape" refers to the aggregate effect of stands over an area of 10,000 ha, more or less.

8 "Distribution" is the degree of mixing of different genotypes. "Mixed" refers to thorough mixtures of planting stock; "Family/Clonal

Blocks" refers to planting of one family or clone.

9 "Category of material" is seed or vegetative material.

10 "Origin of material": locally adapted, hybrid, non-local or GMO.

11 "Classes of risk" represent groupings of several types of risk.

"Sustainability" refers to risks to sustained productivity from inbreeding associated with reduced numbers of parents and to reduced seeding potential when dioecious species are deployed in clonal blocks.

"Genetic diversity" represents potential impacts of reduced genetic diversity, including increased genetic vulnerability to pests and weather effects, genetic recombination in hybrids and reduced evolutionary potential.

"Ecosystem impact" includes potential of improved plantings to serve as centres for pest dispersal, weediness, gene flow and impacts on nontarget species.

"Management impact" includes patterns of distribution of material (scattered or clustered), location (in relation to mills or tree improvement facilities) and expected intensity of silviculture associated with deployment.

${ }^{12}$ For relevant combinations of species, category of material, minimum effective population and origin of material, perceived risk is scored as "Very Low (VL)", "Low (L)", "Medium (M)", "High (H)" or "Very High (VH)" for each of the four classes of risk. Where scores are greater than "Low," the specific risks and proposals for their management are required in the DFMP. 
See Standard 11.1.3.

\section{Appendix 10. Temporary Field Authorization Form}

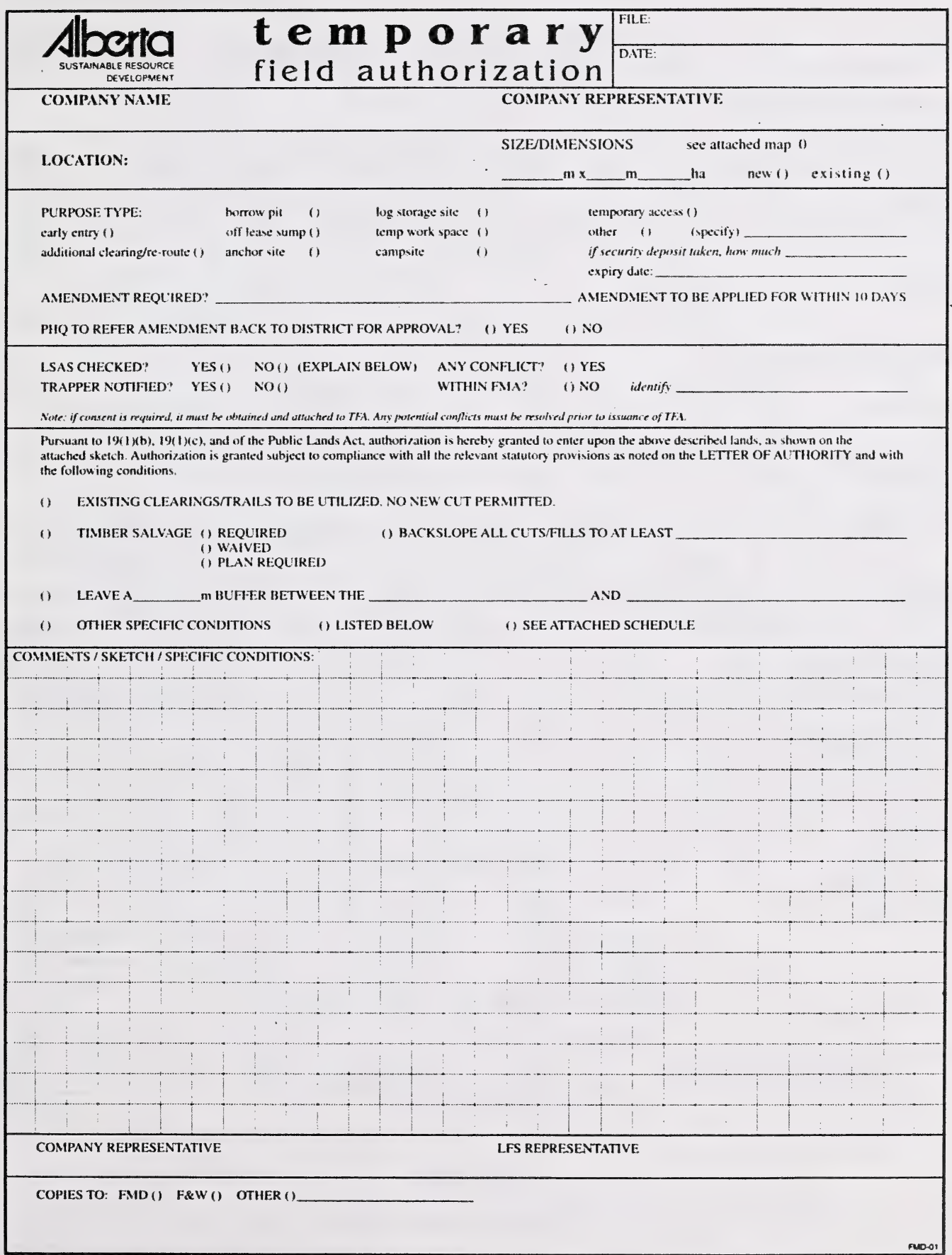




\section{Appendix 11. Parent Tree Selection Form - Wild Stands and Plantations}

See Standards 11.1.5, 25.5, 26.1.

Species

Selection Agency

Field Number

\section{STAND INFORMATION}

Collection Site

Legal Location

Latitude

Longitude

Elevation
Unique Identifier

Selection Date

Stand Comments:

\section{TREE INFORMATION}

Sex Male

Wood Sample YES

Scions YES

Open Pollinated Seed YES

Root Sections YES

$\begin{array}{lll}\square & \text { Female } \\ \square & \text { No } & \square \\ \square & \text { No } & \square \\ \square & \text { No } & \square \\ \square & \text { No } & \square\end{array}$

Monoecious
Collection Date_
Collection Date_
Collection Date_
Collection Date_

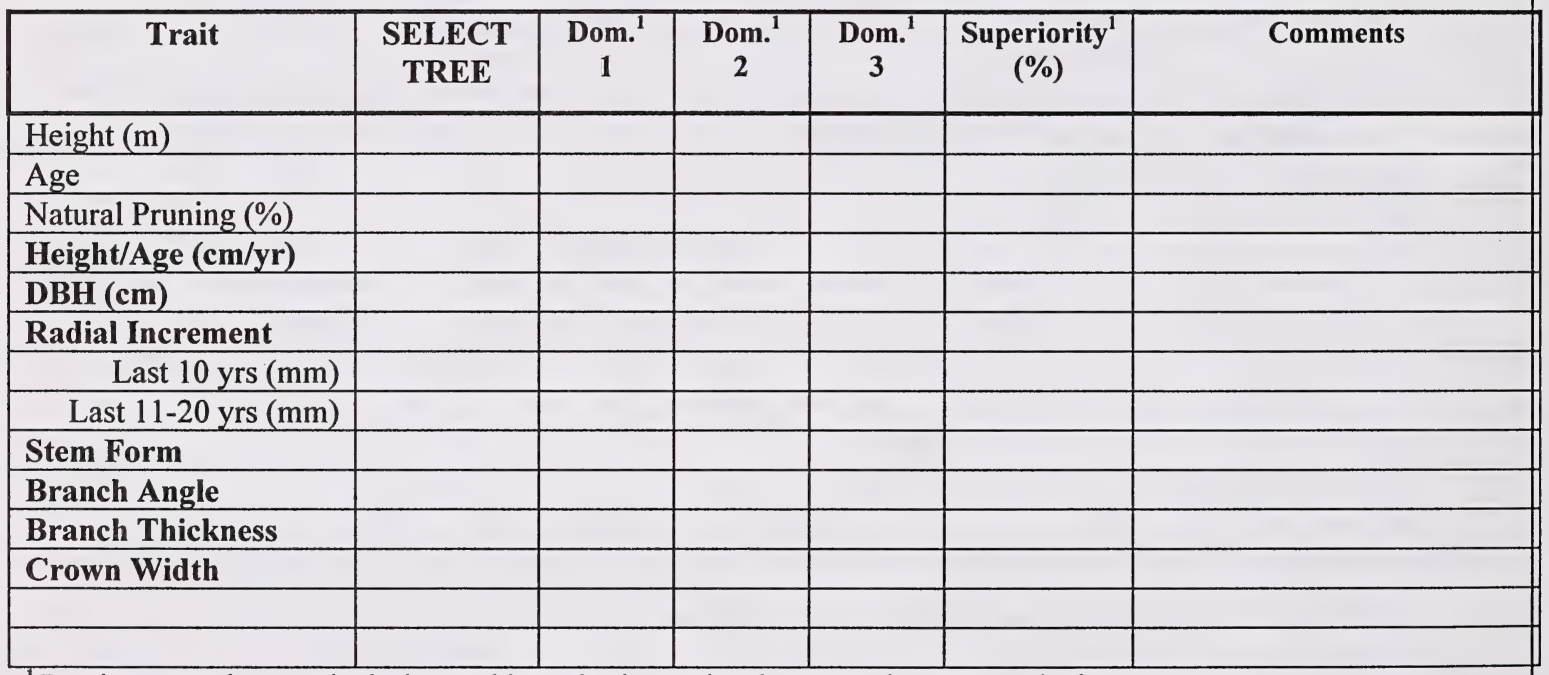

${ }^{1}$ Dominant tree data required when making selections using the comparison tree method

Natural Subregion

Seed Zone

Site Type

Stand Type

Moisture Regime

TREE REMARKS

\begin{tabular}{|l|l|}
\hline Parent Tree Location Map & \multicolumn{1}{|c|}{ Description } \\
\hline & Location/Access \\
& Tree Marking: \\
& Photo Attached YES $\square \quad$ NO $\square$ \\
\hline AGENCY REPRESENTATIVE & Signature $\quad$ Date _ _ \\
\hline
\end{tabular}




\section{Appendix 12. Parent Tree Selection Form - Genetic Tests}

See Standards 11.1.5, 25.5, 26.1.

Species

Collector

Site ID

Site Name

Elevation (m)

Legal Location

SELECTED TREE LOCATION

Selected Tree Field Number \#

Rep.\#

Row \#

SELECTION INFORMATION

Sex Male $\square \quad$ Female

Selection Criteria or Report

Purpose of Selection

Age at Measurement

\begin{tabular}{|l|l|l|}
\hline \multicolumn{1}{|c|}{ Traits } & Data & \\
\hline Height $(\mathrm{m})$ & & \\
\hline DBH $(\mathrm{cm})$ & & \\
\hline (other measured traits below) & & \\
\hline & & \\
\hline & & \\
\hline & & \\
\hline & & \\
\hline Pest Damage & & \\
\hline
\end{tabular}

Breeding Date

Mother

Unique Identifier/

Genetic Identity

Breeding Region

Seed Zone

Deployment Zone

Origin

Latitude

Longitude

Elevation

INFORMATION ON PARENTS OF THIS SELECTION

\section{Unique Identifier \\ Selection Date \\ Collection Agency}

Trial.Code

Latitude

Longitude

UTM Northing

UTM Easting

\section{Set or Block \# \\ Position \# \\ Seedlot \#}




\section{Appendix 13. Decision Tree for Transfer of Stream 1 Material Outside Seed Zone of Origin}

See Standards 11.2, 18.2.2, 18.2.4.

VARIANCE REQUIRED

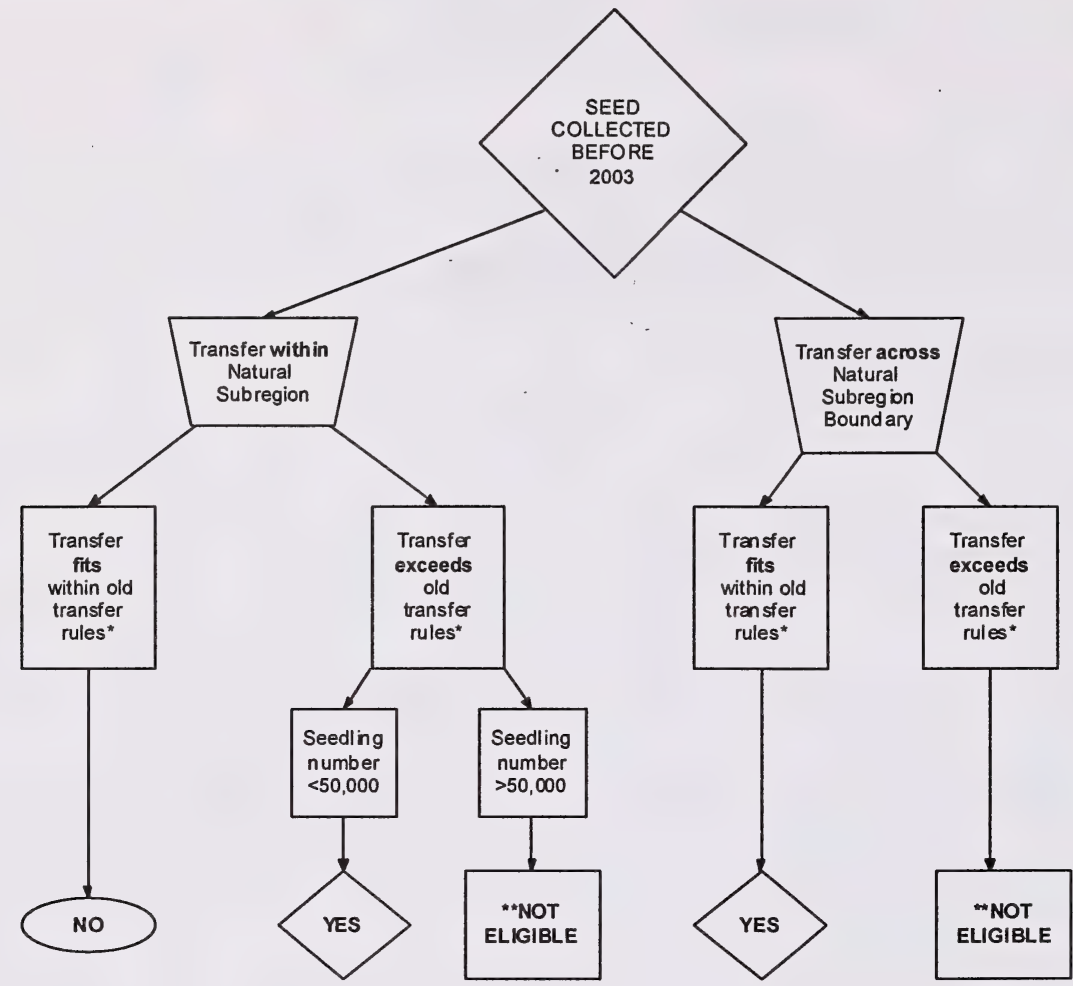

VARIANCE

REQUIRED

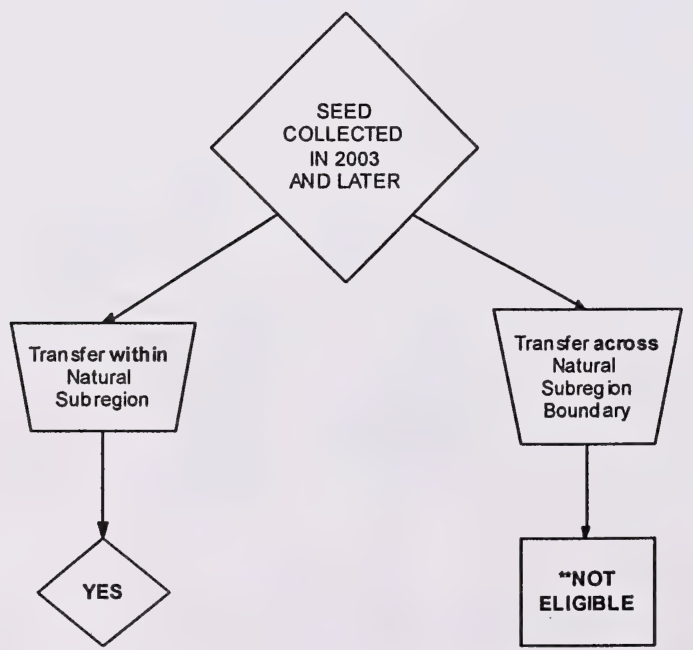

* "Old transfer rules" refers to deployment within 50 miles and within 500 feet elevation from the collection location.

** Transfers classified as "not eligible" for a variance request may be considered in emergencies. 


\section{Appendix 14. Stream 1 Seedling and Vegetative Propagule Lot Deployment Limit by Seed Zone}

See Standards 11.3, 18.2.3, 18.2.4.

\begin{tabular}{|c|c|c|c|c|c|c|c|c|}
\hline \multirow[t]{2}{*}{$\begin{array}{c}\text { Size } \\
\text { Category }\end{array}$} & \multirow[t]{2}{*}{$\begin{array}{l}\text { Seed Zone } \\
\text { Area (ha) }\end{array}$} & \multicolumn{2}{|c|}{$\begin{array}{l}\text { Maximum Number } \\
\text { Deployable per } \text { Lot }^{2}\end{array}$} & \multicolumn{3}{|c|}{$\begin{array}{c}\text { Approximate kg } \\
\text { Seed }^{3}\end{array}$} & \multicolumn{2}{|c|}{$\begin{array}{c}\text { Approximate } \\
\text { Coverage in ha } \\
\text { (@1800/ha) }\end{array}$} \\
\hline & & Seedlings & $\begin{array}{l}\text { Vegetative } \\
\text { Propagules } \\
\end{array}$ & Sw & Aw & Pl & Seedlings & $\begin{array}{c}\text { Vegetative } \\
\text { Propagules } \\
\end{array}$ \\
\hline 1 & $>1$ million & 25 million & 20 million & 150 & 6.1 & 250 & 13,888 & 11,110 \\
\hline 2 & $\begin{array}{l}500,000 \text { to } \\
1 \text { million }\end{array}$ & 20 million & 16 million & 120 & 4.9 & 200 & 11,111 & 8,889 \\
\hline 3 & $\begin{array}{l}100,000 \text { to } \\
500,000\end{array}$ & 15 million & 12 million & 90 & 3.7 & 150 & 8,333 & 4,167 \\
\hline 4 & $<100,000$ & 10 million & 8 million & 60 & 2.4 & 100 & 5,555 & 2,778 \\
\hline
\end{tabular}

${ }^{1}$ Refer to Appendix 7 for seed zone sizes.

${ }^{2}$ Deployment limit includes seed and vegetative propagules from a single lot.

${ }^{3}$ Assumes two seeds per cavity. 


\section{Appendix 15. Documentation Form for Non-Local Material}

See Standards 11.5, 25.5, 26.1.

To be used for documenting genetic materials intended for use in controlled parentage programs where materials did not originate from Alberta public land.

Company/Agency in Possession

Submitted by

Unique Identifier

\section{COLLECTION INFORMATION}

Origin Place Name

Latitude

Longitude

UTM Northing

UTM Easting

Legal Location

Elevation

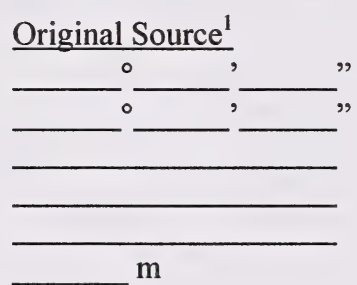

Plantation Collection Site ${ }^{2}$

Comments

${ }^{1}$ Original location of initial wild collection to be documented where known

${ }^{2}$ Plantation location where material is collected from a non-wild source

\section{GENETIC INFORMATION}

\section{Species}

Male Parent Information

Female Parent Information

Comments

\section{PHYSICAL INFORMATION}

\section{Type of Material}

Quantity of Material

Comments

Note: Bold type indicates required information. 


\section{Appendix 16. Transportation or Storage of Research or CPP Parent Material Form}

\section{See Standard 12.2.}

To accompany any genetic material (seed, pollen, cuttings, etc.) to be included in a controlled parentage or research program.

Insert one copy inside container, fasten one copy to outside of container and keep third copy for your records.

\section{UNIQUE IDENTIFIER}

$$
\text { (or other identifying information, if selected before January 1,2003) }
$$

\section{DESTINATION FACILITY}

Mailing Address

Contact

Phone

Fax

E-mail

\section{COLLECTING AGENCY}

Representative

Phone

E-mail

DATE OF COLLECTION

DATE OF SHIPPING

\section{MATERIAL DESCRIPTION}

Species

Type of Material

Amount of Material

(cones, fruit, seed, pollen, cuttings, roots)

(specify measurement units: e.g. grams of seed, metres of roots, number or volume of cones) 


\section{Appendix 17. Alberta Reforestation Seed and Vegetative Materials Withdrawal and Transportation Form}

See Standards 12.5.1, 12.5.3.

\section{ALBERTA SUSTAINABLE RESOURCE DEVELOPMENT \\ ALBERTA REFORESTATION SEED \& VEGETATIVE MATERIALS WITHORAWAL AND TRANSPORTATION}

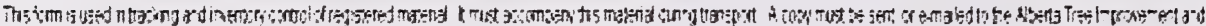

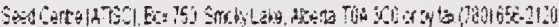

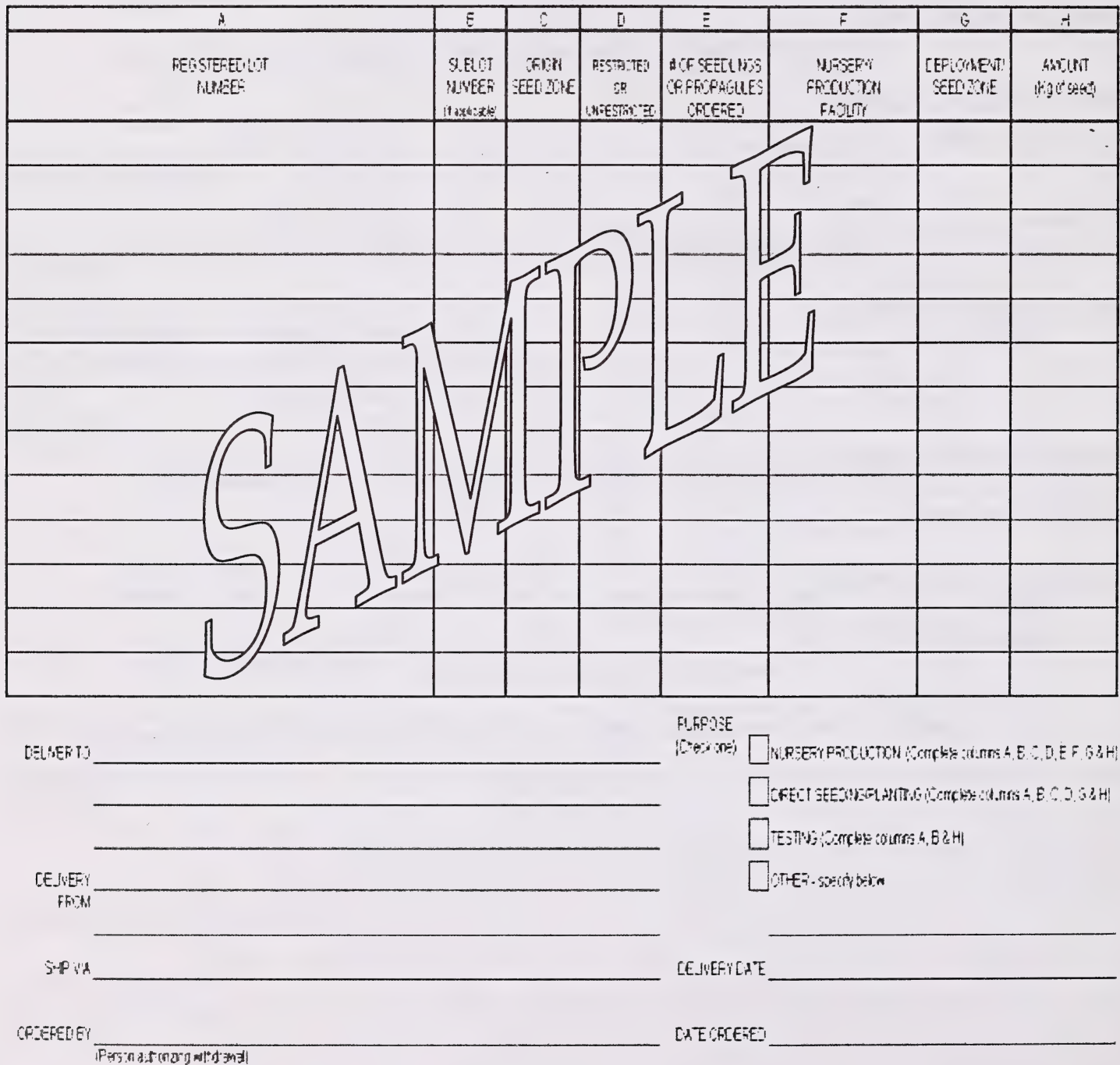




\section{Appendix 18. Controlled Parentage Program Plan - Contents}

See Standards 18.4.2, 24.1, 24.2.

The following topics are to be addressed in a Controlled Parentage Program Plan.

\section{Introduction}

\section{History}

- Early project development

- Cooperative structure

- Present status

\section{Program Objectives}

- Target species

- Ecology

- Genetics

- Needs and goals

- Improvement traits

- Similar programs in other regions

Breeding Region/Deployment Zone Delineation

- Ecological information

- Forest types and plant communities

- Topography

- Parent materials

- Climate

- Genetic information

- Administration and land use information

- Mapping

- Location description (latitude, longitude, elevation, range)

\section{Parent Selection Plan}

- Selection traits

- Selection strategy, including consideration of correlated traits (e.g. wood density and growth)

- Materials collection

\section{Breeding/Clonal Plan}

a) Seed-based programs

- First generation

- Traits

- Base population

- Breeding population

- Schedule and predicted timelines

- Gain estimates

- Advanced generation/pedigree information (where available)

b) Clonal programs

- Base population

- Traits

- Schedule and predicted timelines

- Link to breeding program, if any

- Selection intensity and target $\mathrm{Ne}$ 
- Test objective (e.g. deployment zone delineation, progeny trial)

- Test sites

- Selection criteria

- Number of test sites

- Test site locations and descriptions

- Test site protection

- Test design

- Content and structure (controls, plot structure, blocking, replication)

- Trees per treatment per site

- Trial establishment

- Field marking

- Site maintenance

- Competition and ingress control

- Maintenance of tree identification

- Trial measurement

- Variables

- Measurement schedule

- Data management

- Analysis

\section{Production Plan}

a) Seed-based programs

- Orchard design

- Production design and limits (Appendix 21) (standard 24.4)

- Design and layout

- Orchard establishment

- Orchard management

- Pollen contamination

- Pollen management

- Weed, insect, and disease monitoring and control

- Tree management

- Crop management

b) Clonal programs

- $\quad$ Permanent Sample Tree monitoring

- Stoolbed design and limits (Appendix 21), or

- In vitro micro-propagation

- Production design and limits (Appendix 21)

- Design and layout

- Establishment

- Management

- Weed, insect, and disease monitoring and control

\section{Deployment Plan}

\section{Genetic Conservation Plan}

- In situ

- Ex situ

- Considerations upon termination of tests

Link to Supportive Research Plan(s) 
Reference to Additional Relevant Reports

- Genetic Test Establishment Report

- Genetic Test Measurement Report

- Genetic Test Analysis Report

- Parent Tree Selection Report 


\section{Appendix 19. Breeding Regions and Deployment Zones and Associated Programs as of May 1, 2002}

See Standards 18.4.2, 33.6, 34.5.

Controlled parentage program seed movement guidelines and deployment rules differ from natural stand seed movement guidelines because seed or vegetative propagule production is carried out in seed orchards and stoolbeds.

Deployment of seed orchard varieties is controlled by a breeding region/deployment zone system. Each breeding region/deployment zone is based on a target deployment area for a single species. Seed orchards are mostly developed on agriculture land outside the forest zone to reduce outcrossing with contaminating pollen. Repeated collections are made from the same trees and control is exercised on genetic composition, genetic quality and genetic diversity contained in the seedlot collection. Breeding regions are not necessarily coincident with seed zones, as they are based on a target deployment area for a single . specified species and are generally accompanied by provenance and progeny testing.

Breeding regions are initially delineated and mapped on the basis of general genetic and ecological information as well as administrative boundaries, and are reviewed and modified on the basis of further progeny and provenance testing. Deployment zones are delineated on the basis of prior testing for adaptiveness of the proposed genetic material in a proposed deployment zone.

Seed and vegetative propagule movement and deployment from controlled parentage programs and production facilities are unrestricted within their specific breeding region or deployment zone. However, the Department may place conditions on the use of these materials within the breeding region if warranted by scientific considerations. Areas within a breeding region or deployment zone boundary that are suspected to be environmentally atypical are dealt with as exclusion areas.

The breeding region/ deployment zoning system will be periodically updated to accommodate new projects, new scientific information, changes in tree improvement objectives or other biological considerations.

The 20 currently approved conifer breeding regions/deployment zones in Alberta include nine white spruce, three black spruce, five lodgepole pine, one jack pine, one Douglas-fir and one western larch (see below). It is recognized that there are other breeding programs (hardwood and softwood) under development in Alberta.

To obtain larger scale maps, contact the Public Lands and Forests Division of the Department. 
Description of Breeding Regions By Tree Species

\begin{tabular}{|c|c|c|}
\hline Species & $\begin{array}{l}\text { Breeding } \\
\text { Region }\end{array}$ & Description \\
\hline Lodgepole pine (Fig 3) & $\mathrm{B} 1$ & $\begin{array}{l}\text { Northern lower foothills breeding region dominated by } \\
\text { mixedwood forest types. Approved operational elevations } \\
\text { are } 800 \text { to } 1200 \text { metres. }\end{array}$ \\
\hline Lodgepole pine (Fig 3) & B2 & $\begin{array}{l}\text { Northern upper foothills breeding region dominated by conifer forest } \\
\text { types. Approved operational elevations are } \\
1200 \text { to } 1600 \text { metres. }\end{array}$ \\
\hline Lodgepole pine (Fig 3) & $\mathrm{C}$ & $\begin{array}{l}\text { Swan Hills area outlier foothills breeding region dominated by pure } \\
\text { and mixed conifer forest types. Approved operational elevations are } \\
800 \text { to } 1200 \text { metres. Area of lodgepole and jack pine hybridization. }\end{array}$ \\
\hline Lodgepole pine (Fig 3) & $\mathrm{K} 1$ & $\begin{array}{l}\text { Southern upper foothills breeding region dominated by conifer forest } \\
\text { types. Approved operational elevations are } 1100 \text { to } 1500 \text { metres. }\end{array}$ \\
\hline Lodgepole pine (Fig 3) & $\mathbf{J}$ & $\begin{array}{l}\text { Clear Hills area outlier foothills breeding region dominated by } \\
\text { mixedwood and conifer forest types, including areas of lodgepole } \\
\text { and jack pine hybridization. Approved operational elevations are } 600 \\
\text { to } 1000 \text { metres. }\end{array}$ \\
\hline Jack pine (Fig. 3) & $\mathrm{P} 1$ & $\begin{array}{l}\text { Northeastern lowlands boreal breeding region dominated by } \\
\text { mixedwood forest types. Approved operational elevations are } 250 \text { to } \\
600 \text { metres. }\end{array}$ \\
\hline Western larch (Fig. 3) & $\mathbf{M}$ & $\begin{array}{l}\text { Southern lower subalpine breeding region dominated by conifer } \\
\text { forest types. This species is rare in Alberta. The main project } \\
\text { objectives are conservation and restricted use for breeding region } \\
\text { deployment. Approved operational elevations are } 1450 \text { to } 1700 \\
\text { metres. }\end{array}$ \\
\hline White spruce (Fig. 4) & $\mathrm{D}$ & $\begin{array}{l}\text { Swan Hills area outlier lower foothills breeding region dominated by } \\
\text { mixedwood forest types. Approved operational elevations are } 650 \text { to } \\
1050 \text { metres. }\end{array}$ \\
\hline White spruce (Fig. 1) & D1 & $\begin{array}{l}\text { Slave Lake area boreal breeding region dominated by boreal lowland } \\
\text { and upland mixedwood forest types. Approved operational } \\
\text { elevations are } 500 \text { to } 800 \text { metres. }\end{array}$ \\
\hline White spruce (Fig. 1) & $\mathrm{E}$ & $\begin{array}{l}\text { Northeastern boreal lowland breeding region dominated by } \\
\text { mixedwood forest types. Approved operational elevations are } 300 \text { to } \\
650 \text { metres. }\end{array}$ \\
\hline White spruce (Fig. 1) & E1 & $\begin{array}{l}\text { Northeastern boreal lowland breeding region dominated by } \\
\text { mixedwood forest types. Northern extension of Breeding Region E. } \\
\text { Approved operational elevations are } 250 \text { to } 600 \text { metres. }\end{array}$ \\
\hline White spruce (Fig. 1) & E2 & $\begin{array}{l}\text { East central sub-boreal and parkland breeding region dominated by } \\
\text { mixedwood and parkland forest types. } \\
\text { Project objectives include conservation and restricted } \\
\text { Deployment. Approved operational elevations are } 550 \text { to } 750 \text { metres. }\end{array}$ \\
\hline White spruce (Fig. 1) & G1 & $\begin{array}{l}\text { Northern lower foothills breeding region dominated by } \\
\text { mixedwood forest types. Approved operational elevations } \\
\text { are } 650 \text { to } 1050 \text { metres. }\end{array}$ \\
\hline White spruce (Fig. 1) & $\mathrm{G} 2$ & $\begin{array}{l}\text { Northwestern outlier foothills breeding region dominated by } \\
\text { mixedwood forest types. Approved operational elevations are } 500 \text { to } \\
900 \text { metres }\end{array}$ \\
\hline White spruce (Fig. 1) & $\mathrm{H}$ & $\begin{array}{l}\text { Northwestern boreal lowlands breeding region dominated by } \\
\text { mixedwood forest types. Approved operational elevations are } 250 \text { to } \\
550 \text { metres elevation. }\end{array}$ \\
\hline White spruce (Fig. 1) & I & $\begin{array}{l}\text { North-central lower foothills breeding region dominated by } \\
\text { mixedwood forest types. Approved operational elevations are } 800 \text { to } \\
1200 \text { in the south and } 700 \text { to } 1050 \text { metres in the north. }\end{array}$ \\
\hline
\end{tabular}


Description of Breeding Regions By Tree Species (cont'd)

\begin{tabular}{|l|l|l|}
\hline Species & $\begin{array}{l}\text { Breeding } \\
\text { Region }\end{array}$ & Description \\
\hline Interior Douglas-fir (Fig. 4) & F1 & $\begin{array}{l}\text { Southern montane breeding region dominated by montane } \\
\text { mixedwood forest types. Approved operational elevations are 1300 } \\
\text { to 1550 metres (up to 1700 m in the Porcupine Hills). }\end{array}$ \\
\hline Black spruce (Fig. 2) & L1 & $\begin{array}{l}\text { North-central lower foothills breeding region dominated by } \\
\text { mixedwood forest types. Approved operational elevations are } 800 \text { to } \\
1200 \text { metres. }\end{array}$ \\
\hline Black spruce (Fig. 2) & L2 & $\begin{array}{l}\text { Northern lower foothills breeding region dominated by } \\
\text { mixedwood forest types. Approved operational elevations are } 800 \text { to } \\
1200 \text { metres. }\end{array}$ \\
\hline Black spruce (Fig. 2) & L3 & $\begin{array}{l}\text { Northeastern boreal lowlands breeding region dominated by } \\
\text { mixedwood forest types. Approved operational elevations are } 300 \text { to } \\
650 \text { metres. }\end{array}$ \\
\hline
\end{tabular}


Figure 1. White Spruce Breeding Regions In Alberta

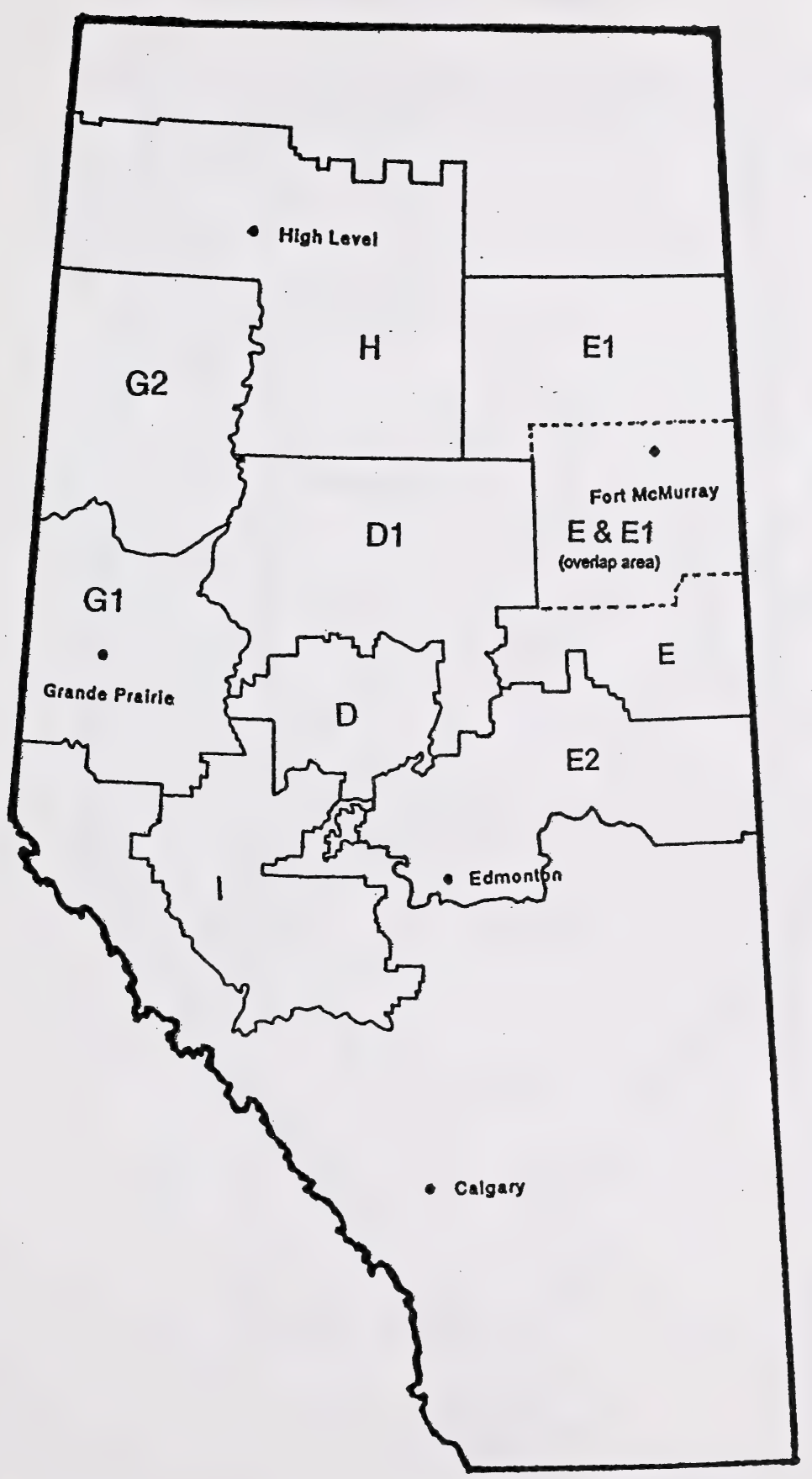


Figure 2. Black Spruce Breeding Regions In Alberta

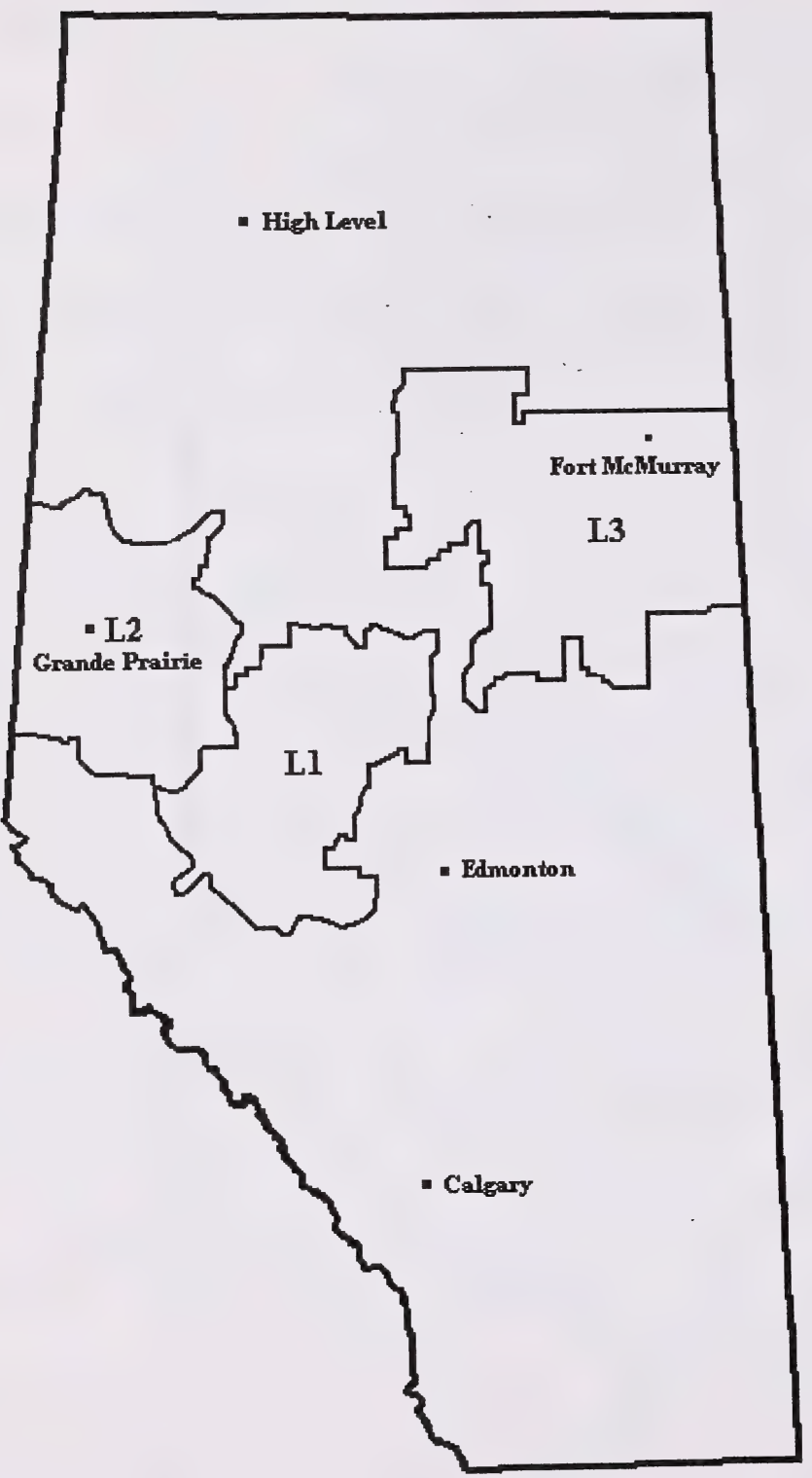


Figure 3. Lodgepole Pine, Jack Pine and Western Larch Breeding Regions in Alberta

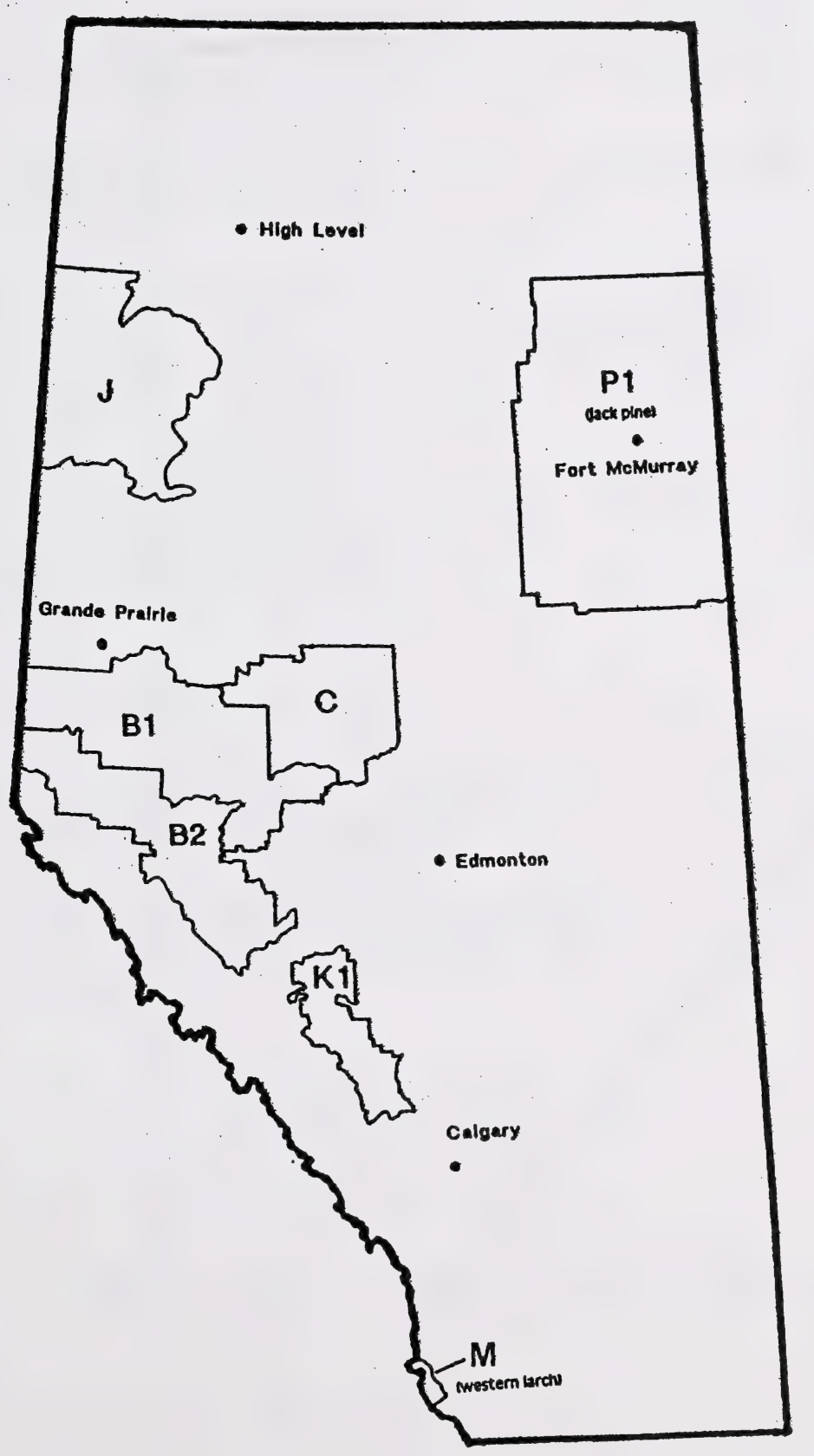


Figure 4. Douglas-fir Breeding Region in Alberta

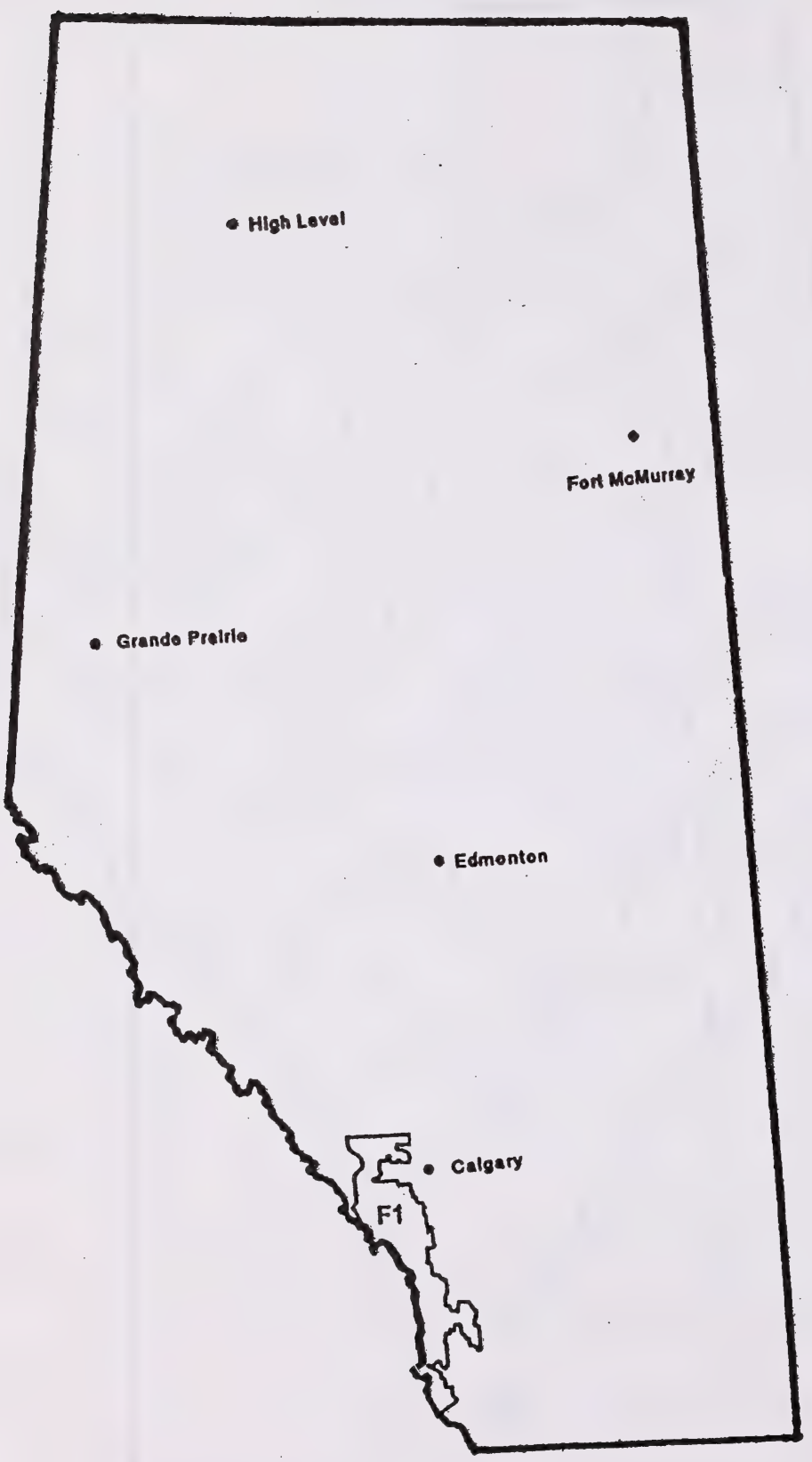




\section{Appendix 20. Cumulative Ne Across Production Facilities and/or Production Years}

See Standards 18.4.3, 18.4.4, 32.6, 33.4.3, 33.4.4, 34.3.3.

Cumulative effective population size, or cumulative $\mathrm{Ne}$, is the effective population size $(\mathrm{Ne})$ of the output of a production facility or facilities, or of material deployed from that facility or facilities, calculated over years and/or across production facilities, for a given breeding region or deployment zone.

\section{STEPS IN CALCULATING CUMULATIVE Ne}

See below for a worked example, including three populations with subsets of 60 unrelated and non-inbred genotypes. Columns in Table 2 are referenced in steps.

1. For each population to be included in the cumulative assessment, calculate $\mathrm{p}_{\mathrm{ij}}$, the proportional contribution to population $\mathrm{i}$ by genotype $\mathrm{j}$ (example: $\mathrm{p}_{1 \mathrm{j}} \mathrm{p}_{2 \mathrm{j}}$ and $\mathrm{p}_{3 \mathrm{j}}$ are listed in columns 2,4 and 6 for populations 1, 2 and 3 respectively). See Appendix 36 for $p_{i}$ estimation procedures.

2. Multiply the proportional contribution by the total number of plants deployed from that population (example: Table 1) to obtain $n_{i j}$ (example: $n_{1 j} n_{2 j}$ and $n_{3 j}$ are shown in columns 8,9 and 10 for populations 1,2 and 3 respectively).

3. Sum each genotype's contribution ntot ${ }_{\mathrm{j}}$ across populations (column 11).

4. Express that number as a proportion of the total number of plants deployed (divide ntot $t_{i}$ by the sum of column 11 entries to give $\mathrm{pc}_{\mathrm{j}}$ values in column 12).

5. For an orchard containing unrelated and non-inbred genotypes, square $\mathrm{pc}_{\mathrm{j}}$ values and sum over genotypes $\left(\Sigma \mathrm{pc}_{\mathrm{j}}^{2}\right.$; table row 61 , column 13$)$.

And finally:

6. Cumulative $\mathrm{Ne}=1 / \Sigma \mathrm{pc}_{\mathrm{j}}^{2}$ (table row 62 , column 13 ).

Note: For an orchard containing related and/or inbred genotypes, cumulative Ne would be calculated as outlined in Appendix 36, using $\mathrm{pc}_{\mathrm{j}}$ values (e.g. column 12, rows 1-60) as the $\mathbf{p}$ vector, and generating the covariance matrix C (defined in Appendix 36); then cumulative $\mathrm{Ne}=0.5 / \mathbf{p}^{\prime} \mathbf{C p}$.

Note that $\mathrm{Ne}$ values for each individual population are shown in columns 3, 5 and 7, row 62; the cumulative $\mathrm{Ne}$ in this example is less than the largest and greater than the smallest individual population Ne. Cumulative $\mathrm{Ne}$ will always be greater than the smallest $\mathrm{Ne}$ of individual populations, and may be larger or smaller than the largest.

\section{EXAMPLE}

Three years' production from a seed orchard is considered here. One bulk seedlot is collected in each of the three years. Sixty clones are included in the orchard initially; the orchard is successively rogued to 40 and then to 20 genotypes for years 2 and 3 respectively. Genotypes are non-inbred and unrelated.

Table 1. Numbers deployed from each of the three seedlots

\begin{tabular}{|c|c|c|c|c|}
\hline Seedlot & Seedlot 1 & Seedlot 2 & Seedlot 3 & Total \\
\hline \# deployed & 600,000 & 850,000 & 200,000 & $1,650,000$ \\
\hline
\end{tabular}


Table 2. Genotypic contributions and calculated Ne values

\begin{tabular}{|c|c|c|c|c|c|c|c|c|c|c|c|c|c|}
\hline & $\begin{array}{c}\text { Column } \\
1\end{array}$ & 2 & 3 & 4 & 5 & 6 & 7 & 8 & 9 & 10 & 11 & 12 & 13 \\
\hline $\begin{array}{l}\text { Table } \\
\text { row }\end{array}$ & $\begin{array}{c}\text { Geno- } \\
\text { type }\end{array}$ & $\mathbf{p}_{\mathbf{i j}}$ & $p_{1 j}{ }^{2}$ & $\mathbf{p}_{2 j}$ & $\mathbf{p}_{2 \mathrm{j}}{ }^{2}$ & $\mathbf{p}_{3 \mathbf{j}}$ & $\mathrm{p}_{3 \mathrm{j}}{ }^{2}$ & $n_{1 j}$ & $\mathbf{n}_{\mathbf{2 j}}$ & $\mathbf{n}_{3 \mathbf{j}}$ & ntot $_{\mathrm{j}}$ & $p c_{j}$ & $\mathrm{pc}_{\mathrm{j}}^{2}$ \\
\hline 1 & 1 & 0.032 & 0.00102 & 0.098 & 0.00960 & 0.057 & 0.00325 & 19200 & 83300 & 11400 & 113900 & 0.069 & 0.00477 \\
\hline 2 & 2 & 0.031 & 0.00096 & 0.035 & 0.00123 & 0.054 & 0.00292 & 18600 & 29750 & 10800 & 59150 & 0.036 & 0.00129 \\
\hline 3 & 3 & 0.029 & 0.00084 & 0.015 & 0.00023 & 0.043 & 0.00185 & 17400 & 12750 & 8600 & 38750 & 0.023 & 0.00055 \\
\hline 4 & 4 & 0.016 & 0.00026 & 0.042 & 0.00176 & 0.041 & 0.00168 & 9600 & 35700 & 8200 & 53500 & 0.032 & 0.00105 \\
\hline 5 & 5 & 0.012 & 0.00014 & 0.023 & 0.00053 & 0.060 & 0.00360 & 7200 & 19550 & 12000 & 38750 & 0.023 & 0.00055 \\
\hline 6 & 6 & 0.020 & 0.00040 & 0.022 & 0.00048 & 0.058 & 0.00336 & 12000 & 18700 & 11600 & 42300 & 0.026 & 0.00066 \\
\hline 7 & 7 & 0.022 & 0.00048 & 0.006 & 0.00004 & 0.056 & $\mid 0.00314$ & 13200 & 5100 & 11200 & 29500 & 0.018 & 0.00032 \\
\hline 8 & 8 & 0.027 & 0.00073 & 0.047 & 0.00221 & 0.053 & $\mid 0.00281$ & 16200 & 39950 & 10600 & 66750 & 0.040 & 0.00164 \\
\hline 9 & 9 & 0.006 & 0.00004 & 0.031 & 0.00096 & 0.037 & $\mid 0.00137$ & 3600 & 26350 & 7400 & 37350 & 0.023 & 0.00051 \\
\hline 10 & 10 & 0.005 & 0.00003 & 0.004 & 0.00002 & 0.049 & 0.00240 & 3000 & 3400 & 9800 & 16200 & 0.010 & 0.00010 \\
\hline 11 & 11 & 0.025 & 0.00063 & 0.016 & 0.00026 & 0.065 & 0.00423 & 15000 & 13600 & 13000 & 41600 & 0.025 & \begin{tabular}{|l|l|}
0.00064 \\
\end{tabular} \\
\hline 12 & 12 & 0.001 & 0.00000 & 0.030 & 0.00090 & 0.044 & 0.00194 & 600 & 25500 & 8800 & 34900 & 0.021 & 0.00045 \\
\hline 13 & 13 & 0.008 & 0.00006 & 0.001 & 0.00000 & 0.042 & 0.00176 & 4800 & 850 & 8400 & 14050 & 0.009 & 0.00007 \\
\hline 14 & 14 & 0.007 & 0.00005 & 0.048 & 0.00230 & 0.049 & 0.00240 & 4200 & 40800 & 9800 & 54800 & 0.033 & 0.00110 \\
\hline 15 & 15 & 0.008 & 0.00006 & 0.026 & 0.00068 & 0.065 & 0.00423 & 4800 & 22100 & 13000 & 39900 & 0.024 & 0.00058 \\
\hline 16 & 16 & 0.014 & \begin{tabular}{|l|}
0.00020 \\
\end{tabular} & 0.002 & 0.00000 & $\begin{array}{l}0.036 \\
\end{array}$ & 0.00130 & 8400 & 1700 & 7200 & 17300 & 0.010 & 0.00011 \\
\hline 17 & 17 & 0.028 & 0.00078 & 0.016 & 0.00026 & 0.055 & 0.00303 & 16800 & 13600 & 11000 & 41400 & 0.025 & 0.00063 \\
\hline 18 & 18 & 0.023 & 0.00053 & 0.003 & 0.00001 & 0.044 & 0.00194 & 13800 & 2550 & 8800 & 25150 & $\begin{array}{l}0.015 \\
\end{array}$ & \begin{tabular}{|l|l}
0.00023 \\
\end{tabular} \\
\hline 19 & 19 & 0.002 & 0.00000 & 0.037 & 0.00137 & 0.042 & 0.00176 & 1200 & 31450 & 8400 & 41050 & 0.025 & 0.00062 \\
\hline 20 & 20 & 0.008 & 0.00006 & 0.002 & 0.00000 & 0.05 & 0.00250 & 4800 & 1700 & 10000 & 16500 & 0.010 & 0.00010 \\
\hline 21 & 21 & 0.028 & 0.00078 & 0.025 & 0.00063 & 0 & 0.00000 & 16800 & 21250 & 0 & 38050 & 0.023 & \begin{tabular}{|l|l|}
0.00053 \\
\end{tabular} \\
\hline 22 & 22 & 0.022 & 0.00048 & 0.039 & 0.00152 & 0 & 0.00000 & 13200 & 33150 & 0 & 46350 & 0.028 & 0.00079 \\
\hline 23 & 23 & 0.004 & 0.00002 & 0.035 & 0.00123 & 0 & 0.00000 & 2400 & 29750 & 0 & 32150 & 0.019 & 0.00038 \\
\hline 24 & 24 & 0.027 & \begin{tabular}{|l|}
0.00073 \\
\end{tabular} & $\begin{array}{l}0.047 \\
\end{array}$ & 0.00221 & 0 & 0.00000 & 16200 & 39950 & 0 & 56150 & 0.034 & 0.00116 \\
\hline 25 & 25 & 0.017 & 0.00029 & 0.023 & 0.00053 & 0 & 0.00000 & 10200 & 19550 & 0 & 29750 & 0.018 & 0.00033 \\
\hline 26 & 26 & 0.008 & 0.00006 & 0.035 & 0.00123 & 0 & \begin{tabular}{|l|}
0.00000 \\
\end{tabular} & 4800 & 29750 & 0 & 34550 & 0.021 & \begin{tabular}{|l|}
0.00044 \\
\end{tabular} \\
\hline 27 & 27 & 0.026 & 0.00068 & 0.006 & 0.00004 & 0 & 0.00000 & 15600 & 5100 & 0 & 20700 & $\begin{array}{ll}0.013 \\
\end{array}$ & \begin{tabular}{|l|l}
0.00016 \\
\end{tabular} \\
\hline 28 & 28 & 0.004 & 0.00002 & 0.041 & 0.00168 & 0 & 0.00000 & 2400 & 34850 & 0 & 37250 & 0.023 & 0.00051 \\
\hline 29 & 29 & 0.010 & 0.00010 & 0.034 & 0.00116 & 0 & 0.00000 & 6000 & 28900 & 0 & 34900 & 0.021 & 0.00045 \\
\hline 30 & 30 & 0.022 & 0.00048 & 0.021 & 0.00044 & 0 & 0.00000 & 13200 & 17850 & 0 & 31050 & 0.019 & 0.00035 \\
\hline 31 & 31 & 0.005 & 0.00003 & 0.002 & 0.00000 & 0 & 0.00000 & 3000 & 1700 & 0 & 4700 & 0.003 & 0.00001 \\
\hline 32 & 32 & 0.032 & 0.00102 & 0.005 & 0.00003 & 0 & 0.00000 & 19200 & 4250 & 0 & 23450 & 0.014 & 0.00020 \\
\hline 33 & 33 & 0.017 & 0.00029 & 0.011 & 0.00012 & 0 & 0.00000 & 10200 & 9350 & 0 & 19550 & 0.012 & 0.00014 \\
\hline 34 & 34 & 0.024 & 0.00058 & 0.020 & 0.00040 & 0 & 0.00000 & 14400 & 17000 & 0 & 31400 & 0.019 & \begin{tabular}{|l}
0.00036 \\
\end{tabular} \\
\hline 35 & 35 & 0.001 & 0.00000 & 0.005 & 0.00003 & 0 & 0.00000 & 600 & 4250 & 0 & 4850 & 0.003 & 0.00001 \\
\hline 36 & 36 & 0.013 & 0.00017 & 0.021 & 0.00044 & 0 & 0.00000 & 7800 & 17850 & 0 & 25650 & 0.016 & 0.00024 \\
\hline 37 & 37 & 0.006 & 0.00004 & 0.028 & 0.00078 & 0 & 0.00000 & 3600 & 23800 & 0 & 27400 & 0.017 & 0.00028 \\
\hline 38 & 38 & 0.012 & 0.00014 & 0.039 & 0.00152 & 0 & 0.00000 & 7200 & 33150 & 0 & 40350 & 0.024 & 0.00060 \\
\hline 39 & 39 & 0.008 & 0.00006 & 0.041 & 0.00168 & 0 & 0.00000 & 4800 & 34850 & 0 & 39650 & 0.024 & 0.00058 \\
\hline 40 & 40 & 0.020 & 0.00040 & 0.018 & 0.00032 & 0 & 0.00000 & 12000 & 15300 & 0 & 27300 & 0.017 & 0.00027 \\
\hline 41 & 41 & 0.006 & 0.00004 & 0 & 0.00000 & 0 & 0.00000 & 3600 & 0 & 0 & 3600 & 0.002 & 0.00000 \\
\hline 42 & 42 & 0.004 & 0.00002 & 0 & 0.00000 & 0 & 0.00000 & 2400 & 0 & 0 & 2400 & 0.001 & 0.00000 \\
\hline 43 & 43 & 0.009 & 0.00008 & 0 & 0.00000 & 0 & 0.00000 & 5400 & 0 & 0 & 5400 & 0.003 & 0.00001 \\
\hline 44 & 44 & 0.030 & 0.00090 & 0 & 0.00000 & 0 & 0.00000 & 18000 & 0 & 0 & 18000 & 0.011 & 0.00012 \\
\hline 45 & 45 & 0.030 & 0.00090 & 0 & 0.00000 & 0 & 0.00000 & 18000 & 0 & 0 & 18000 & 0.011 & 0.00012 \\
\hline 46 & 46 & 0.008 & 0.00006 & 0 & 0.00000 & 0 & 0.00000 & 4800 & 0 & 0 & 4800 & 0.003 & 0.00001 \\
\hline 47 & 47 & 0.018 & 0.00032 & 0 & 0.00000 & 0 & 0.00000 & 10800 & 0 & 0 & 10800 & 0.007 & 0.00004 \\
\hline 48 & 48 & 0.020 & 0.00040 & 0 & 0.00000 & 0 & 0.00000 & 12000 & 0 & 0 & 12000 & 0.007 & 0.00005 \\
\hline 49 & 49 & 0.010 & 0.00010 & 0 & 0.00000 & 0 & 0.00000 & 6000 & 0 & 0 & 6000 & 0.004 & 0.00001 \\
\hline 50 & 50 & 0.021 & \begin{tabular}{|l|}
0.00044 \\
\end{tabular} & 0 & 0.00000 & 0 & 0.00000 & 12600 & 0 & 0 & 12600 & 0.008 & 0.00006 \\
\hline 51 & 51 & 0.030 & 0.00090 & 0 & 0.00000 & 0 & 0.00000 & 18000 & 0 & 0 & 18000 & 0.011 & 0.00012 \\
\hline 52 & 52 & 0.019 & 0.00036 & 0 & 0.00000 & 0 & \begin{tabular}{|l|}
0.00000 \\
\end{tabular} & 11400 & 0 & 0 & 11400 & 0.007 & 0.00005 \\
\hline 53 & 53 & 0.010 & 0.00010 & 0 & 0.00000 & 0 & 0.00000 & 6000 & 0 & 0 & 6000 & 0.004 & 0.00001 \\
\hline 54 & 54 & 0.049 & 0.00240 & 0 & 0.00000 & 0 & 0.00000 & 29400 & 0 & 0 & 29400 & 0.018 & 0.00032 \\
\hline 55 & 55 & 0.030 & 0.00090 & 0 & 0.00000 & 0 & \begin{tabular}{|c|}
0.00000 \\
\end{tabular} & 18000 & 0 & 0 & 18000 & 0.011 & 0.00012 \\
\hline 56 & 56 & $\begin{array}{l}0.0509 \\
0.009\end{array}$ & 0.00008 & 0 & 0.00000 & 0 & \begin{tabular}{|l|}
0.00000 \\
0.00000
\end{tabular} & 5400 & 0 & 0 & 5400 & 0.003 & 0.00001 \\
\hline 57 & 57 & 0.015 & 0.00023 & 0 & 0.00000 & 0 & 0.00000 & 9000 & 0 & 0 & 9000 & 0.005 & 0.00003 \\
\hline
\end{tabular}




\begin{tabular}{|c|c|c|c|c|c|c|c|c|c|c|c|c|c|}
\hline & \begin{tabular}{|c|}
$\begin{array}{c}\text { Column } \\
1\end{array}$ \\
\end{tabular} & 2 & 3 & 4 & 5 & 6 & 7 & 8 & 9 & 10 & 11 & 12 & 13 \\
\hline $\begin{array}{c}\text { Table } \\
\text { row }\end{array}$ & $\begin{array}{l}\text { Geno- } \\
\text { type }\end{array}$ & $\mathbf{p}_{\mathbf{1 j}}$ & $\mathbf{p}_{1 \mathbf{j}}{ }^{2}$ & $\mathbf{p}_{\mathbf{2 j}}$ & $\mathbf{p}_{2 j}{ }^{2}$ & $\mathbf{p}_{3 \mathbf{j}}$ & $\mathrm{p}_{3 j}{ }^{2}$ & $n_{1 j}$ & $\mathbf{n}_{2 j}$ & $\mathbf{n}_{\mathbf{3 j}}$ & ntot $_{\mathbf{j}}$ & $\mathbf{p c}_{\mathbf{j}}$ & $\mathrm{pc}_{\mathrm{j}}^{2}$ \\
\hline 58 & 58 & 0.011 & 0.00012 & 0 & 0.00000 & 0 & 0.00000 & 6600 & 0 & 0 & 6600 & 0.004 & 0.00002 \\
\hline 59 & 5 & 0 & 0040 & 0 & 0.0 & 0 & 0.0 & 120 & 0 & 0 & 0 & 7 & 0.0 \\
\hline 60 & 60 & 0.021 & 0.00044 & 0 & 0.00000 & 0 & 0.00000 & 12600 & 0 & 0 & 12600 & 0.008 & 0.00006 \\
\hline 61 & Sum & 1.00000 & 0.02284 & 1.00000 & 0.03881 & 1.00000 & 0.05145 & 600000 & 850000 & 200000 & 1650000 & 1.000 & 0.02496 \\
\hline 62 & $\mathrm{Ne}$ & & 43.78 & & 25.77 & & 19.44 & & & & & & 40.07 \\
\hline
\end{tabular}

where:

$\mathrm{p}_{\mathrm{ij}} \quad=$ proportional contribution of the jth genotype in the first population (seed or vegetative lot, or deployed population) to be included in the cumulative assessment

$\mathrm{p}_{2 \mathrm{j}} \quad=$ proportional contribution of the jth genotype in the second population

$\mathrm{p}_{3 \mathrm{j}}=$ proportional contribution of the jth genotype in the third population

$\mathrm{n}_{1 \mathrm{j}} \quad=$ total contribution of the $\mathrm{jth}$ genotype in the first population

$\mathrm{n}_{2 \mathrm{j}} \quad=$ total contribution of the jth genotype in the second population

$\mathrm{n}_{3 \mathrm{j}} \quad=$ total contribution of the $\mathrm{jth}$ genotype in the third population

ntot $_{\mathrm{j}}=$ total contribution of the $\mathrm{jth}$ genotype, summed over populations

$\mathrm{pc}_{\mathrm{j}}=$ proportional contribution of the $\mathrm{jth}$ genotype, over populations 


\section{Appendix 21. Total Production Facility Limit for Stream 2 Material}

See Standards 18.4.3, 18.4.4, 24.41, 32.6, 33.4.3, 33.4.4, 34.3.3.

To maintain forest genetic diversity and associated sustainability, a limit is placed on the total number of controlled parentage program seedlings or vegetative propagules to be deployed from a production facility or facilities. This limit is applied to an entire breeding region/deployment zone, recognizing that there is often more than one tenure holder and/or production facility per region/zone.

The limit is calculated on the basis of:

- total area of target strata in the region/zone,

- the number of seedlings/propagules required per hectare (Trees per ha), and

- the type of material to be produced (seedlings or vegetative propagules).

SEEDLING production facility limits are calculated as follows.

- Where the $\mathrm{Ne}$ is $<30$ (cumulative over the life of the orchard, see Appendix 20):

Planned Total Production Limit (e.g. column 6) = Area of Target Strata (e.g. column 4) x Trees per ha $x 0.25$

- Where the cumulative $N e$ is $\geq 30$, these limits are doubled:

Planned Total Production Limit (e.g. column 7) = Area of Target Strata (e.g. column 4) $x$ Trees per ha $\mathbf{x} 0.50$

VEGETATIVE PROPAGULE production facility limits are calculated as follows.

- Where the $N e$ is $<30$ (cumulative over the life of the orchard, see Appendix 20):

Planned Total Production Limit $=$ Area of Target Strata $x$ Trees per ha $\times 0.20$

- Where the cumulative $N e$ is $\geq 30$, these limits are doubled:

Planned Total Production Limit $=$ Area of Target Strata $x$ Trees per ha $\times 0.40$

The example below illustrates how the size of production facilities may be planned to meet the limits calculated as above.

Stream 2 CPP Production Facility Planning - Seedling Example

\begin{tabular}{|c|c|c|c|c|c|c|}
\hline 1 & 2 & 3 & 4 & 5 & 6 & 7 \\
\hline $\begin{array}{l}\text { Tenure } \\
\text { Holder } \\
\text { (including } \\
\text { unallocated } \\
\text { area) }\end{array}$ & $\begin{array}{c}\text { Total } \\
\text { Breeding } \\
\text { Region/ } \\
\text { Deployment } \\
\text { Zone Area } \\
\text { by Tenure } \\
\text { Holder } \\
\\
\text { (ha) }\end{array}$ & $\begin{array}{c}\text { Operable } \\
\text { Area } \\
\text { Within } \\
\text { Region/Zone } \\
\text { by Tenure } \\
\text { Holder }\end{array}$ & $\begin{array}{c}\text { Area of } \\
\text { Target } \\
\text { Strata } \\
\text { by } \\
\text { Species and } \\
\text { Tenure } \\
\text { Holder * } \\
\\
\text { (ha) }\end{array}$ & $\begin{array}{c}\text { Estimated } \\
\text { Plants } \\
\text { Required for } \\
\mathbf{1 0 0 \%} \text { Planting } \\
\text { of Area of } \\
\text { Target } \\
\text { Strata } \\
\\
\\
\text { (\# seedlings) }\end{array}$ & $\begin{array}{c}\text { Planned } \\
\text { Total } \\
\text { Production } \\
\text { Limit, one or } \\
\text { more } \\
\text { production } \\
\text { facilities } \\
\text { (cumulative } \\
\text { Ne<30) } \\
\text { (\# seedlings) } \\
\end{array}$ & $\begin{array}{c}\text { Planned } \\
\text { Total } \\
\text { Production } \\
\text { Limit, one or } \\
\text { more } \\
\text { production } \\
\text { facilities } \\
\text { (cumulative - } \\
\text { Ne } \geq 30 \text { ) } \\
\text { (\# seedlings) } \\
\end{array}$ \\
\hline $\mathrm{X}$ & $1,595,000$ & $1,096,250$ & 150,000 & $270,000,000$ & $67,500,000$ & $135,000,000$ \\
\hline$Y$ & 957,000 & 817,750 & 87,000 & $156,000,000$ & $39,000,000$ & $78,000,000$ \\
\hline $\mathrm{Z}$ & 638,000 & 478,500 & 50,000 & $90,000,000$ & $22,500,000$ & $45,000,000$ \\
\hline Unallocated & 445,000 & 310,000 & 35,000 & $63,000,000$ & $15,750,000$ & $31,500,000$ \\
\hline Totals & $3,635,000$ & $2,702,500$ & 322,000 & $579,000,000$ & $144,750,000$ & $289,500,000$ \\
\hline
\end{tabular}

*Target strata refers to the area to be regenerated to the species produced by the production facility, not yield strata. 


\section{Appendix 22. Request for Deployment Variance for Stream 2 Material}

See Standard 18.4.8.

\section{REQUESTING AGENCY}

Agency Name

\section{DATE}

Mailing Address Contact

Phone Fax

E-mail

\section{TYPE OF VARIANCE REQUESTED}

Annual Standing

Species Category of Material

REASONS FOR REQUEST (Include Standards Not Met)

\section{CROP DESCRIPTION}

Registered Lot Number Seed Vegetative

Breeding Region/Deployment Zone

Production Facility Number Effective Population Size

Latitude Elevation: Mean

Longitude Elevation: Range

Legal Location UTM Northing

UTM Easting

\section{PROPOSED DEPLOYMENT}

Breeding Region/Deployment Zone

Production Facility Number Effective Population Size

Latitude Elevation: Mean

Longitude Elevation: Range

Legal Location UTM: Northing

UTM: Easting

Years of Deployment Total Number of Seedlings or Propagules

MONITORING AND REPORTING SCHEDULE 


\section{Appendix 23. Request for Planting Variance for Research Material}

See Standards 23.1 and 23.7.

\section{REQUESTING AGENCY}

Agency Name

DATE

Mailing Address Contact

Phone Fax

E-mail

\section{TYPE OF VARIANCE REQUESTED}

Annual Standing

Species Category of Material

\section{RESEARCH PLAN REFERENCE}

\section{MATERIAL DESCRIPTION}

Origin: For progeny tests of local material identify seed zone/breeding region

\section{Attach additional pertinent information.}

\section{PROPOSED AREA OF TESTING}

Zone

Elevation

Latitude Longitude

Legal Location

UTM Northing

UTM Easting

Test Size (ha)

BENEFIT/RISK ASSESSMENT Where non-local materials are involved, attach a discussion of the following topics, including relevant experience and referenced literature: a) Expected benefits; b) Estimated risks and consequences of: gene flow to native populations, invasiveness to Alberta forests, development of centres for distribution of pests and release of toxins.

MONITORING AND REPORTING SCHEDULE 


\section{Appendix 24. Research Program Plan - Contents}

\section{See Standard 25.1.}

The following topics are to be addressed in a Research Program Plan. A proponent is advised to submit a letter of intent to the Department prior to developing a program plan.

\section{Introduction}

- Project title

- Research proponents

- Research problem

- Traits of interest

- Research objective(s)

- Hypothesis test(s)

- Deployment objectives where applicable

- Risk/benefit assessment where applicable ${ }^{1}$.

- Link to controlled parentage program, if relevant

\section{Materials}

- Target species

- Genetic test material (provenances, populations, families, etc.)

- Genetic test material origin

- Physical test material (seedling, seed, rooted cuttings, stock type, etc.)

- Controls

- Physical test environment (e.g. lab, green house, field test)

- Test environment conditions (field test site location climate, soils, etc.; lab or greenhouse test environment conditions)

\section{Methods}

- Research hypothesis test(s)

- Experimental design

- Data collection

- Criteria for selection and protection of test site(s) if applicable

- Description of assessment methods and procedures

- Analysis procedures

\section{Anticipated Deliverables \\ References}

\section{${ }^{1}$ e.g. Volume/growth expectations, benefit(s)}

Genetic make-up (i.e. based on flowering, leaf morphology analysis, DNA analysis)

Gender

Fertility (hybridization potential [phenology, viability, control])

Suckering potential (possible control, if a genetically modified organism (GMO) may be specific to type)

Planting location, design, timeline, size

Buffer requirements, maintenance standards

Harvesting method and clean-up

Potential for release of toxins

Centre of insect and disease outbreaks

Potential to ameliorate risk (e.g. silviculture practices)

Invasiveness

Ecosystem impact 


\section{Appendix 25. Unique Identifier Codes}

See Standard 25.5.

UNIQUE IDENTIFIER

\begin{tabular}{|l|l|l|l|l|l|l|l|l|l|l|l|l|l|}
\hline $\begin{array}{l}\text { Field } \\
\text { Number }\end{array}$ & 1 & 2 & 3 & 4 & 5 & 6 & 7 & 8 & 9 & 10 & 11 & 12 & 13 \\
\hline Example & $\mathrm{D}$ & $\mathrm{M}$ & 0 & 0 & 0 & 4 & 5 & $\mathrm{~A}$ & $\mathrm{~W}$ & 0 & 0 & 1 & $\mathrm{~S}$ \\
\hline
\end{tabular}

Fields 1 - 7 provide the unique genotype and are compulsory fields.

Fields 8 - 13 provide the material description and are optional fields.

FIELD DESCRIPTION WITH EXAMPLE

\begin{tabular}{|l|l|l|l|l|}
\hline $\begin{array}{l}\text { Field } \\
\text { Numbers }\end{array}$ & $\begin{array}{l}\text { Character } \\
\text { Type }\end{array}$ & Description & $\begin{array}{l}\text { Example } \\
\text { DM00045AW001S }\end{array}$ & $\begin{array}{l}\text { Example } \\
\text { Description }\end{array}$ \\
\hline $1-2$ & alpha & Agency Code & DM & $\begin{array}{l}\text { Daishowa- } \\
\text { Marubeni }\end{array}$ \\
\hline $3-7$ & numeric & $\begin{array}{l}\text { Agency's unique } \\
\text { clone identification } \\
\text { number for the parent } \\
\text { tree/selection/clone }\end{array}$ & 00045 & Clone number 45 \\
\hline $8-9$ & alpha & Species Code & AW & Trembling aspen \\
\hline $10-12$ & numeric & $\begin{array}{l}\text { Agency's } \\
\text { identification number } \\
\text { for the individual or } \\
\text { collection }\end{array}$ & 001 & First collection \\
\hline 13 & alpha & Type of material & S & Seed lot \\
\hline
\end{tabular}

Each agency's identification number for a parent tree/selection/clone (fields 3 - 7) is a unique number for that agency, and is to be used only once by that agency, regardless of the species.

All alpha fields are in uppercase letters only.

\section{CODES}

Type of Material (field 13): grafted ramet

rooted ramet

seed lot

scion

root

flower buds

pollen

whole tree/seedling

other 
AGENCY CODES (fields 1 - 2):

\begin{tabular}{|c|c|}
\hline Agency Name & Code \\
\hline 770538 ALBERTA LTD & $\mathrm{AA}$ \\
\hline AINSWORTH LUMBER COMPANY & $\mathrm{AI}$ \\
\hline ALBIAN SANDS ENERGY INC & AS \\
\hline ALBERTA-PACIFIC FOREST INDUSTRIES INC & $\mathrm{AF}$ \\
\hline ALBERTA PLYWOOD LTD & $\mathrm{AP}$ \\
\hline ALBERTA TREE IMPROVEMENT AND SEED CENTER & AT \\
\hline ANC TIMBER LTD & AN \\
\hline ATLAS LUMBER (ALBERTA) LTD & $\mathrm{AL}$ \\
\hline BLUE RIDGE LUMBER & BR \\
\hline BOSS TIMBER LTD & BT \\
\hline BOUCHER BROTHERS LUMBER & BB \\
\hline BUCHANAN LUMBER & $\mathrm{BL}$ \\
\hline CANADIAN FOREST PRODUCTS LTD, GRANDE PRAIRIE & CG \\
\hline CANADIAN FOREST PRODUCTS LTD, HINES CREEK & $\mathrm{CH}$ \\
\hline CARDINAL RIVER COALS & $\mathrm{CR}$ \\
\hline CYPRESS HILLS INTERPROVINCIAL PARK & $\mathrm{CY}$ \\
\hline DAISHOWA-MARUBENI INTERNATIONAL LTD & DM \\
\hline FOOTNER FOREST PRODUCTS & $\mathrm{FF}$ \\
\hline FOREST RESOURCE IMPROVEMENT ASSOCIATION & FR \\
\hline HANSEN FOREST PRODUCTS & $\mathrm{HF}$ \\
\hline HUALLEN SEED ORCHARD COMPANY & $\mathrm{HU}$ \\
\hline INDIAN AND NORTHERN AFFAIRS, CANADA & IN \\
\hline LAND AND FOREST DIVISION, CLEARWATER AREA & LC \\
\hline LAND AND FOREST DIVISION, FOOTHILLS AREA & LF \\
\hline LAND AND FOREST DIVISION, LAC LA BICHE AREA & LL \\
\hline LAND AND FOREST DIVISION, LESSER SLAVE AREA & LS \\
\hline LAND AND FOREST DIVISION, PEACE AREA & LP \\
\hline LAND AND FOREST DIVISION, SMOKY AREA & LG \\
\hline LAND AND FOREST DIVISION, SOUTHERN ROCKIES AREA & LR \\
\hline LAND AND FOREST DIVISION, UPPER HAY AREA & LU \\
\hline LAND AND FOREST DIVISION, WATERWAYS AREA & LW \\
\hline LAND AND FOREST DIVISION, WOODLANDS AREA & LO \\
\hline LAND AND FOREST DIVISION, PRFN & LN \\
\hline L H REHN LUMBER LTD & RE \\
\hline LITTLE RED RIVER FORESTRY LTD & RR \\
\hline LUSCAR LTD -COAL VALLEY MINE & $\mathrm{CV}$ \\
\hline LUSCAR LTD -GREGG RIVER MINE & GR \\
\hline LUSCAR LTD -LINE CREEK MINES & $\mathrm{CM}$ \\
\hline LUSCAR LTD -OBED MOUNTAIN MINE & $\mathrm{OM}$ \\
\hline MANNING DIVERSIFIED FOREST PRODUCTS & $\mathrm{MD}$ \\
\hline MEDICINE LODGE TIMBER PRODUCTS & ML \\
\hline METIS SETTLEMENTS TRANSITION COMMISSION & MS \\
\hline MILLAR WESTERN FOREST PRODUCTS - BOYLE & $\mathrm{MB}$ \\
\hline MILLAR WESTERN FOREST PRODUCTS - WHITECOURT & MW \\
\hline MOSTOWICH LUMBER LTD & $\mathrm{MO}$ \\
\hline NORTHLAND FOREST PRODUCTS LTD & NF \\
\hline PEACE RIVER PULP LTD. & PR \\
\hline ROCKY WOOD PRESERVERS LTD & RW \\
\hline SEEHTA FOREST PRODUCTS & $\mathrm{SF}$ \\
\hline SLAVE LAKE PULP LTD. & SA \\
\hline SMOKY RIVER COALS LIMITED & SR \\
\hline SOSNOWSKI, MIKE & SM \\
\hline
\end{tabular}




\begin{tabular}{|l|l|}
\hline Agency Name & Code \\
\hline SPRAY LAKES SAWMILLS LTD & SL \\
\hline ST JEAN LUMBER LTD & SJ \\
\hline SUNCOR ENERGY INC & SE \\
\hline SUNDANCE FOREST INDUSTRIES LTD & SU \\
\hline SUNPINE FOREST PRODUCTS LTD & SP \\
\hline SYNCRUDE CANADA LTD & SC \\
\hline TALL PINE TIMBER COMPANY LTD & TP \\
\hline TIMEU FOREST PRODUCTS & TF \\
\hline TOLKO INDUSTRIES LTD - HIGH PRAIRIE & TH \\
\hline TOLKO INDUSTRIES LTD - HIGH LEVEL & TL \\
\hline VANDERWELL CONTRACTORS LTD & VC \\
\hline WABASCA LAKES SAWMILL COMPANY LTD & WL \\
\hline WALLACH, PAUL & WP \\
\hline WELDWOOD OF CANADA LTD & WW \\
\hline WESTERN BOREAL ASPEN CORP & WB \\
\hline WEYERHAEUSER COMPANY LTD, DRAYTON VALLEY & WD \\
\hline WEYERHAEUSER COMPANY LTD, EDSON & WE \\
\hline WEYERHAEUSER COMPANY LTD, GRANDE CACHE & WC \\
\hline WEYERHAEUSER COMPANY LTD, GRANDE PRAIRIE & WG \\
\hline WEYERHAEUSER COMPANY LTD, SLAVE LAKE & WS \\
\hline ZAMA MILLS & ZM \\
\hline PARENT MATERIAL COLLECTIONS MADE PRIOR TO May 1, 2003 & XX \\
\hline
\end{tabular}


SPECIES CODES (Fields 8-9):

Section 1: Pure Species

\begin{tabular}{|l|l|l|l|l|}
\hline \multicolumn{1}{|c|}{ Species Code } & \multicolumn{1}{c|}{ Family } & \multicolumn{1}{c|}{ Genus } & \multicolumn{1}{c|}{ Species } & \multicolumn{1}{c|}{ Common Name } \\
\hline BW & Betulaceae & Betula & papyrifera & paper (white) birch \\
\hline PL & Pinaceae & Pinus & contorta & lodgepole pine \\
\hline PJ & Pinaceae & Pinus & banksiana & jack pine \\
\hline PA & Pinaceae & Pinus & albicaulis & whitebark pine \\
\hline PF & Pinaceae & Pinus & flexilis & limber pine \\
\hline LA & Pinaceae & Larix & lyallii & alpine larch \\
\hline LT & Pinaceae & Larix & laricina & tamarack \\
\hline LW & Pinaceae & Larix & occidentalis & western larch \\
\hline SW & Pinaceae & Picea & glauca & white spruce \\
\hline SE & Pinaceae & Picea & engelmannii & Engelmann spruce \\
\hline SB & Pinaceae & Picea & mariana & black spruce \\
\hline FD & Pinaceae & Pseudotsuga & menziesii & Douglas-fir \\
\hline FB & Pinaceae & Abies & balsamea & balsam fir \\
\hline FA & Pinaceae & Abies & lasiocarpa & alpine fir \\
\hline AB & Salicaceae & Populus & alba & white poplar \\
\hline PB & Salicaceae & Populus & balsamifera & balsam poplar \\
\hline DA & Salicaceae & Populus & davidiana & Chinese/Korean aspen \\
\hline DE & Salicaceae & Populus & deltoides & plains cottonwood \\
\hline GR & Salicaceae & Populus & grandidentata & bigtooth aspen \\
\hline LA & Salicaceae & Populus & laurifolia & - \\
\hline MA & Salicaceae & Populus & maximowiczii & poplar (Japan) \\
\hline NI & Salicaceae & Populus & nigra & poplar \\
\hline SA & Salicaceae & Populus & sargentii & sargentii poplar \\
\hline TA & Salicaceae & Populus & tremula & European aspen \\
\hline AW & Salicaceae & Populus & tremuloides & trembling aspen \\
\hline TR & Salicaceae & Populus & trichocarpa & black cottonwood \\
\hline
\end{tabular}

Section 2: Hybrids

\begin{tabular}{|l|l|l|l|l|}
\hline \multicolumn{1}{|c|}{ Species Code } & Family & Genus & Species & Common Name \\
\hline $\begin{array}{l}\text { Codes to be } \\
\text { developed in the } \\
\text { future }\end{array}$ & & & & \\
\hline
\end{tabular}




\section{Appendix 26. Genetic Test Establishment Report - Contents}

See Standards 27.1 and 30.12.1.

At a minimum, the genetic test establishment report will contain a clear description and/or listing of the following:

\section{Header}

- Program

- Agency / cooperators

- Trial code

- Site name

- Reference to associated Controlled Parentage Program (CPP) or Research Plan

- List of associated trials (i.e. tests containing the same genetic material)

\section{Test Material}

- Listing of seed or vegetative lots including genetic identity and genetic origin

\section{Controls}

- Listing of seed or vegetative lots including genetic identity and genetic origin

\section{Planting Stock}

- Description and location of sowing and growing, including nursery, sowing date, lift date and stock type; also any relevant descriptive details relating to growing, lifting, packing and delivery

\section{Experimental Design}

- Type (e.g. Alpha, randomized complete block)

- Number of replicates

- Number of blocks/rep

- Plot size and shape

- Include outputs from design generation program showing treatment randomizations and replicate/block assignments

- Border row(s) description

\section{Test Site}

- Include completed Genetic Test Site Information Form (see Appendix 29) and access map

\section{Site Protection}

- Legal (e.g. DRS)

- Physical (e.g. fencing)

\section{Site Preparation}

- Method

- Timing

- Contractor

Site Layout

- Method

- Spacing

\section{Field Marking}

- Description

- $\%$ trees marked 


\section{Planting}

- Names of contractors and key supervisors

- Dates

- Weather

- Planter allocation description (e.g. one planter/rep)

\section{Map or Maps}

- Must unambiguously define genetic and experimental design identity of each tree

\section{Test Content File}

- Attach electronic listing as per Standard 27.1

\section{References}




\section{Appendix 27. Genetic Test Measurement Report - Contents}

See Standards 27.4, 30.8.1, 30.12.2.

At a minimum, the genetic test measurement report will contain a clear description and/or listing of the following.

\section{Introduction}

- Trial description and objective(s)

- Applicable CPP or RP Plan

- Measurement objectives

- Measurement schedule

- Measuring agency and personnel

\section{Methods}

- Variables assessed and measured

- Assessment and measurement methods, procedures and equipment

- Quality control procedures (e.g. measurement procedures, data handling and verification procedures, field measurement spot checking and sampling intensity, measurement instrument calibration)

\section{Results}

- Data dictionary containing variable listing, description of values of variables, position in file and file format

- Data format (ASCII standard)

- Measurement start and completion dates

- Data summaries

- Tree counts by site, replicate and treatment

- Appropriate site means and ranges for assessed traits

- Trait means by replicate

- Trait means by treatment

- Attach verified raw data set to be submitted electronically with report and in accordance with data handling standards outlined in Standard 27.0.

Notes

- Significant items of interest or concern relating to assessment or data 


\section{Appendix 28. Genetic Test Analysis Report - Contents}

See Standard 30.1.

At a minimum, the genetic test analysis report will contain a clear description and/or listing of the following.

\section{Name of Relevant CPP or RP Plan}

\section{Genetic Test Analysis Report}

- Trial identity

- Filename of validated dataset (submitted with Genetic Test Measurement Report; see Appendix 27 for contents)

- Objective(s) of analyses

- Editing procedure used to convert validated dataset to dataset analyzed (e.g. treatment of outliers, values deleted, reasoning)

- Analytical procedure

- Method (e.g. ANOVA, BLP)

- Model

- Expected mean squares where appropriate

Summary Statistics for Traits of Interest (e.g. height and survival)

Estimates of Genetic Parameters (e.g. breeding values, heritability and genetic correlations)

- Showing method and formulae used

\section{Standard Errors}

- Calculated for parameter estimates used to calculate heritability and genetic correlations

- Calculation methods to be shown

\section{Dataset Analyzed}

- Submitted in electronic format with this analysis report

\section{Reference to Additional Relevant Reports}

- Research Plan or Controlled Parentage Program Plan

- Establishment Report

- Measurement Report 


\section{Appendix 29. Genetic Test Site Information Form}

See Standard 30.3.2.

\begin{tabular}{|c|c|c|}
\hline \multicolumn{2}{|c|}{ Relevant CPP or RP Plan } & \\
\hline \multicolumn{2}{|c|}{ Proponent responsible for test site } & \\
\hline \multicolumn{2}{|c|}{ Date form completed/updated } & \\
\hline \multicolumn{2}{|c|}{ Trial code (provided by the Department) } & \\
\hline \multicolumn{2}{|c|}{ Site name (local feature or landmark) } & \\
\hline \multicolumn{2}{|c|}{$\begin{array}{l}\text { Land reservation (type: e.g. ISP or MLL, } \\
\text { date, identification number) }\end{array}$} & \\
\hline \multirow[t]{5}{*}{ Site location } & Latitude & \\
\hline & Longitude & \\
\hline & Legal & \\
\hline & UTM Northing (optional) & \\
\hline & UTM Easting (optional) & \\
\hline \multirow[t]{17}{*}{$\begin{array}{l}\text { Site } \\
\text { information }\end{array}$} & Elevation $(\mathrm{m})$ & \\
\hline & Slope (range and mean) & \\
\hline & Position on slope & \\
\hline & Aspect & \\
\hline & Opening size & \\
\hline & Parent material & \\
\hline & Soil classification & \\
\hline & Natural region & \\
\hline & Natural subregion & \\
\hline & $\begin{array}{l}\text { Original species } \\
\text { composition and cover type }\end{array}$ & \\
\hline & Site classification/type & \\
\hline & Productivity & \\
\hline & Effective rooting depth & \\
\hline & Soil type and depth & \\
\hline & Drainage class & \\
\hline & Nutrient class & \\
\hline & Other soil information & \\
\hline \multirow[t]{3}{*}{ Site history } & Harvest date & \\
\hline & $\begin{array}{l}\text { Post harvest (site prep) } \\
\text { treatment, date(s) }\end{array}$ & \\
\hline & $\begin{array}{l}\text { Other development info } \\
\text { (fence, culvert, etc.) }\end{array}$ & \\
\hline \multirow[t]{2}{*}{ Maps (attach) } & Site access (sketch ok) & \\
\hline & Site (cutblock) map to scale & \\
\hline
\end{tabular}




\section{Appendix 30. Example of Data Collection Map and Corresponding Form}

\section{See Standard 30.5.1.}

\section{EXAMPLE OF DATA COLLECTION FORM (Excel Sheet)}

This form may be used as a template for any trial. Therefore, not all columns will be relevant to all trials. For silvicultural trials there will be a treatment column; for genetics trials there may be a provenance and clone column. Although the site code must exist in the file, the column can be hidden when printing out the sheets for data entry purposes. Each year that the file is added to will require the insertion of a new column for the trait being measured. For example: $\mathrm{FHt} 99|\mathrm{FHt} 00| \mathrm{FHt} 01|\mathrm{FCp} 99| \mathrm{FCp} 00 \mid \mathrm{FCp} 01$, etc. It is very useful to print out at least the last year's measurements when preparing data sheets, while hiding all other information. This can also be done if data is being collected directly onto a computer.

\section{(FHt99: Fall Height 1999)}

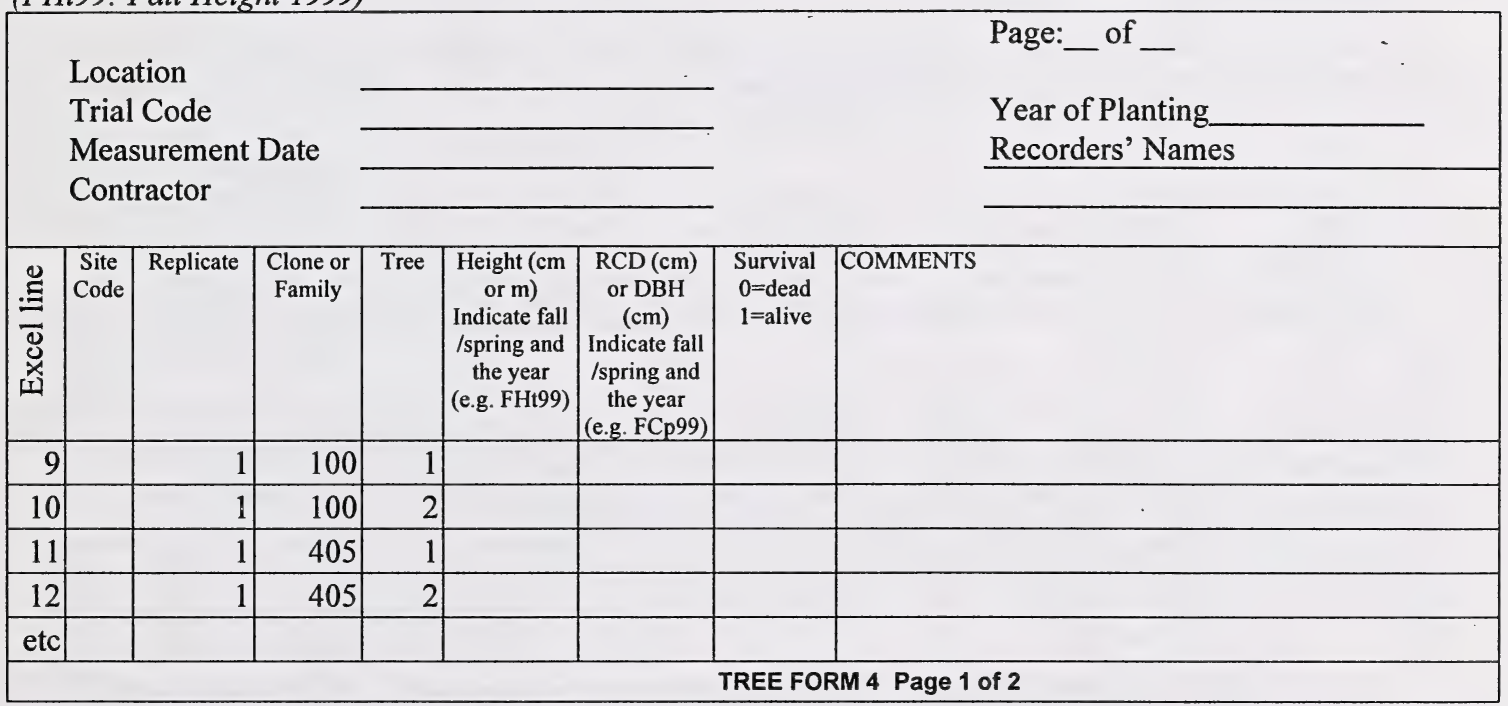




\section{MAP GUIDE}

Page_ of

Location

Plantation name or trial code

Measurement date

Year of planting

Contractor

Initials of recorders

On the grid indicate the tie point, direction of travel throughout plantation/trial.

Show North arrow

Include replicate, clone or treatment and tree number per grid square.

Clearly indicate Start point of map to link with

data file sequence.

\begin{tabular}{|c|c|c|c|c|c|c|c|c|c|c|c|c|c|c|c|c|c|c|}
\hline & & & & & & & & & & & & & & & & & & \\
\hline & & & $x$ & $x$ & $x$ & $x$ & $x$ & $x$ & $x$ & $x$ & $x$ & $x$ & $x$ & $x$ & & & & \\
\hline & & & $x$ & $x$ & $k$ & $8 x$ & A & & $(x)$ & $5 x$ & ब & $\sqrt{x}$ & $x$ & $x$ & & & & \\
\hline & & & $\mathrm{X}$ & $x$ & & & & & & & & & $\bar{x}$ & $x$ & & & & \\
\hline & & & $x$ & $x$ & & & & & & & & & $x$ & $x$ & & & & \\
\hline & & & $\mathrm{x}$ & $\bar{x}$ & & & & & & & & & $x$ & $x$ & & & & \\
\hline & & & $x$ & $x$ & & & & & & & & & $x$ & $x$ & & & & \\
\hline & & & $x$ & $\mathrm{X}$ & & & & & & & & & $\mathrm{X}$ & $x$ & & & & \\
\hline & & & $x$ & $\bar{x}$ & & & & & & & & & $x$ & $\mathrm{x}$ & & & & \\
\hline & & & $x$ & $\mathrm{x}$ & & & & & & & & & $x$ & $\mathrm{x}$ & & & & \\
\hline & & & $x$ & $x$ & Etc. & & & & & & & & $x$ & $x$ & & & & \\
\hline & & & $x$ & $x$ & \begin{tabular}{|l|}
$803-2$ \\
\end{tabular} & & & & & & & & $\mathrm{X}$ & $x$ & & & & \\
\hline & & & $x$ & $x$ & \begin{tabular}{|l|}
$803-1$ \\
\end{tabular} & & & & & & & & $\mathrm{X}$ & $x$ & & & & \\
\hline & & & $x$ & $\mathrm{X}$ & \begin{tabular}{|l|}
$405-2$ \\
\end{tabular} & & & & & & & & $\mathrm{X}$ & $x$ & & & & \\
\hline & & & $x$ & $x$ & \begin{tabular}{|l|}
$405-1$ \\
\end{tabular} & & & & & & & & $x$ & $\mathrm{x}$ & & $\pi$ & & \\
\hline & & & $x$ & $x$ & \begin{tabular}{|c|}
$101-2$ \\
\end{tabular} & & & & & & & & $x$ & $x$ & & & & \\
\hline & & & $x$ & $x$ & \begin{tabular}{|l|}
$101-1$ \\
\end{tabular} & & & & & & & & $\mathrm{x}$ & $x$ & & & & \\
\hline & & & $x$ & $x$ & $\mathrm{~A}$ & & U $x$ & & (3) $x$ & (6) & $4 x$ & $x$ & $x$ & $x$ & & & & \\
\hline & & & $x$ & $x$ & $x$ & $x$ & $x$ & $x$ & $x$ & $x$ & $x$ & $x$ & $x$ & $x$ & & & & \\
\hline & & & & & & & & & & & & & & & & $\mathrm{N}$ & & \\
\hline & & & & & Start & & & & & & & & & & & & & \\
\hline & & & & & & & & & 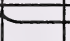 & & 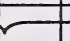 & & & & & & & \\
\hline & & & & & & Rep- & 1 & & & & Rep- & 2 & & & & & & \\
\hline & & & & & & & & & & & & & & & & & & \\
\hline & & $X=I$ & Borde & ar tre & & & & & & & & & & & & & & \\
\hline & & & & & & & & & & & & & & & & & & \\
\hline
\end{tabular}

Include as many grids as needed to cover plantation/trial and include tie points between maps. Indicate border trees with shading or X's.

Comments:

MAP GRID 


\title{
Appendix 31. Calculation of Genetic Worth for Vegetative Lots and Orchard Seedlots
}

\author{
See Standards 31.2, 33.3, 33.6, 34.1, 34.5. See also Appendix 28.
}

\section{INTRODUCTION}

Genetic worth $(\mathrm{GW})$ is an estimate of the expected performance of a vegetative or seed lot, and refers to individual traits such as height, volume or wood density. It is calculated as the average breeding value (BV) of genotypes represented in the lot, weighted by genotypic contribution (for vegetative lots), or by an estimate of the proportion of gametes contributed by each genotype (for seedlots). The genetic worth of orchard seedlots may need to be adjusted for genetic (pollen) contamination and supplemental mass pollination (SMP).

\section{APPLICABILITY}

Where application or claim for genetic gain is contingent on the genetic worth of a seedlot or seedlots used for reforestation, genetic worth shall be calculated according to the protocols outlined here. Where no claim for genetic gain applies, genetic worth, for the purpose of lot registration, can be considered to be 0 .

\section{ASSUMPTIONS AND CALCULATIONS}

1. It is assumed that phenotypic selection from wild stands will yield, on average, a $2 \%$ gain in height, where selections have been made intensively and there is documented height over age superiority. This figure may be used as a BV for selected clones until reliable test results are available (see Table 1, Standard 31.5). Individuals in seedling seed orchards will be assigned a BV of $1 \%$ until reliable test results are available.

2. BVs for height, estimated from genetic test data, are calculated relative to unselected or operational lot controls appropriate to the given Controlled Parentage Program (CPP), or to the mean performance of progeny of parents in the breeding population of the CPP. Where BVs are calculated relative to the mean of tested parents (rather than relative to control lots), and selections were made intensively as described in Item 1 above, $2 \%$ may be added to the calculated BV for clonal orchards and $1 \%$ for open pollinated seedling orchards.

3. The genetic correlation between height at rotation age and height at assessment age is based on Lambeth's (1980) model $^{1}$, and may be calculated as:

$$
r_{a}(j, m)=1.02+0.308 \operatorname{Ln}(j / m)
$$

where

$$
\begin{aligned}
& \mathrm{r}_{\mathrm{a}}(\mathrm{j}, \mathrm{m})=\text { the additive genetic correlation between performance at ages } \mathrm{j} \text { and } \mathrm{m} \text {, assessment } \\
& \text { (juvenile) and rotation (mature) ages respectively; and } \\
& \mathrm{Ln}(\mathrm{j} / \mathrm{m})=\text { the natural logarithm of the age ratio } \mathrm{j} / \mathrm{m} \text {. }
\end{aligned}
$$

${ }^{1}$ Other options will be considered by the Department on a case-by-case basis.

4. It will be assumed that the genetic worth of contaminating pollen is 0 , unless evidence to the contrary exists.

5. $\mathrm{p}_{\mathrm{i}}$, the proportion of gametes produced by genotype $\mathrm{i}$, will be estimated as follows. 


\section{A. Seed lots from clonal and/or uneven-aged seed orchards}

Method of estimation will depend on the number of genotypes contributing to the crop. See Table 1 . Where genotypic frequencies are calculated based on both male and female contributions, male and female genotypic contributions may be calculated separately. Otherwise, male and female contributions for genotype $\mathrm{i}$ are both assumed to equal $\mathrm{p}_{\mathrm{i}}$.

Table 1. Method of genotypic contribution estimation for clonal and/or uneven aged orchards

\begin{tabular}{|c|l|}
\hline $\begin{array}{c}\text { Number of genotypes } \\
\text { contributing }\end{array}$ & \multicolumn{1}{|c|}{ Method of estimation of genotypic contribution } \\
\hline Fewer than 50 & $\begin{array}{l}\text { As per Table } 1, \text { Appendix } 37 . \\
\text { Alternatively, if collections are made on a clonal basis, cone volume } \\
\text { per clone may be used to estimate } \mathrm{p}_{\mathrm{i}} .\end{array}$ \\
\hline $50-74$ & $\begin{array}{l}\text { Sampling level: } 50 \% \text { sample of contributing trees } \\
\text { Material assessed: count of female flowers or cones } \\
\text { Alternatively, if collections are made on a clonal basis, cone volume } \\
\text { per clone may be used to estimate } \mathrm{p}_{\mathrm{i}} .\end{array}$ \\
\hline 75 or more & $\begin{array}{l}\text { Genotypic frequency in the cone-bearing population may be used to } \\
\text { estimate } \mathrm{p}_{\mathrm{i}} \text {. } \\
\text { Example: Clone } \mathrm{x} \text { has } 15 \text { ramets that bear cones out of an orchard } \\
\text { total of } 250 \text { cone-bearing ramets. } \mathrm{p}_{\mathrm{i}}=15 / 250=0.06 . \\
\text { Alternatively, if collections are made on a clonal basis, cone volume } \\
\text { per clone may be used to estimate } \mathrm{p}_{\mathrm{i}} .\end{array}$ \\
\hline
\end{tabular}

\section{B. Seed lots from even-aged half-sibling family orchards}

Method of estimation will depend on number of families contributing to the crop. See Table 2. Where genotypic frequencies are calculated based on both male and female contributions, male and female genotypic contributions may be calculated separately. Otherwise, male and female contributions for family $i$ are both assumed to equal $p_{i}$.

Table 2. Method of genotypic contribution estimation for even-aged half-sibling family orchards

\begin{tabular}{|c|l|}
\hline $\begin{array}{c}\text { Number of families } \\
\text { contributing }\end{array}$ & \multicolumn{1}{c|}{ Method of estimation of genotypic contribution } \\
\hline Fewer than 25 & $\begin{array}{l}\text { As per Table } 1, \text { Appendix } 37 . \\
\text { Alternatively, if collections are made on a family basis, cone volume } \\
\text { per family may be used to estimate } p_{i}\end{array}$ \\
\hline $25-37$ & $\begin{array}{l}\text { Sampling level: } 50 \% \text { sample of contributing trees. } \\
\text { Material assessed: count of female flowers or cones. } \\
\text { Alternatively, if collections are made on a family basis, cone volume } \\
\text { per family may be used to estimate } p_{i} .\end{array}$ \\
\hline 38 or more & $p_{i}=$ proportion of orchard trees of family $\mathrm{i}$ \\
\hline
\end{tabular}




\section{Vegetative lots}

$\mathrm{p}_{\mathrm{i}} \quad=$ proportion of vegetative propagules produced by genotype $\mathrm{i}$

\section{SEVERAL CASES ARE CONSIDERED BELOW.}

CASE 1. Seed or vegetative lot produced in production facility with no genetic contamination or supplemental mass pollination (SMP)

$$
\mathbf{G W}=\sum\left(\mathbf{p}_{\mathbf{i}} \mathbf{B V}\right)
$$

where

$$
\begin{aligned}
& \mathrm{GW}=\text { genetic worth of the seed or vegetative lot; } \\
& \mathrm{BV}_{\mathrm{i}}=\text { breeding value of genotype (clone or family) } \mathrm{i}
\end{aligned}
$$

Example 1: Breeding values and genotypic contributions as shown in table below.

\begin{tabular}{|r|r|r|r|}
\hline Genotype & \multicolumn{1}{|c|}{$\mathbf{p}_{\mathbf{i}}$} & \multicolumn{1}{c|}{$\mathbf{B V}_{\mathbf{i}}$} & $\mathbf{p}_{\mathbf{i}}{ }^{{ }^{*}} \mathbf{B V _ { \mathbf { i } }}$ \\
\hline 1 & 0.10 & 0.27 & 0.027 \\
\hline 2 & 0.07 & 0.20 & 0.014 \\
\hline 3 & 0.05 & 0.15 & 0.0075 \\
\hline 4 & 0.09 & 0.22 & 0.0198 \\
\hline 5 & 0.14 & 0.06 & 0.0084 \\
\hline 6 & 0.07 & 0.10 & 0.007 \\
\hline 7 & 0.05 & 0.08 & 0.004 \\
\hline 8 & 0.04 & 0.12 & 0.0048 \\
\hline 9 & 0.03 & 0.02 & 0.0006 \\
\hline 10 & 0.11 & 0.02 & 0.0022 \\
\hline 11 & 0.07 & 0.02 & 0.0014 \\
\hline 12 & 0.06 & 0.02 & 0.0012 \\
\hline 13 & 0.05 & 0.02 & 0.001 \\
\hline 14 & 0.07 & 0.02 & 0.0014 \\
\hline Sum & 1.00 & & $\mathbf{0 . 1 0}$ \\
\hline
\end{tabular}

Thus for this lot

GW $=0.10$, or $10 \%$ 
CASE 2. Seedlot produced in production facility where pollen contamination exists

$$
\text { GW }=0.5 \sum\left[(1-P C) * B V M+P C * B V C+B_{i}\right]^{*} p_{i}
$$

where

$$
\begin{aligned}
& \mathrm{PC}=\text { proportion of contaminating pollen (see Appendix } 34 \text { for calculation methods) } \\
& \mathrm{BVM}=\text { average male } \mathrm{BV}, \text { weighted by genotypic contributions } \\
& \mathrm{BVC}=\mathrm{BV} \text { of contaminant pollen }
\end{aligned}
$$

[other variables as above]

If the contaminant pollen has a BV of 0 , this simplifies to

$$
\begin{aligned}
\mathrm{GW} & =0.5 \sum\left\{(1-\mathrm{PC}) * \mathrm{BVM}+\mathrm{BV}_{\mathrm{i}}\right\}^{*} \mathrm{p}_{\mathrm{i}} \\
& =0.5\left[(1-\mathrm{PC})^{*} \mathrm{BVM}+\sum\left(\mathrm{BV}_{\mathrm{i}}\right)^{*} \mathrm{p}_{\mathrm{i}}\right]
\end{aligned}
$$

Example 2: Breeding values and genotypic contributions as in Table 1.

$\mathrm{PC}=0.23$

BVC is assumed to be 0 .

Thus

$$
\begin{aligned}
\mathrm{GW} & =0.5 *[(1-0.23) * 0.1003+0.1003] \\
& =0.5 *[.0772+.1003] \\
& =0.09, \text { or } 9 \%
\end{aligned}
$$

CASE 3. Seedlot produced in production facility with pollen contamination and supplemental mass pollination (SMP)

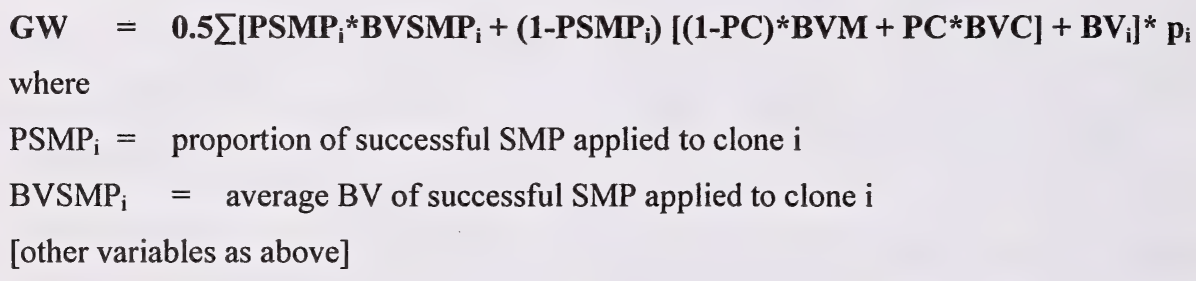

\section{REFERENCES}

Lambeth, C.C. 1980. Juvenile-mature correlations in Pinaceae and implications for early selection. For. Sci. 26: 571:580.

Woods, J.H., M.U. Stoehr and J.W. Webber. 1996. Protocols for rating seed orchard seedlots in British Columbia. BC Ministry of Forests, $26 \mathrm{p}$.

Xie, C.-Y. and A.D. Yanchuk. 2003. Breeding values of parental trees, genetic worth of seed orchard seedlots and yields of improved stocks in British Columbia. West. J. Appl. For. 18(2):88-100. 


\section{Appendix 32. Production Facility Establishment Report and Updates}

\section{See Standard 32.8.1.}

Establishment reports are due February 28 in the year following the establishment of the production facility. Establishment reports for seed facilities must contain the following information (for details, refer to sample establishment report on the Department's website). For vegetative production facilities, complete as appropriate. Contact the Department for information.

\section{Project Title}

\section{Location}

- Site name

- Legal land description

- Latitude and longitude

- Elevation

Site Information

- Physical description

- History of site use

\section{Parent Material Description}

- List of material comprising the orchard population

\section{Orchard Stock}

- Description of rearing regime

- Rootstock provenance

\section{Orchard Design}

- Design software used

- Constraints on spacing of related clones

\section{Planting Report}

- Planting date

- Planters' names

- Weather conditions

\section{Origin of Clones Table}

- Clone or family number

- Collection site

- Latitude and longitude

- Elevation

\section{Distribution of Clones}

- Listing of ramets per clone planted in the orchard keyed to planting year

- Ramets per clone in the clone bank

- Inventory of potted grafts per clone

\section{Planting Plan}

- List of grafts planted in the current year including clone and ramet number and planting position in the orchard 
- Showing all orchard positions with planted positions keyed to year of planting

\section{Site Layout Map}

- Showing position of orchard in relation to other plantations on site

\section{Access Map}

- Providing directions to the orchard

As changes occur (e.g. mortality, replacement, roguing), the above items should be updated and submitted to the Department annually as outlined in Appendix 35 (Production Facility Annual Operations Report). 


\section{Appendix 33. Permanent Sample Tree (PST) Protocols}

See Standard 32.8.2.

\section{PST System for Flowering and Seed Production Monitoring in Alberta Seed Orchards}

\section{PURPOSE}

- To provide orchard-specific local data for monitoring seed orchard development, flowering, cone and seed production, and seed quality, and

- To provide an estimate of reproductive contribution and a tool for cone crop forecasting.

\section{SAMPLE SIZE}

- For orchards with an intended maximum of up to 600 ramets (trees), the final number of PSTs designated is 60 .

- For orchards with an intended range of 600-2000 ramets (trees), the final number of PSTs designated is $10 \%$ of intended number of ramets (trees).

- For orchards with an intended maximum greater than 2000 ramets (trees), the final number of PSTs designated is 200 .

- In the case of clonal orchards, PSTs are added annually to proportionately represent each planting year.

- In clonal orchards, an attempt should be made to sample all clones represented by five or more ramets.

- PSTs should be well distributed across the orchard.

\section{DATA COLLECTED}

\section{All orchards}

- Height to the nearest $\mathrm{cm}$ to tip of terminal bud;

- Crown width at widest part of crown through one plane to nearest $\mathrm{cm}$;

- DBH to nearest $\mathrm{cm}$, once grafts reach breast height;

- Number of male and female flowers: actual count, or estimate if flowering is prolific;

- Number of cones (in the case of pine species, both mature and immature cones).

Developing orchards (pre-production)

Ripe cones are collected ( 5 cones per tree, where available) and bulked into a single PST collection for seed yield calculations and germination testing.

- Number of cones per litre;

- Number of seeds per cone;

- 1000 seed weight;

- Seed germination \%.

\section{Producing orchards}

The following traits may be assessed from operational cone collections; PST cones need not be collected separately.

- Number of cones per litre;

- Number of seeds per cone;

- 1000 seed weight;

- Seed germination \%.

\section{ASSESSMENT SCHEDULE}

Assessments are completed annually except for growth trait measurements, i.e. height, crown width and $\mathrm{DBH}$. These are done every second year. 


\section{DATA SUMMARIES}

Data are added annually to an electronic database maintained for each orchard. Data are to be summarized and reported in the Production Facility Annual Operations Report (Appendix 35) as illustrated in the following template tables.

Table 1. Template: Summary of Seed Production and Monitoring Information for Region Seed Orchard

Line Orchard Characteristics

Result

Line Immature Cone Production

Result

\begin{tabular}{|c|l|l|}
\hline 1 & Orchard design capacity & \\
\hline 2 & Total no. of seed trees established & \\
\hline 3 & Total no. of clones/families established & \\
\hline 4 & Average age & \\
\hline 5 & Age range & \\
\hline 6 & Average height $(\mathrm{cm} \pm$ SE) & \\
\hline 7 & Height range & \\
\hline 8 & Average crown width $(\mathrm{cm} \pm$ SE) & \\
\hline 9 & Crown width range & \\
\hline 10 & Average DBH $(\mathrm{cm} \pm$ SE) & \\
\hline 11 & DBH range & \\
\hline 12 & Total no. of PSTs & \\
\hline
\end{tabular}

Reproductive Balance

\begin{tabular}{|c|l|l|}
\hline 13 & No. of PSTs flowering & \\
\hline & Male Flowering & \\
\hline 14 & No. of PSTs with male flowers & \\
\hline 15 & Mean no. of male flowers/PST & \\
\hline 16 & Standard error of (line 13) & \\
\hline 17 & Range of male flowers/PST & \\
\hline & Female Flowering & \\
\hline 18 & No.of PSTs with female flowers & \\
\hline 19 & Mean no. of female flowers/PST & \\
\hline 20 & Standard error of (line 17) & \\
\hline 21 & Range female flowers/PST & \\
\hline 22 & Mean male-female flower production ratio & \\
\hline
\end{tabular}

\begin{tabular}{|l|l|l|}
\hline 23 & Date assessed & \\
\hline 24 & No. of PSTs producing cones & \\
\hline 25 & Mean no. of cones/PST & \\
\hline 26 & Standard error of (line 23) & \\
\hline 27 & Range of cones/PST & \\
\hline 28 & Cone crop estimate (\# of cones)* & \\
\hline 29 & Cone crop estimate (hectolitres) $)^{* *}$ & \\
\hline
\end{tabular}

Cone Production

\begin{tabular}{|l|l|l|}
\hline 30 & No. of PSTs producing cones & \\
\hline 31 & Mean no. of cones/PST & \\
\hline 32 & Range of cones/PST & \\
\hline 33 & $\begin{array}{l}\text { Total no. of cones collected from all PSTs } \\
\text { (max. 5/tree; developing orchards only) }\end{array}$ & \\
\hline 34 & Mean no. of cones/litre*** & \\
\hline
\end{tabular}

Seed Production***

\begin{tabular}{|l|l|l|}
\hline 35 & Seed production $(\mathrm{g})$ & \\
\hline 36 & No. of seeds/cone & \\
\hline 37 & 1000 seed weight & \\
\hline 38 & Germination \% & \\
\hline
\end{tabular}

* For all species except pine (line 2) $x$ (line 19)

* For pine species (line 2) $x$ (line 25)

** To estimate hectolitres divide (line 28 ) by the appropriate factor:

For white spruce $-15,000$ cones $/ \mathrm{hl}$

For black spruce $-24,000$ cones/hl

For lodgepole pine $-3,800$ cones $/ \mathrm{hl}$

*** For producing orchard, lines $34-38$ may be completed from operational crop data

Table 2. Template: Annual Mean Summary of PST Data for Region Seed Orchard

\begin{tabular}{|c|c|c|c|c|c|c|}
\hline Year & $\begin{array}{c}\text { Height } \\
(\mathrm{cm})\end{array}$ & $\begin{array}{c}\text { Crown Width } \\
(\mathrm{cm})\end{array}$ & Male Flowers & $\begin{array}{c}\text { Female } \\
\text { Flowers }\end{array}$ & $\begin{array}{c}\text { Immature } \\
\text { Cones }\end{array}$ & $\begin{array}{c}\text { Mature } \\
\text { Cones }\end{array}$ \\
\hline & & & & & & \\
& & & & & & \\
\hline
\end{tabular}




\section{Appendix 34. Pollen Contamination and Phenology Monitoring}

\section{See Standard 32.8.3.}

Note: These are interim guidelines only. A comprehensive reassessment of monitoring requirements should be undertaken when data have been collected.

\section{Part 1. Pollen contamination estimation}

Pollen differentiation by visual means is virtually impossible within genera. Thus white spruce pollen cannot be distinguished from black spruce pollen, nor lodgepole pine from jack pine, or aspen from balsam poplar. The table below will be used to determine pollen monitoring requirements in each orchard.

Monitoring is required as indicated.

\begin{tabular}{|c|l|l|l|l|}
\cline { 2 - 5 } \multicolumn{1}{c|}{} & \multicolumn{2}{c|}{ Orchard within breeding zone } & \multicolumn{2}{c|}{ Orchard outside breeding zone } \\
\hline Gain requested? & \multicolumn{2}{|c|}{ Pollen distinguishable? } & \multicolumn{1}{c|}{ no } & \multicolumn{1}{c|}{ yes } \\
\hline yes & $\begin{array}{l}\text { monitoring distinguishable? } \\
\text { required }\end{array}$ & $\begin{array}{l}\text { monitoring not } \\
\text { required; see 2 } \\
\text { below }\end{array}$ & $\begin{array}{l}\text { monitoring } \\
\text { required }\end{array}$ & $\begin{array}{l}\text { monitoring not } \\
\text { required; see 1 and } \\
\text { 2 below }\end{array}$ \\
\hline no & $\begin{array}{l}\text { monitoring not } \\
\text { required }\end{array}$ & $\begin{array}{l}\text { monitoring not } \\
\text { required }\end{array}$ & $\begin{array}{l}\text { monitoring } \\
\text { required }\end{array}$ & $\begin{array}{l}\text { monitoring not } \\
\text { required; see 1 } \\
\text { below }\end{array}$ \\
\hline
\end{tabular}

1. orchard manager must demonstrate to the Department's satisfaction that pollen contamination will not significantly compromise the adaptation of seed produced

2. orchard manager must demonstrate to the Department's satisfaction how pollen contamination will be factored into gain requests

Pollen contamination can reduce the genetic worth of a seedlot or in extreme cases render a seedlot maladapted. Pollen monitoring will be used where required to estimate contamination levels.

\section{GUIDELINES}

- The orchard manager will monitor pollen flight within each orchard at a minimum of two locations, and preferably four.

- The orchard manager will monitor pollen flight outside the orchard at a minimum of two regional monitors for each orchard complex. Regional monitors may be established within orchards that have not yet begun to produce pollen.

- Regional monitors should ideally be located in an open area, a minimum of $300 \mathrm{~m}$ from the orchard boundary and not downwind from the orchard.

- The type of pollen monitoring device used is the responsibility of the orchard manager but the manager must ensure that daily pollen cloud density values can be reliably generated.

- Traps should be changed at least every two days, and every day during periods of peak flight.

- Pollen counts will be expressed as grains per square mm over the change interval (generally 24 hours to 48 hours), averaged over directions if directional monitors are used, and summed over the monitoring period. Total counts will then be averaged over all monitors of each category (regional or within-orchard).

- All traps should be erected and counts begun several days before pollen flight locally or in the orchard is expected to begin, and should be continued until the orchard is no longer receptive (see Part 2. Phenology monitoring).

- For pine orchards, within-orchard monitors should be located at a height of one-half of the average crown height of the orchard. 
- For spruce orchards, within-orchard monitors should be located at a height of threequarters of the average crown height of the orchard.

\section{ESTIMATION OF CONTAMINATION LEVELS}

THIS SECTION UNDER REVIEW - In the interim, contamination levels used for genetic worth calculations will be determined on a case by case basis.

Since it is impossible to differentiate visually between pollen produced within an orchard and pollen of the same species originating outside the orchard, the amount of foreign pollen cannot be estimated directly. Instead, a surrogate species or genus with recognizably distinct pollen can be used to provide an estimate of the proportion of outside pollen that penetrates into an orchard (e.g. for a pine orchard, tamarack or spruce can be used as a surrogate).

The external (outside-orchard) pollen levels of the surrogate species and target species (xs and xt, respectively) are estimated by the orchard manager using regional monitors. The within-orchard pollen levels of the surrogate and target species (ws and wt, respectively) are measured using orchard monitors.

The ratio of pollen density within the orchard to pollen density outside the orchard, in the open, can then be calculated for the surrogate species. This ratio is assumed to be independent of time, so that the surrogate need not be flowering simultaneously with the target species. It is assumed that the proportion of target species pollen penetrating the orchard from outside will be the same as the proportion of surrogate species pollen penetrating from outside. Thus this ratio also reflects the ratio of within-orchard to outsideorchard levels of non-orchard or contaminating, target species pollen. This ratio is expected to be considerably less than 1 for a mature orchard, due to altered wind speed and patterns, and the screening effect of the orchard trees.

Thus the contaminant pollen level for the target species, ct, within the orchard can be estimated as

$$
\text { ct }=\mathbf{w s} / \mathbf{x s}(\mathbf{x t})
$$

and the proportion of contaminant pollen, pc, within the orchard can be estimated as

$$
\begin{aligned}
p c & =c t / w t \\
& =\left(w s^{*} x t\right) /\left(x s^{*} w t\right)
\end{aligned}
$$

where

ct $=$ contaminant pollen level of target species

ws $=$ within-orchard pollen level of surrogate species

$\mathrm{xs}=$ outside orchard pollen level of surrogate species

$\mathrm{xt}=$ outside orchard pollen level of target species

wt $=$ within-orchard pollen level of target species

$\mathrm{pc}=$ proportion of contaminant pollen (within-orchard target species pollen that originated outside the orchard)

This number, pc, is used in the calculation of genetic worth of orchard seedlots (see Appendix 31).

\section{EXAMPLE}

A pine orchard has been established in an area where spruce pollen is present in significant amounts; thus spruce can be used as the surrogate species. There are two regional monitors, R1 and R2, and three withinorchard monitors, $\mathrm{O} 1-\mathrm{O} 3$. Counts for both species are shown in the table below. They were taken from directional monitors and averaged over directions. 
Pollen counts (grains $/ \mathrm{mm}^{2}$ ) from orchard pollen monitors, averaged over directions

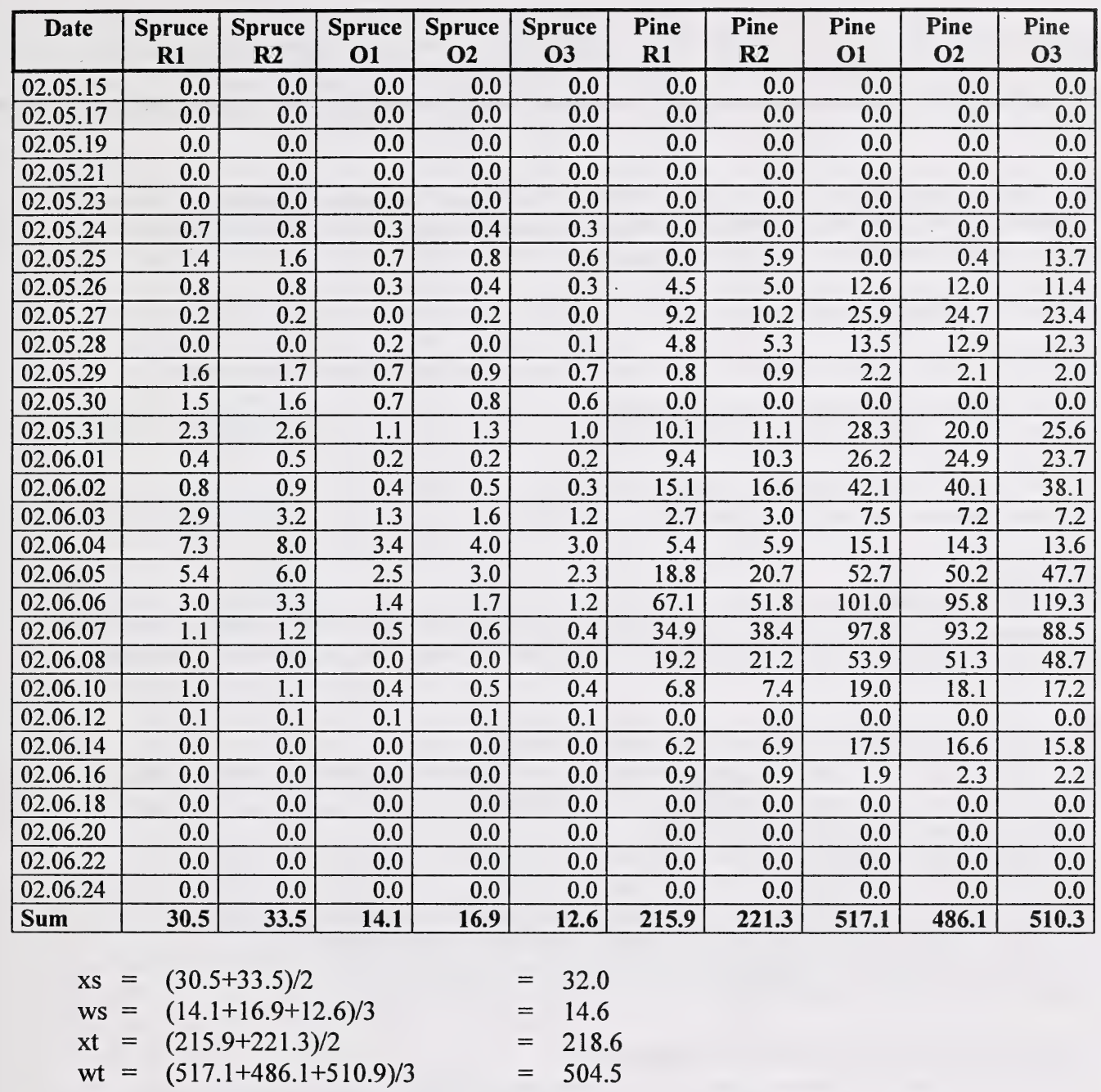

Thus the pollen contamination for this pine orchard in 2002 is estimated at

$$
\text { pc }=\left(w^{*} x t\right) /\left(x s^{*} w t\right) \quad=0.20
$$




\section{Part 2. Phenology monitoring}

Phenology monitoring allows the orchard manager to identify clones that are receptive either later or earlier than the bulk of the orchard population. Together with pollen monitoring, it also allows the manager to relate patterns of within-orchard pollen flight to periods of orchard receptivity, and to identify clones that may not be successfully pollinated.

It is believed that periods of pollen flight of local and contaminating pollen are coincident in Alberta seed orchards. Monitoring the phenology of orchard trees and relating it to pollen flow within and outside the orchard will provide an empirical test of this assumption.

Phenology monitoring is required as follows:

- Prior to full orchard establishment: in any year in which a collectible crop is anticipated;

- Following full orchard establishment: a minimum of five years of data will be collected during years in which a collectible crop is anticipated;

- For new clones introduced into an existing orchard: five years of data will be collected together with data from ten previously monitored clones, to allow comparison.

\section{SAMPLING LEVEL}

Permanent Sample Trees (PSTs) may be used for phenology monitoring. At least one ramet of each clone represented in the PST population will be monitored from approximately stage 3 (see below) until stage 7 , at intervals of two days or less.

White spruce female bud and reproductive phenology

\begin{tabular}{|c|l|}
\hline Stage & \multicolumn{1}{c|}{ Female Bud Description } \\
\hline 1 & dormant bud - bud scales dry; no swelling \\
\hline 2 & early bud swell - pointed tip, scales shiny, resinous, dark brown \\
\hline 3 & late bud swell - bud elongates, becomes oblong; identifiable \\
\hline 4 & early flushing - ovuliferous scales (o.s.) visible through bud scales; bud scales partially rip off \\
\hline 5 & advanced flushing - cone becoming erect, some o.s. at central portion separate \\
\hline 6 & fully receptive - cone erect, o.s. separate and bend perpendicular to cone axis \\
\hline 7 & post-receptive - cone scales closing \\
\hline
\end{tabular}

Lodgepole pine female reproductive phenology

\begin{tabular}{|c|c|}
\hline Stage & Female Bud Description \\
\hline 1 & seed cone still fully contained within shoot bud scales \\
\hline 2 & seed cone bud still contained within flower bud scales \\
\hline 3 & seed cone starting to emerge; rosette of cone scales just visible; not receptive \\
\hline 4 & seed cone emerging; some pollen may reach ovules; \\
\hline 5 & $\begin{array}{l}\text { advanced flushing seed cone emerged but not fully open; cone axis not elongated; pollen may } \\
\text { reach ovules }\end{array}$ \\
\hline 6 & $\begin{array}{l}\text { fully receptive - seed cone emerged and spaces between scales allow pollen to sift down to the } \\
\text { ovules }\end{array}$ \\
\hline 7 & post-receptive- cone scales thickened, preventing pollen entry \\
\hline
\end{tabular}

- A clone is considered receptive when $20 \%$ of the cones are fully receptive (stage 6).

- A clone is considered to have completed receptivity when $80 \%$ of the cones are post-receptive (stage 7).

- The orchard is considered receptive when $20 \%$ of clones are receptive, and to have completed receptivity when $80 \%$ of clones are unreceptive. 


\section{REFERENCES}

Owens, J.N. 1984. The reproductive cycle of lodgepole pine. BC Ministry of Forests. 29p.

Owens, J.N. and M. Molder. 1984. The reproductive cycle of interior spruce. BC Ministry of Forests. $31 \mathrm{p}$. 


\section{Appendix 35. Production Facility Annual Operations Report}

See Standard 32.8.4.

Annual operations reports are due February 28 in the year following the year in which the operations took place. Annual operations reports for seed facilities must contain the following information (for details, refer to the sample report located on the Department's website). For vegetative production facilities, complete as appropriate. Contact the Department for information.

\section{Name of the Relevant CPP Plan}

\section{Orchard Description}

- Name, number, location

- Manager

- Area occupied (ha)

- Design capacity (\# clones, parents, trees)

- Number of grafts established

Cultural Activities

- Irrigation

- Fertilization

- Vegetation management (mowing, herbicide applications, etc.)

- Crown management (topping, lower branch pruning)

- Flower induction

- Supplemental pollination

\section{Insect and Disease Incidence}

- Monitoring methods

- Control measures

\section{Other Activities}

- Activities that may not occur annually but have an impact on orchard composition, e.g. roguing, thinning

\section{Orchard Monitoring}

- $\quad$ PST report (see Appendix 33)

- Pollen density and phenology of orchard receptivity (see Appendix 34)

\section{Cone and Seed Production}

- Timing and method of cone collection

- Total cone production (hectoliters)

- Total seed production (grams)

- 1000 seed weight

- Germination \%

- Effective population size (see Appendix 36)

\section{Subsequent Years' Planning}

- Report on items that may affect registration of crops or licensing of faciltities 
- Report on planting including:

- List of grafts planted in the current year including clone, ramet number and planting position in the orchard

- Planters

- Planting date

- Planting conditions (Wx, soil moisture etc.)

- Report on mortality including:

- Listing of grafts (clone and ramet) which died in the previous winter and over the past growing season along with its orchard position

- Known or suspected causes of graft mortality

- Report on distribution of clones including:

- Listing of all ramets per clone planted in the orchard keyed to planting year

- Percent of total orchard capacity planted

- Ramets per clone in the clone bank

- Inventory of potted grafts per clone

- A current orchard layout map showing all orchard positions keyed to design clone and with all current planted positions showing clone and ramet number keyed to year of planting 


\title{
Appendix 36. Calculation of Effective Population Size ( $\mathrm{Ne}$ ) for Vegetative Lots and Orchard Seedlots
}

\author{
See Standards 33.4, 33.6, 34.3, 34.3.1, 34.5.
}

\section{INTRODUCTION}

Calculation methods presented here for effective population size of seed or vegetative lots produced by unrelated, non-inbred genotypes are based on the work of Robertson (1961) and developed in Kang and Namkoong (1988); formulae developed elsewhere may give very different results.

Calculation methods for effective population size of seed or vegetative lots produced by orchards or stoolbeds containing inbred or related genotypes, such as half-sib seedling orchards, involve coancestry values, and are based on the work of Lindgren and Mullin (1998), who generalized earlier work.

\section{FORMULAE}

Effective population size of a seed or vegetative lot can be calculated as

$$
N e=0.5 /\left(\Sigma \Sigma \mathrm{p}_{\mathrm{i}} \mathrm{p}_{\mathrm{j}} \mathrm{c}_{\mathrm{ij}}\right) \quad(\mathrm{i}, \mathrm{j}=1,2, \ldots, \mathrm{n})
$$

or, in matrix notation

$$
\mathrm{Ne}=0.5 / \mathbf{p}^{\prime} \mathrm{Cp}
$$

where

$$
\begin{aligned}
& N e=\text { effective population size } \\
& \mathrm{p}_{\mathrm{i}}=\text { the proportional genetic contribution of clone or genotype } \mathrm{i} \\
& \mathrm{p}_{\mathrm{j}}=\text { the proportional genetic contribution of genotype } \mathrm{j} \\
& \mathrm{c}_{\mathrm{ij}}=\text { coancestry between genotypes } \mathrm{i} \text { and } \mathrm{j} \\
& \mathrm{n}=\text { number of genotypes } \\
& \mathbf{p}=\text { the } \mathrm{n} \times 1 \text { vector of gametic proportions for genotypes } \mathrm{i}=1,2, \ldots, \mathrm{n} \\
& \mathbf{C}=\text { the } \mathrm{n} \times \mathrm{n} \text { coancestry matrix for genotypes } \mathrm{i}=1,2, \ldots, \mathrm{n}
\end{aligned}
$$

The proportional genetic contribution, $\mathrm{p}_{\mathrm{i}}$, of genotype $\mathrm{i}$ is calculated as follows:

$$
\begin{array}{ll}
\mathrm{p}_{\mathrm{i}}=\mathrm{f}_{\mathrm{i}} / \Sigma \mathrm{f}_{\mathrm{i}} & \text { for proportions based only on samples of female "flower" or cone counts } \\
\mathrm{p}_{\mathrm{i}}=\left(\mathrm{f}_{\mathrm{i}} / \Sigma \mathrm{f}_{\mathrm{i}}+\mathrm{m}_{\mathrm{i}} / \Sigma \mathrm{m}_{\mathrm{i}}\right) / 2 & \text { for proportions based on samples of both female and male "flower" counts } \\
\mathrm{p}_{\mathrm{i}}=\mathrm{n}_{\mathrm{i}} / \Sigma \mathrm{n}_{\mathrm{i}} & \text { for proportions based on total counts of cuttings per clone }
\end{array}
$$

where

$\mathrm{f}_{\mathrm{i}}=$ the number of female "flowers" occurring on genotype $\mathrm{i}$ (alternatively, cone counts can be used)

$\mathrm{m}_{\mathrm{i}}=$ the number of male "flowers" occurring on genotype $\mathrm{i}$

$\mathrm{n}_{\mathrm{i}}=$ the number of cuttings taken from genotype $\mathrm{i}$

Where genotypes are unrelated and not inbred, formula (1) simplifies to

$$
\mathrm{Ne}=1 / \Sigma \mathrm{p}_{\mathrm{i}}^{2}
$$




\section{COANCESTRIES}

Coancestry values for some common relationships between non-inbred individuals are shown below.

\section{Common coancestry values}

\begin{tabular}{|l|r|}
\hline Relationship between genotypes & Coancestry \\
\hline Identical (tree with itself or with ramet of the same clone) & 0.500 \\
\hline Full-sib (two individuals with same mother and father) & 0.250 \\
\hline Parent-offspring (individual with mother or with father) & 0.250 \\
\hline $\begin{array}{l}\text { Half-sib (two individuals with same mother or father but not } \\
\text { both; e.g. members of open-pollinated family) }\end{array}$ & 0.125 \\
\hline Unrelated individuals & 0.000 \\
\hline
\end{tabular}

\section{CATEGORIES AND CALCULATIONS}

Four types of production facility are addressed, with a worked example for each.

A. Vegetative production facilities

1. stoolbeds producing vegetative lots of unrelated clones

2. stoolbeds producing vegetative lots of related clones (amplified full-sib or half-sib families)

B. Seed orchards including monoecious and dioecious species

1. orchards of unrelated and non-inbred genotypes (e.g. most first generation clonal orchards, including potted orchards)

2. orchards of related, non-inbred genotypes (e.g. open-pollinated seedling seed orchards and advanced generation clonal orchards with related clones)

No example is included of a facility including inbred genotypes, since no such facilities are expected in Alberta in the near future. However, such calculations would use equations (1) or (2) with no additional modification.

All calculations for the first and third categories can be done easily in EXCEL, using equation (3).

Calculations for most lots from facilities in categories 2 and 4 can be done by means of matrix manipulation using equation (2), in EXCEL; the coancestry matrix need only be constructed once for each facility, and frequency vector $\mathbf{p}$ reconstructed for each annual crop. For production facilities including a very large number of genotypes (e.g. seedling seed orchards), SAS or the ACCESS program noted below can be used.

An ACCESS program developed for calculation of $\mathrm{Ne}$ for orchards including related genotypes using equation (1) was developed by Weyerhaeuser Company, in collaboration with the BC Ministry of Forests; this program is available through the Forest Genetics Program, Alberta Sustainable Resource Development, Edmonton. The contributions of BC Ministry of Forests geneticist Michael Stoehr are gratefully acknowledged. 


\section{A. VEGETATIVE MATERIAL}

Note: $\mathrm{Ne}$ calculations for vegetatively reproduced material are based on actual total numbers in a vegetative lot, not on a sample, as for seed orchards.

\section{A.1 Vegetative lots of unrelated clones}

EXAMPLE 1: A vegetative lot containing 2360 individuals of 10 unrelated clones

\begin{tabular}{|c|r|r|r|}
\hline Clone & $\begin{array}{c}\text { Number of } \\
\text { cuttings or } \\
\text { plants }\end{array}$ & \multicolumn{1}{|c|}{$\mathbf{p}_{\mathbf{i}}$} & $\mathbf{p}_{\mathbf{i}}{ }^{2}$ \\
\hline 1 & 300 & 0.127 & 0.01616 \\
\hline 2 & 10 & 0.004 & 0.00002 \\
\hline 3 & 150 & 0.064 & 0.00404 \\
\hline 4 & 240 & 0.102 & 0.01034 \\
\hline 5 & 460 & 0.195 & 0.03799 \\
\hline 6 & 300 & 0.127 & 0.01616 \\
\hline 7 & 190 & 0.081 & 0.00648 \\
\hline 8 & 200 & 0.085 & 0.00718 \\
\hline 9 & 240 & 0.102 & 0.01034 \\
\hline 10 & 270 & 0.114 & 0.01309 \\
\hline Total & $\mathbf{2 3 6 0}$ & & $\mathbf{0 . 1 2 1 8 0}$ \\
\hline
\end{tabular}

Using equation (3)

$$
\begin{aligned}
N e & =1 / \Sigma \mathrm{p}_{\mathrm{i}}^{2} \\
& =1 / 0.1218=8.21
\end{aligned}
$$

\section{A.2. Vegetative lots of related clones (amplified full-sib or half-sib families)}

This example is worked manually to show the application of equation (1), as well as in matrix notation using equation (2). Calculations for actual vegetative lots would normally be done using matrices in EXCEL or SAS, or by using the ACCESS program available from the Department.

EXAMPLE 2: A vegetative lot containing five clones, with two clones belonging to one full-sib family, and three belonging to a second half-sib family, unrelated to the first family

Coancestry table (showing $c_{i j}$ for each pair of clones $\mathbf{i}$ and $\mathbf{j}$ )

\begin{tabular}{|c|c|c|c|c|c|c|}
\cline { 3 - 7 } \multicolumn{2}{c|}{} & \multicolumn{2}{c|}{ Family 1 } & \multicolumn{3}{c|}{ Family 2 } \\
\cline { 2 - 7 } \multicolumn{2}{c|}{} & Clone 1 & $\mathbf{2}$ & $\mathbf{3}$ & $\mathbf{4}$ & $\mathbf{5}$ \\
\hline Family 1 & Clone 1 & 0.5 & 0.25 & 0 & 0 & 0 \\
\hline & $\mathbf{2}$ & 0.25 & 0.5 & 0 & 0 & 0 \\
\hline Family 2 & $\mathbf{3}$ & 0 & 0 & 0.5 & 0.125 & 0.125 \\
\hline & $\mathbf{4}$ & 0 & 0 & 0.125 & 0.5 & 0.125 \\
\hline & $\mathbf{5}$ & 0 & 0 & 0.125 & 0.125 & 0.5 \\
\hline
\end{tabular}




\begin{tabular}{|l|l|r|r|}
\hline Family & Clone & $\begin{array}{c}\text { Number of cuttings } \\
\text { or plants }\end{array}$ & \multicolumn{1}{c|}{$\mathbf{p}_{\mathbf{i}}$} \\
\hline 1 & 1 & 910 & 0.13 \\
\hline 1 & 2 & 1960 & 0.28 \\
\hline 2 & 3 & 2870 & 0.41 \\
\hline 2 & 4 & 1050 & 0.15 \\
\hline 2 & 5 & 210 & 0.03 \\
\hline Total & & $\mathbf{7 0 0 0}$ & \\
\hline
\end{tabular}

Construct a weighted table where $x_{i j}=p_{i} p_{j} c_{i j}$

\begin{tabular}{|c|c|r|r|r|r|r|}
\cline { 3 - 7 } \multicolumn{2}{c|}{} & \multicolumn{2}{c|}{ Family 1 } & \multicolumn{3}{c|}{ Family 2 } \\
\cline { 3 - 7 } \multicolumn{2}{c|}{} & \multicolumn{1}{c|}{ Clone 1 } & \multicolumn{1}{c|}{$\mathbf{2}$} & $\mathbf{3}$ & $\mathbf{4}$ & $\mathbf{5}$ \\
\hline Family 1 & Clone 1 & 0.00845 & 0.0091 & 0 & 0 & 0 \\
\hline & $\mathbf{2}$ & 0.0091 & 0.0392 & 0 & 0 & 0 \\
\hline Family 2 & $\mathbf{3}$ & 0 & 0 & 0.08405 & 0.007688 & 0.001538 \\
\hline & $\mathbf{4}$ & 0 & 0 & 0.007688 & 0.01125 & 0.000562 \\
\hline & $\mathbf{5}$ & 0 & 0 & 0.001538 & 0.000562 & 0.00045 \\
\hline
\end{tabular}

summing over terms:

$$
\Sigma \Sigma \mathrm{p}_{\mathrm{i}} \mathrm{p}_{\mathrm{j}} \mathrm{c}_{\mathrm{ij}}=0.181175
$$

and using equation (1)

$$
N e=0.5 /\left(\Sigma \Sigma \mathrm{p}_{\mathrm{i}} \mathrm{p}_{\mathrm{j}} \mathrm{c}_{\mathrm{ij}}\right)=2.76
$$

\section{EXAMPLE 2 reworked using matrices}

$$
\mathbf{p}=\left[\begin{array}{l}
0.13 \\
0.28 \\
0.41 \\
0.15 \\
0.03
\end{array}\right] \quad \mathbf{C}=\left[\begin{array}{rrrrr}
0.5 & 0.25 & 0 & 0 & 0 \\
0.25 & 0.5 & 0 & 0 & 0 \\
0 & 0 & 0.5 & 0.125 & 0.125 \\
0 & 0 & 0.125 & 0.5 & 0.125 \\
0 & 0 & 0.125 & 0.125 & 0.5
\end{array}\right]
$$

$\mathbf{p}^{\prime} \mathbf{C p}=0.181175$

and using equation (2)

$\mathrm{Ne}=0.5 / \mathbf{p}^{\prime} \mathbf{C p}=2.76$, as above. 


\section{B. SEED ORCHARD CROPS}

(See Appendix 37 for sampling levels required for Ne determination.)

B.1. Seedlots from orchards of unrelated and non-inbred genotypes (e.g. most first generation clonal orchards)

The value of $p_{i}$ may be calculated using only the female component, i.e. estimates of flower or cone numbers, or using both male and female components, with estimates of pollen cone numbers in addition to estimates of seed cone numbers. In this example we demonstrate both methods.

EXAMPLE 3: A clonal orchard with a total of 50 ramets of 10 clones

Count of female and male "flowers" for each ramet

\begin{tabular}{|c|c|r|r|}
\hline Clone & Ramet & Females & Males \\
\hline $\mathrm{x} 123$ & 1 & 50 & 500 \\
\hline $\mathrm{x} 123$ & 2 & 50 & 600 \\
\hline $\mathrm{x} 123$ & 3 & 0 & 100 \\
\hline $\mathrm{x} 123$ & 4 & 75 & 660 \\
\hline $\mathrm{x} 123$ & 5 & 85 & 1000 \\
\hline $\mathrm{x} 123$ & 6 & 80 & 450 \\
\hline $\mathrm{x} 123$ & 7 & 0 & 120 \\
\hline $\mathrm{x} 123$ & 8 & 230 & 1860 \\
\hline $\mathrm{x} 354$ & 1 & 0 & 20 \\
\hline $\mathrm{x} 354$ & 2 & 0 & 0 \\
\hline $\mathrm{x} 354$ & 3 & 25 & 300 \\
\hline $\mathrm{x} 354$ & 4 & 0 & 50 \\
\hline $\mathrm{x} 354$ & 5 & 0 & 0 \\
\hline $\mathrm{x} 465$ & 1 & 50 & 430 \\
\hline $\mathrm{x} 465$ & 2 & 350 & 1980 \\
\hline $\mathrm{x} 466$ & 1 & 225 & 2100 \\
\hline $\mathrm{x} 466$ & 2 & 125 & 1490 \\
\hline $\mathrm{x} 466$ & 3 & 425 & 3580 \\
\hline $\mathrm{x} 466$ & 4 & 0 & 0 \\
\hline $\mathrm{x} 466$ & 5 & 900 & 7500 \\
\hline $\mathrm{x} 466$ & 6 & 100 & 900 \\
\hline $\mathrm{x} 466$ & 7 & 1450 & 9800 \\
\hline $\mathrm{x} 466$ & 8 & 85 & 400 \\
\hline $\mathrm{x} 487$ & 1 & 0 & 50 \\
\hline $\mathrm{x} 487$ & 2 & 20 & 200 \\
\hline $\mathrm{x} 487$ & 3 & 125 & 980 \\
\hline & & & \\
\hline
\end{tabular}

\begin{tabular}{|c|c|c|c|}
\hline Clone & Ramet & Females & Males \\
\hline$\times 487$ & $\overline{4}$ & 75 & 640 \\
\hline $\mathrm{x} 699$ & 1 & 475 & 3200 \\
\hline $\mathrm{x} 699$ & 2 & 575 & 6000 \\
\hline $\mathrm{x} 699$ & 3 & 275 & 1300 \\
\hline$\times 699$ & 4 & 375 & 2900 \\
\hline x699 & 5 & 0 & 50 \\
\hline $\mathrm{x} 732$ & 1 & 0 & 170 \\
\hline$x 732$ & 2 & 0 & 50 \\
\hline $\mathrm{x} 732$ & 3 & 0 & 60 \\
\hline $\mathrm{x} 732$ & 4 & 60 & 590 \\
\hline $\mathrm{x} 732$ & 5 & 0 & 0 \\
\hline$x 732$ & 6 & 80 & 680 \\
\hline$x 744$ & 1 & 50 & 370 \\
\hline$x 744$ & 2 & 0 & 210 \\
\hline $\mathrm{x} 744$ & 3 & 35 & 250 \\
\hline$x 744$ & 4 & 175 & 1500 \\
\hline$\times 798$ & 1 & 225 & 1900 \\
\hline$\times 798$ & 2 & 30 & 290 \\
\hline $\mathrm{x} 798$ & 3 & 450 & 5400 \\
\hline x798 & 4 & 0 & 60 \\
\hline $\mathrm{x} 798$ & 5 & 75 & 650 \\
\hline x900 & 1 & 80 & 870 \\
\hline $\mathrm{x} 900$ & 2 & 0 & 50 \\
\hline $\mathrm{x} 900$ & 3 & 0 & 110 \\
\hline
\end{tabular}


Summarize by clone and calculate proportions:

- for proportions based only on female counts: $p_{i}=f_{i} / \Sigma f_{i}$

- for proportions based on both female and male counts: $p_{i}=\left(f_{i} / \Sigma f_{i}+m_{i} / \Sigma m_{i}\right) / 2$

\begin{tabular}{|c|c|c|c|c|c|c|c|c|}
\hline Clone & Ramets & $\begin{array}{c}\text { Females } \\
\left(\mathbf{f}_{\mathbf{i}}\right)\end{array}$ & $\begin{array}{c}\text { Males } \\
\left(m_{i}\right)\end{array}$ & $\begin{array}{c}\mathbf{p}_{\mathrm{i}} \\
\text { (f only) }\end{array}$ & $\begin{array}{c}p_{i}{ }^{2} \\
\text { (f only) }\end{array}$ & $\begin{array}{c}\mathbf{p}_{\mathrm{i}} \\
\text { (m only) }\end{array}$ & $\begin{array}{c}\mathbf{p}_{\mathbf{i}} \\
(\mathbf{m} \& \mathbf{f})\end{array}$ & $\begin{array}{c}p_{i}{ }^{2} \\
(m \& \& f)\end{array}$ \\
\hline $\mathrm{x} 123$ & 8 & 570 & 5290 & 0.076 & 0.006 & 0.085 & 0.080 & 0.006 \\
\hline$\times 354$ & 5 & 25 & 370 & 0.003 & 0.000 & 0.006 & 0.005 & 0.000 \\
\hline$\times 465$ & 2 & 400 & 2410 & 0.053 & 0.003 & 0.039 & 0.046 & 0.002 \\
\hline $\mathrm{x} 466$ & 8 & 3310 & 25770 & 0.442 & 0.196 & 0.413 & 0.428 & 0.183 \\
\hline $\mathrm{x} 487$ & 4 & 220 & 1870 & 0.029 & 0.001 & 0.030 & 0.030 & 0.001 \\
\hline$\times 699$ & 5 & 1700 & 13450 & 0.227 & 0.052 & 0.216 & 0.221 & 0.049 \\
\hline $\mathrm{x} 732$ & 6 & 140 & 1550 & 0.019 & 0.000 & 0.025 & 0.022 & 0.000 \\
\hline $\mathrm{x} 744$ & 4 & 260 & 2330 & 0.035 & 0.001 & 0.037 & 0.036 & 0.001 \\
\hline $\mathrm{x} 798$ & 5 & 780 & 8300 & 0.104 & 0.011 & 0.133 & 0.119 & 0.014 \\
\hline x900 & 3 & 80 & 1030 & 0.011 & 0.000 & 0.017 & 0.014 & 0.000 \\
\hline Total & 50 & 7485 & 62370 & 1.00 & 0.270 & 1.00 & 1.00 & 0.256 \\
\hline \multicolumn{2}{|c|}{$\mathrm{Ne}=1 / \Sigma\left(\mathrm{p}_{\mathrm{i}}{ }^{2}\right)$} & & & & 3.70400 & & & 3.906 \\
\hline
\end{tabular}

In this example, $\mathrm{Ne}$ based only on female counts $=3.7$, while including male counts increases the estimate of $\mathrm{Ne}$ to 3.91. Including male counts will increase the accuracy of $\mathrm{Ne}$ estimates, but may result in either increased or decreased $\mathrm{Ne}$ estimates. Note that $\mathrm{Ne}$ is considerably less than the number of clones (10). This is due to imbalance in both numbers of ramets/clone and in reproductive activity.

B.2. Seedlots from orchards of related, non-inbred genotypes (e.g. open-pollinated seedling seed orchards and advanced generation clonal orchards with related clones)

EXAMPLE 4: a half-sib seedling orchard containing two families with three and two individuals respectively

$\mathbf{p}=\left[\begin{array}{l}0.24 \\ 0.32 \\ 0.09 \\ 0.20 \\ 0.15\end{array}\right] \quad \mathbf{C}=\left[\begin{array}{rrrrr}0.5 & 0.125 & 0.125 & 0 & 0 \\ 0.125 & 0.5 & 0.125 & 0 & 0 \\ 0.125 & 0.125 & 0.5 & 0 & 0 \\ 0 & 0 & 0 & 0.5 & 0.125 \\ 0 & 0 & 0 & 0.125 & 0.5\end{array}\right]$

$\mathbf{p}^{\prime} \mathbf{C p}=0.1546$

and using equation (2)

$\mathrm{Ne} \quad=0.5 / \mathbf{p}^{\prime} \mathrm{Cp}=3.23$.

\section{REFERENCES}

Kang, H. and G. Namkoong. 1988. Inbreeding effective population size under some artificial selection schemes. 1. Linear distribution of breeding values. Theor. Appl. Genet. 75:333-339.

Lindgren, D. and T. Mullin. 1998. Relatedness and status number in seed orchard crops. Can. J. For. Res. 28: 276-283.

Robertson, A. 1961. Inbreeding in artificial selection programmes. Genet. Res. 2:189-194.

Woods, J.H., M.U. Stoehr and J.W. Webber. 1996. Protocols for rating seed orchard seedlots in British Columbia. BC Ministry of Forests, $26 \mathrm{p}$. 


\section{Appendix 37. Sampling Levels for Calculation of $\mathrm{Ne}$ Values in Orchard Seedlots}

\section{See Standards 33.4 and 33.4.1.}

Note: These are interim guidelines only. A comprehensive reassessment of sampling requirements should be undertaken once five years of data have been collected. Available data to be reviewed for adequacy prior to standards five-year review.

\section{INTRODUCTION}

Effective population size (see Appendix 36 for calculation methods) is used as a surrogate for genetic diversity levels in seed and vegetative lots, and also reflects the degree of imbalance among genotypes contributing to a given lot. While genotypic representation in vegetative lots can be readily determined directly, in seed lots this is impossible, and an approximation must be made.

The orchard manager should be aware that $\mathrm{Ne}$ estimates will vary with the intensity of sampling. These estimates may be considerably lower than, or in some cases higher than, the actual $\mathrm{Ne}$. Estimates based on assessment of only female flowers or cones will be less accurate than those including information from male flowers and reproductive phenology. Since the purpose of $\mathrm{Ne}$ estimation is to ensure that a threshold has been met, rather than to determine the actual value of $\mathrm{Ne}$, the required intensity of sampling is higher where smaller numbers of genotypes contribute.

Simulations with actual orchard data showed that an orchard sample of $10 \%$ (as in PSTs) can yield an $\mathrm{Ne}$ estimate as low as one-fifth of the $\mathrm{Ne}$ calculated on a $100 \%$ orchard survey. On average, the ratio of the $\mathrm{Ne}$ estimate obtained with $10 \%$ sampling to the $\mathrm{Ne}$ estimate at $100 \%$ sampling $[\mathrm{Ne}(10 \%) / \mathrm{Ne}(100 \%)]$ is expected to be approximately 0.5 , depending on the distribution of genotypic frequencies. At a $50 \%$ sampling intensity, the average $\mathrm{Ne}(50 \%) / \mathrm{Ne}(100 \%)$ ratio increased to approximately 0.9 , but may, by chance, be below 0.7 . Thus minimum requirements outlined below may not be adequate to demonstrate that $\mathrm{Ne}$ thresholds have been exceeded. It is the responsibility of the orchard manager to demonstrate, through estimates of gametic contribution, that the minimum required $\mathrm{Ne}$ has been achieved.

\section{CLONAL SEED ORCHARDS}

Table 1 below outlines minimum sampling requirements for clonal seed orchards.

Table 1. Sampling requirements for Ne calculations in clonal seed orchards

\begin{tabular}{|c|c|c|}
\hline Clones contributing & Minimum sampling requirement & Genders assessed $^{* *}$ \\
\hline $100+$ & PSTs only* & Female \\
\hline \multirow{2}{*}{$75-99$} & $15 \%$ including PSTs & male \& female \\
\hline \multirow{2}{*}{$50-74$} & Alternative: $100 \%$ & Female \\
\hline $25-49$ & $25 \%$ including PSTs & male \& female \\
\hline$<25$ & Alternative: $100 \%$ & Female \\
\cline { 2 - 3 } & $50 \%$ including PSTs & male \& female \\
\hline & $100 \%$ - (all trees) & male \& female \\
\hline
\end{tabular}

*PSTs are expected to include at least $10 \%$ of orchard trees, to a maximum of 200 PSTs (see Appendix 33).

** female assessments may be on either flowers or cones 


\section{SEEDLING SEED ORCHARDS}

A seedlot from a seedling seed orchard containing $n$ families and an average of $t$ trees per family $(t>1)$ can be expected to have a higher $\mathrm{Ne}$ value than a seedlot from a clonal seed orchard with $\mathrm{n}$ families and an average of $\mathrm{t}$ ramets per clone. This is because there is considerable genetic diversity within families, but none within clones. The ratio of the $\mathrm{Ne}$ from a seedling seed orchard with $\mathrm{n}$ families to that of a clonal orchard with $\mathbf{n}$ clones is independent of $\mathbf{n}$, and increases with increasing $\mathbf{t}$. (See example in Table 2 below.)

Table 2. Ne Comparison: open-pollinated seedling seed orchard with $\mathbf{4 0}$ families vs clonal seed orchard with 40 clones*

\begin{tabular}{|l|c|c|c|c|c|c|c|c|c|c|c|}
\hline & \multicolumn{8}{|c|}{ Number of Seedlings per Family or Ramets per Clone (t) } \\
\hline & 1 & 2 & 3 & 4 & 5 & 6 & 7 & 8 & 9 & 10 & Infinite \\
\hline $\begin{array}{l}\text { Ne of o.p. } \\
\text { seedling } \\
\text { orchard }\end{array}$ & 40 & 64 & 80 & 91.6 & 100 & 106.8 & 112 & 116.4 & 120 & 123.2 & 160 \\
\hline $\begin{array}{l}\text { Ne of clonal } \\
\text { orchard }\end{array}$ & 40 & 40 & 40 & 40 & 40 & 40 & 40 & 40 & 40 & 40 & 40 \\
\hline $\begin{array}{l}\text { Ratio of } \\
\text { Ne (seedling } \\
\text { orchard) to } \\
\text { Ne (clonal } \\
\text { orchard) }\end{array}$ & 1.00 & 1.60 & 2.00 & 2.29 & 2.50 & 2.67 & 2.80 & 2.91 & 3.00 & 3.08 & 4.00 \\
\hline
\end{tabular}

*For simplicity, in this example it is assumed that all clones or families have equal numbers of ramets or seedlings, and that all trees are equally productive.

Thus the numbers of trees to be sampled in a seedling seed orchard can be lower than in a clonal orchard, for a given number of families or clones.

If the mean family size in the orchard is less than five trees, sampling requirements are as for clonal orchards (Table 3). If the mean family size exceeds five, sampling requirements are given in Table 4.

Table 3. Sampling requirements for Ne calculations in open-pollinated seedling seed orchards with an average of fewer than five trees per family

\begin{tabular}{|c|c|c|}
\hline Families contributing & Minimum sampling requirement & Genders assessed ** \\
\hline $100+$ & PSTs only & female \\
\hline \multirow{2}{*}{$75-99$} & $15 \%$ including PSTs & male \& female \\
\hline \multirow{2}{*}{$50-74$} & Alternative: $100 \%$ & female \\
\hline $25-49$ & $25 \%$ including PSTs & male \& female \\
\hline$<25$ & Alternative: $100 \%$ & female \\
\cline { 2 - 3 } & $50 \%$ including PSTs & male \& female \\
\hline & $100 \%$ - (all trees) & male \& female \\
\hline
\end{tabular}

\footnotetext{
** female assessments may be on either flowers or cones
} 
Table 4. Sampling requirements for Ne calculations in open-pollinated seedling seed orchards with an average of at least five trees per family

\begin{tabular}{|c|c|c|}
\hline Families contributing & Minimum sampling requirement & Genders assessed ** \\
\hline $50+$ & PSTs only & female \\
\hline \multirow{2}{*}{$37-49$} & $15 \%$ including PSTs & male \& female \\
\hline \multirow{2}{*}{$25-36$} & Alternative: $100 \%$ & female \\
\hline $12-24$ & $25 \%$ including PSTs & male \& female \\
\hline$<12$ & Alternative: $100 \%$ & female \\
\cline { 2 - 3 } & $50 \%$ including PSTs & male \& female \\
\hline
\end{tabular}

** female assessments may be on either flowers or cones 
As instructed by the PTG (PTG 2004 under agenda item \#5 "New Issues") following is a proposal for a system to provide unique identifiers to parent materials selected and collected from prior to implementation of STIA and documented at ATISC. The merit of this is provision of a mechanism for integration into one data base of all Stream 2 parent materials documentation that is intended for use in Stream 2 activities in Alberta and identification in a manner compatible with reporting requirements under standards 25.5, 26.1 and Appendix 25.

The proposal is that:

for all parent materials collected prior to May 1, 2003 and documented at ATISC, a unique identifier will be assigned for each unique genotype as outlined in the standards and Appendix 25. This would allow filling of all compulsory fields and optional fields if desired. The only change to standards in order to accomplish this would be the assignment of a suitable Agency Code. The problem of a suitable Agency Code could be solved by adding "XX" to the agency codes of Appendix 25 and under "Agency Name" identifying this "XX" agency code as "Parent Material Collections made Prior to May 1, 2003". 


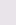


LIBRARY AND ARCHIVES CANADA

Bibliothèque et Archives Canada

I|||||||||||||||||||||||||||||||||||||||||||||||||||||||||||

33286534709023 